\title{
UMIDADE RELATIVA DE EQUILÍBRIO E OXIDAÇÃO DE LIPÍDEOS EM FARINHAS DE CASTANHA DO PARÁ, MACADÂMIA E SOJA
}

\author{
MARCIA SABBAGH
}

Orientador : Prof. Dr. LUIZ GONZAGA DO PRADO FILHO

Dissertação apresentada à Escola Superior de Agricultura "Luiz de Queiroz", da Universidade de São Paulo, para obtenção do título de Mestre em Agronomia - Área de Concentração: Tecnologia de Alimentos.

PIRACICABA

Estado de São Paulo - Brasil

Junho, 1985 
A minha mãe

Aos meus irmãos

DEDICO 
Ao meu irmão Aré́

pelo carinho, compreensão $e$ apoio irrestrito, meu agradecimento especial 


\section{AGRADECIMENTOS}

0 autor agradece a todos que contribuiram direta ou indiretamente para a realização deste trabalho e, em especial, às seguintes pessoas e entidades.

- Ao Prof. Dr. Luiz Gonzaga do Prado Filho, pela segura orientação recebida, sua amizade e seus ensinamentos foram fatores preponderantes para a realização deste trabalho.

- Ao Prof. Dr. Paulo Roberto Cantare1li, pela amizade e apoio durante o trabalho.

- A FAPESP pela bolsa de pesquisa durante o referido trabalho.

- Ao Departamento de Tecnologia Rural da ESALQ-USP pela disposição de seus laboratōrios para que este trabalho pudesse ser realizado. 


\section{INDICE}

LISTA DE FIGURAS $\ldots \ldots \ldots \ldots \ldots \ldots \ldots \ldots \ldots \ldots \ldots \ldots \ldots \ldots \ldots \ldots \ldots$ vii

LISTA DE TABELAS ............................ ix

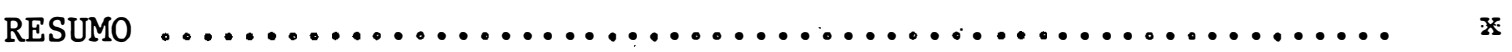

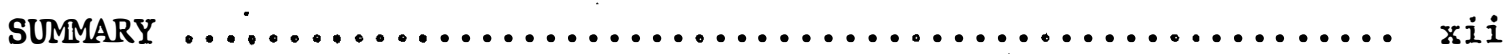

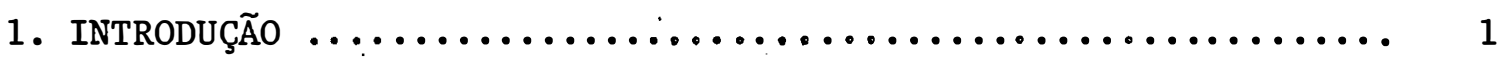

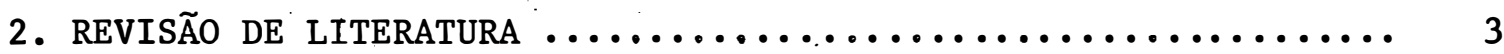

2.1. Sementes 01eaginosas ....................... 3

2.2. Atividades de Āgua e Atividade Enzímica ............. 5

2.3. Atividade da Lipoxigenase em Sementes Oleaginosas ...... 7

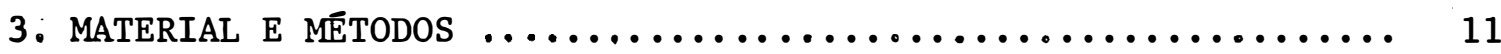

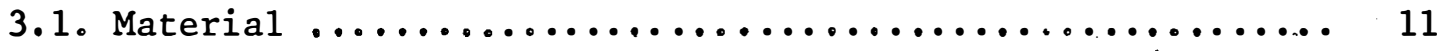

3.1.1. Sementes 0leaginosas $\ldots \ldots \ldots \ldots \ldots \ldots \ldots \ldots \ldots \ldots \ldots \ldots$

3.1.2. Soluções Salinas para Determinação da Umidade Relativa de Equilíbrio ................ 11

3.1.3. Equipamentos Usados para a Determinação da Umidade Relativa de Equilíbrio .............. 12

3.2. Métodos .................................. 19

3.2.1. Preparo das Farinhas ........................... 19

3.2.2. Determinação da Umidade de Equilíbrio nas Farinhas de Sementes 0leaginosas ............ 21

3.2.3. Determinação da Oxidação nas Farinhas ......... 22

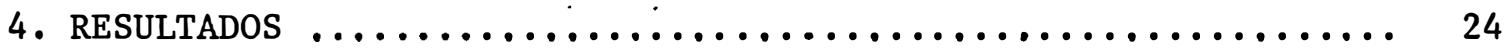

4.1. Preparo das Farinhas .................................. 24

4.2. Determinação da Umidade Relativa de Equilíbrio

nas Farinhas de Sementes Oleaginosas ............... 25 
pagina

4.3. Construção da Isoterma de Absorção ................ 25

4.4. Determinação da 0xidação nas Farinhas ............. 25

5. DISCUSSÃO DOS RESULTADOS ............................. 77

6. CONCLUSÕES $\ldots \ldots \ldots \ldots \ldots \ldots \ldots \ldots \ldots \ldots \ldots \ldots \ldots \ldots \ldots \ldots \ldots \ldots$

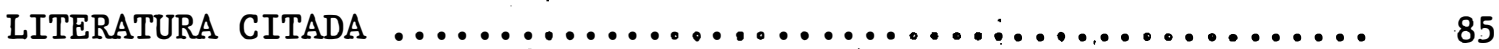

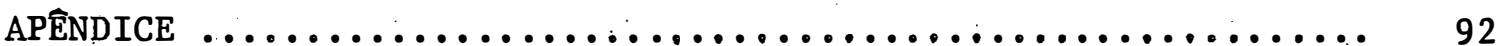


LISTA DE FIGURAS

Figura No

Pagina

1 Equipamento do Método de Ar Não Recirculado .......... 14

2 Câmara em PVC Utilizada para Colocação das Amostras .... 15

3 Equipamento Utilizado no Método Sem Recirculação de ar • 16

4 Equipamento do Método de Ar Recirculado ............. 17

5 Equipamento Utilizado no Método de Ar Recirculado ...... 18

i a 14 Representação Gräfica da Determinação da Umidade Relativa de Equilíbrio de Farinha de Castanha do Parā em Ambientes com $a_{w} 0,51 ; 0 ; 57 ; 0,67 ; 0,75 ; 0,75$ e 0,$81 ;$ a $35^{\circ} \mathrm{C}$ sem e Com Recirculação de $\operatorname{Ar} \ldots \ldots \ldots \ldots \ldots \ldots . \ldots \ldots$.

15 a 23 Representação Gräfica da Determinação da Umidade Relativa de Equilíbrio de Farinha de Macadâmia em ... Ạmbientes com $a_{w} 0,51 ; 0,57 ; 0,67 ; 0,75 ; 0,79$ e 0,$81 ;$ a $35^{\circ} \mathrm{C}$ sem e

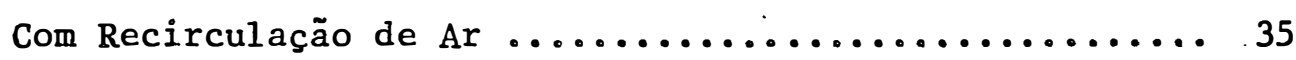

24 a 32 Representação Gräfica da Determinação da Umidade Relativa de Equilíbrio de Farinha de Soja em Ambientes com $a_{w}$ 0,$51 ; 0,57 ; 0,67 ; 0,75 ; 0,79$ e 0,$81 ;$ a $35^{\circ} \mathrm{C}$ sem e Com Re

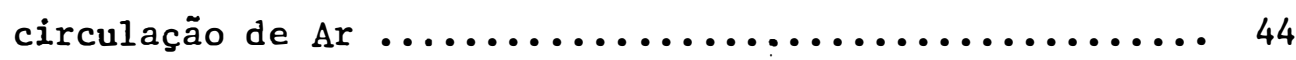

33 e 34 Isoterma de Ábsorção de Farinha de Castanha do Pará. Método Sem e Com Recirculação de Ar ............... 53

35 e 36 Isoterma de Absorção de Farinha de Macadạmia. Método Sem e Com Recirculação de $\operatorname{Ar} \ldots \ldots \ldots \ldots \ldots \ldots \ldots \ldots \ldots \ldots \ldots . \ldots . \ldots . \ldots$ 
37 e 38 Isoterma de Absorção de Farinha de Soja. Método Sem e Com Recirculação de Ar ...................... 57

39 a 44 Representação Grä́ica do Valor Peróxido de Farinha de Castanha do Parā com $a_{w} 0,51 ; 0,57 ; 0,67 ; 0,75 ; 0,79$ e

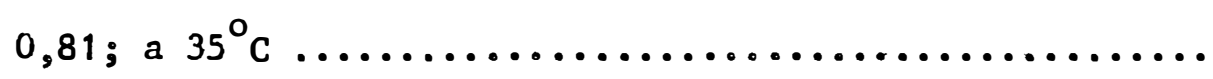

45 a 50 Representação Gräfica do Valor Peróxido de Farinha de Ma cadamia com $a_{w} 0,51 ; 0,57 ; 0,67 ; 0,75 ; 0,79 ; 0,81 ; \quad$ a

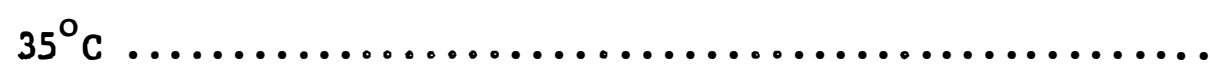

51 a 55 Representação Gráfica do Valor Peróxido de Farinha de So ja com $a_{w} 0,51 ; 0,57 ; 0,67 ; 0,75 ; 0,79$ e 0,$81 ;$ a $35^{\circ} \mathrm{C} .$. 
LISTA DE TABELAS

Tabela No

Pagina

1 Umidade Relativa e Atividade de Āgua de Soluções Salinas Saturadas, à. Temperatura de $35^{\circ} \mathrm{C} \ldots \ldots \ldots \ldots \ldots \ldots . . . .12$

2 Rendimento das Farinhas de Castanha do Pará, Macadâmia e Soja, Variedade Santa Rosa ................... 24 
UMIDADE RELATIVA DE EQUILIBRIO E OXIDAÇÃO DE LIPIDEOS EM FARINHAS DE CASTANHA DO PARĀ, MACADÂMIA E SOJA

Marcia Sabbagh Orientador: Prof.Dr. Luiz Gonzaga do Prado Filho

RESUMO

Considerando o elevado valor protéico das sementes oleaginosas castanha do pará, macadâmia e soja, e a deficiência protéica que normalmente ocorre na dieta de populações menos favorecidas, observouse que o aproveitamento dessas sementes, na forma de farinha desengordurada diretamente na alimentação humana, constitue um meio bastante pró missor de suprir esta deficiência.

Entretanto estas farinhas estao sujeitas a reações químicas oxidativas, durante a armazenagem, que são fortemente influenciadas pelo teor de umidade.

Desta forma, foram estudados dois métodos diferentes parà determinação da umidade relativa de equilíbrio das farinhas, método de ar recirculado e método sem recirculação de ar, e traçadas as isotermas de absorção das farinhas, segundo dados obtidos por estes métodos.

Posteriormente, em função da umidade, foram feitas determinações das reações de autoxidação e oxidação catalisada pela enzima lipoxigenase, nas três farinhas. 
Em valores de atividade de água elevados, $a_{w}=0,75$ no mé todo sem recirculação de ar e $a_{w}=0,84$ no método de ar recirculado, ocor reu perda do material estudado, por deterioração microbiológica antes do aparecimento de qualquer alteração oxidativa.

0 tempo necessārio para obtenção da umidade de equilíbrio nas farinhas, foi bastante reduzido no método de ar recirculado, o que confirmou a eficiência deste método.

Com relação a reações de oxidação de 1 ipideos, observou se em todas as farinhas, um aumento com a atividade de ägua, em reações catalisadas por enzimas. A autoxidação aumentou com a atividade de ảgua até 0,75 , acima deste valor a autoxidação é mais lenta. 
EQUILIBRIUM RELATIVE HUMIDITY AND LIPID OXIDATION IN BRAZIL NUT, MACADÂMIA NUT AND SOYBEAN SEED MEALS

Marcia Sabbagh Adviser: Prof.Dr. Luiz Gonzaga do Prado Filho

SUMMARY

Considering the high protein contents of Castanha do Pará, Macadâmia and Soybean seeds and the proteic deficiency that usualy occours in the diet of underdeveloped populations it was observed that the utilization of such seeds as lipid free meals for human feeding is a very promising source to relive the said deficiency.

However, oxidative reactions may develop during the storage of those seeds which are under strong influence of the humidity contents. There, two diferent methods of determining the equilibrium relative humidity were studied: one utilizing air recycling and the other without air recycling The sorption isoterms were obtained.

Latter on, according to the humidity content the lipid oxidations by chemical and enzymatic reactions were evaluated.

At high water activities, 0.75 for the non air recycling and 0.84 for the air recycling method was observed the occourrence of microbial spoilage before any oxidative changes in the studied meals had occurred. 
The time necessary to reach the equilibrium humidity was shorter for the method using air recyrcling.

In relation to the enzymatic lipid oxidation reactions rate it was observed a positive correlation relation with the increase of activity water values. On the other hand, the autoxidation rates increased up to 0.75 water activity and became slower above this value. 
1. INTRODUÇÃO

A escassez de alimentos de origem animal, principalmente nos países em desenvolvimento leva à necessidade de se obter novas fontes alimentícias, mais baratas e abundantes que as convencionais.

As sementes oleaginosas como a caștanha do pará, a macadâmia e a soja, cujas tortas apresentam apōs a extração do óleo alto teor de proteínas de elevado valor biológico, constituem um meio bastante promissor de suprir, ao menos parcialmente, a deficiência de proteínas que ocorre na dieta da população mundial.

Essas tortas apresentam em sua cọnstituição polissacarídios, lipídios, proteínas, àgua e minerais, que podem durante a armazenagem sofrer alterações de origem microbiana ou química que as levam à perda da qualidade. A obtenção de um produto com boa estabilidade de armazenagem é um fator que tem limitado sua utilização de forma mais ampla.

0 crescimento de microrganismos pode ser controlado atra vés da secagem, levando o produto a um teor de umidade abaixo do seu 
nível crítico, entretanto esses produtos ainda estão sujeitos a reações enzímicas que alteram suas propriedades organoléticas.

Apōs a extração do öleo, na indústria, as farinhas contẻm ainda pequenas quantidades de lipídios, que na presença de umidade suficiente podem oxidar-se, alterando o produto. Eștudos da - interação enzima - conteúdo de umidade, mostram que a velocidade e extensão das reaçoes sao myito dependentes da umidade, servindo esta como um veículo para a enzima e o substrato. Desta forma, em produtos de baixa atividade de ảgua as reações não ocorrem, ou ocorrem muito lentamente.

Com a trituração das sementes, na fabricação das farinhas, a taxa de deterioração é bastante acelerada, porque as enzimas e os respectivos substratos são colocados em contato.

A ação das enzimas sobre as farinhas de castanha do pará, macadâmia e soja tem maior interesse ao observarmos a possibilidade da utilização destas diretamente na alimentação humana, o que exige cuidadosa proteção contra este tipo de deterioração, pois uma vez ocorrida a alteração, torna-se problemātica a recuperação da qualidade perdida.

Entre as enzimas presentes nas sementes oleaginosas, a lipoxigenase, responsāvel pela oxidação de lipídios, è de importância primordial na estabilidade durante a armazenagem.

Desta forma, o trabalho tem por objetivo a determinação das isotermas de absorção de umidade das farinhas de castanha do pará, macadâmia e soja, variedade Santa Rosa, e determinação da oxidação de lipídeos nestas farinhas, em função da atividade de àgua. 
2. REVISÃO DE LITERATURA

\subsection{Sementes 01eaginosas}

Devido ao alto custo da proteína de origem animal, torna-se necessārio que sejam procuradas novas fóntes protéicas mais baratas e abundantes que as convencionais. 0 uso de farinhas de sementes oleaginosas como a castanha do pará, a macadâmia e a soja, pode ser uma forma de suplementação protéica na dieta de populações menos favorecidas.

Considerando o elevado valor protéico da farinha de castanha do parā, MENEZES (1967) observou que seu aproveitamento como subproduto do óleo seria recomendado principalmente em misturas com farinha de trigo, para fabricação de pão misto de maior valor nutritivo.

OLIVEIRA et alii (1980) estudando a composição em aminoácidos da torta obtida da extração do óleo de macadâmia, observaram que esta pode se constituir num subproduto de valor no preparo de rações e mesmo para consumo humano uma vez que apresenta na sua composição todos os aminoācidos essenciais. 
A soja é rica em substâncias lipídicas e protēicas, e com exceção da metionina todos os aminoácidos essenciais estão presentes em ötimas concentrações (SCHMITZ, 1969). Desta forma seus subprodutos derivados: farinha integral ou desengordurada, e o. leite podem participar de alimentos onde a soja entra como principal elemento protéico.

Segundo KELLOR (1974) a farinha de soja desengordurada apresenta algumas vantagens em relação a outros produtos, tais como: é a fonte de proteínas mais econômica e disponível; seu valor nutricional e superior ao dos produtos de soja refinados; e suas propriedades funcionais como absorção de umidade e capacidade de emulsionar gorduras, a tornam ingrediente versátil para alimentos.

(1972) observaram que o teor de açūcares totais e óleo estão diretamente relacionados e que ambos são inversamente proporcionais ao teor de proteínas da semente.

COSTA et alii (1974) pesquisando diferentes variedades de soja com relação aos principais componentes químicos dos grãos, e as qualidades organoléticas e nutricionais de suas respectivas farinhas, concluiram que a variedade Santa Rosa preenche todos os requisitos para ser usada como matéria prima na produção de alimentos.

0 principal fator limitante ao uso de subprodutos de soja na alimentação, segundo SHEMER et alii (1973), é a formação de "off flavor" que ocorre sob tres condições: rompimento celular, disponibilidade de umidade e presença de oxigênio. WILKENS et alii (1967) observaram 
que a inativação da enzima lipoxigenase previne a formação de "off flavor".

\subsection{Atividades de Āgua e Atividade Enzímica}

As sementes oleaginosas são ricas fontes de enzimas, que podem levar a alterações do produto, se āgua suficiente estiver pre sente no alimento.

A água apesar de ser uma molécula simples é de grande im portância na deterioração que ocorre no produto alimentício (KARMAS, 1973), devido às suas propriedades de solvente e reagente.

Em alta umidade, a deterioração de alimentos pode ser causada por processos enzímicos, químicos e microbiológicos (LABUZA et alii, 1970 e 1972). O crescimento microbiano cessa em umidade intermediäria (TROLLER, 1980), valor no qual, entretanto, a atividade enzímica continua, intensa o bastante para exercer efeitos prejudiciais à qualidade do alimento (SCHIMMER, 1980).

E importante para o processamento e armazenagem dos alimentos o estado da água presente. Segundo ROCKLAND (1969), apenas a umidade relativa de equilíbrio não pode refletir precisamente o estado físico químico da água, ou a suscetibilidade de um produto alimentício à deterioração. Condições ótimas de estabilidade são descritas mais precisamente pela combinação da umidade relativa de equilíbrio e umidade total, isto é, pela isoterma de absorção. 
A isoterma de absorção de muitos alimentos exibe uma histerese. Assim, dependendo do ponto de partida da determinação, do estado seco para o úmido ou vice versa pode ser obtido em sistemas de composição de sólidos semelhantes, diferentes teores de umidade (LABUZA, 1968).

Este mesmo autor observou que durante a secagem de um alimento, onde ocorre o abaixamento de $\mathrm{a}_{\mathrm{w}}$, diversos fatores estão envolvidos, tais como: interação āgua solutos, efeito dos capilares do alimento, fenômeno de histerese e interação da água com superfícies ou polímeros de alto peso molecular.

A atividade de água é uma função da isoterma de absorção de um produto alimentício, estando relacionada a um tipo de ligação da água. A primeira parte corresponde a uma camada monomolecular de água adsorvida, de acordo com a teoria de BRUNAUER, EMMETT e TELIER (B.E.T.), e representa uma região de ligação muito firme da āgua, com grupos polares da superfície do adsorvente. A parte ascendente da isoterma reflete o acúmulo progressivo de água menos ligada, aos finos capilares da estrutura dos alimentos (POTTHAST et alii, 1975).

De acordo com LABUZA (19̣80 e 1982), quando um produto alimentício ganha umidade acima do valor B.E.T., ocorre um aumento na ta xa de reações químicas e enzímicas que podem levā-los a perda da qualidade. Para cada aumento de 0,1 na atividade de água, a taxa de muitas dessas reações duplica ou triplica. 
ROCKLAND e NISHI (1980) demonstraram que em alimentos a reatividade de cada componente é influenciada por sua afinidade pelas moléculas de àgua e pela competividade entre grupos químicos hidrofílicos e hidrofóbicos, sendo, portanto, também influenciada pela arquitetura química estrutural do sistema. Desta forma as propriedades de um sistema são influenciadas tanto pela energia de ligação da água a grupos moleculares específicos, como pelas interações entre constituintes químicos hidrofílicos.

ACKER (1969) observou que a isoterma de absorção pode predizer quais reações ocorreriam no sistema. Na região de pura adsorçao, isto é, abaixo do ponto de inflexão da isoterma, alterações enzímicas não ocorrem ou ocorrem muito lentamente. A imobilização da água previne a difusão do substrato até a enzima.

0 efeito da atividade de água sobre a cinética e atividade das enzimas foi revisado por DRAPON (1972). As reações foram por ele estudadas em sistema modelo, em função da atividade de água do sistema, e mostram que a ação das enzimas em sistemas com baixo teor de umidade são diferentes daqueles observados em soluções ou dispersões.

\subsection{Atividade da Lipoxigenase em Sementes Oleaginosas}

ACKER (1962), em pesquisas sobre a atividade enzímica em alimentos de baixa umidade, observou que em sementes oleaginosas as rea ções que ocorrem abaixo do nível crítico, isto é, em uma umidade tal que o crescimento de microrganismos é impossível, são hidrolise das 
gorduras com a formação de ācidos graxos livres, e oxidação de lipídeos. Foi demonstrado que tais reações são devidas à ação das enzimas lipase e lipoxigenase.

Estudos de CAVALETó et alii (1966) sobre o efeito da umi dade, calor e luz sobre a estabilidade das sementes cruas de macadâmia, demonstraram que a estabilidade das mesmas decresce com o aumento da umidade e temperatura de armazenagem.

De acordo com GARDNER (1975) óleos e gorduras polinsaturados oxidam, formando hidroperóxidos (produto inicial da oxidação) e causando a deterioração de alimentos caracterizada por "off flavor", toxidez e diminuição no teor de nutrientes. Em muitos produtos vegetais a presença da enzima lipoxigenase prëdetermina a formação de hidroperóxidos, especialmente se a integridade celular é rompida mecânicamente.

A prevenção de sabores e odores estranhos, relacionados a oxidação de lipídeos, é de grande importância para aceitação da farinha de soja pelo consumidor. A inativação da enzima lipoxigenase, atra vés de tratamento térmico, é essencial no processamento (ZANGELMI et alii, s.d.).

A maior causa da deterioração "off flavor" no processamento de sementes de macadâmia, é devido ao ranço oxidativo. GRIMWOOD (1971) observou que esta deterioração è parcialmente devido a enzimas, que devem ser eliminadas durante o processamento térmico. Para obtenção de máxima vida ūtil, uma relação satisfatōria de tempo e temperatura, 
acoplado a técnicas de acondicionamento que excluem $0_{2}$, deve ser utilizada.

Pesquisas de PRICHAVADHI e YAMAMOTO (1965) evidenciaram que a secagem das sementes de macadâmia à temperatura de $68^{\circ} \mathrm{C}$ não afeta a atividade enzímica, responsável por alterações das gorduras, durante a armazenagem em altas temperaturas e altas umidades.

Em estudos para prevenir a oxidação de lipídeos em "carne de soja", MUSTAKAS et alii (1969), observaram que tratamento térmico feito por calor seco à temperatura de $85,7^{\circ} \mathrm{C}$ inativou a 1 ipoxigenase e melhorou a estabilidade, apresentando o produto "flavor" agradável após dois anos de armazenagem. O calor ūmido tambēm è um tratamento efetivo, embora quando precedido por calor seco a $68^{\circ} \mathrm{C}$, resulte em baixa estabilidade e "flavor" inferior.

GOLDOUSKII e IVANOVA (1979) pesquisaram o efeito da 1ipoxigenase em sementes de soja; em diferentes teores de umidade e obser varam que estas enzimas foram ativadas apenas quando o teor de umidade estava ao redor de $13 \%$. Desta forma a secagem dos grãos a $9 \%$ de umidade tem um efeito protetor sobre a estabilidade, diminuindo as perdas do produto durante a armazenagem.

Segundo MEYER (1975) os óleos e gorduras utilizam $0_{2}$ len tamente por certo período, no qual não è possível detectar o "flavor" dos produtos do ranço, este período é chamado período de indução e é seguido por um segundo período, onde a tomada de $0_{2}$ é muito mais rápida, posteriormente a taxa de oxidação diminue outra vez. 0 tempo de 
cada período é função do tipo de gordura e os fatores que influem nesta reaçao, podem ser: temperatura, umidade, quantidade de $\mathrm{O}_{2}$ disponível, luz e presença ou ausência de antioxidantes e próoxidantes.

BROCKMAN e ACKER (1977a) observaram que na soja, em ambiente.seco, a lipoxigenase ataca não apenas o ácido linolêico livre, mas tambēm os que fazem parte das moléculas de triglicerídeos e fosfatídeos. Relataram também que a livre mobilidade dos ácidos graxos e triglicerídeos torna a presença da āgua não essencial. .

Em pesquisas sobre a oxidação enzímica de lipídeos, em sistemas de baixa umidade BROCKMAN e ACKER (1977b) demonstraram que durante o processo de oxidação, o ácido linolêico é transformado em produtos polares com aumento do peso molecular e do teor de oxigênio.

QUAST e KAREL (1972) pesquisaram o efeito da umidade relativa sobre a taxa de oxidação e observaram que em estágios iniciais de oxidação e em baixa umidade a taxa é fortemente influenciada pela umidade relativa de equilíbrio, entretanto, com o progresso da reação, a taxa torna-se independente da umidade. Estes mesmos autores observaram que em UR elevadas, a taxa aumenta consideravelmente, possivelmente devido a um aumento na mobilidade dos reagentes.

0 estudo da deterioração oxidativa de lipídeos em alimentos secos, feito por ASAKAWA e MATSUSHITA (1978), utilizando sistema modelo com umidades relativas baixa (0\%), média (48\%) e alta (83\%), demonstrou que em umidade intermediäria ocorrem maiores perdas. 
3. MATERIAL E METODOS

\subsection{Materia1.}

\subsubsection{Sementes Oleaginosas}

As sementes oleaginosas utilizadas para a execução do presente trabalho, tiveram as seguintes procedências: castanha do parā, adquirida em estabelecimento comercial; macadâmia, cedida pelo Instituto Agronômico de Campinas, Estação Experimental de Tietê; e soja, variedade Santa Rosa, oriunda do Instituto Agronômico de Campinas e cedida pelo Prof. Dr. Rodolpho de Camargo, do Departamento de Tecnologia Rural da ESALQ.

3.1.2. Soluções Salinas para Determinação da Umidade Relativa de Equilíbrio

A determinação da umidade relativa de equilíbrio nas amostras foi feita através de métodos que utilizam o borbulhamento do ar em soluções salinas saturadas, com subsequente passagem sobré as 
amostras das farinhas. A Tabela 1 relaciona uma série de sais e as res pectivas atividades de água de suas soluções, à temperatura de $\quad 35^{\circ} \mathrm{C}$ (SMITH, 1971).

Tabela 1. Umidade Relativa e Atividade de Água de Soluções Salinas Saturadas, à Temperatura de $35^{\circ} \mathrm{C}$

\begin{tabular}{lcc}
\hline Solução Salina & Umidade Relativa \% & Atividade de Água \\
\hline Nitrato de Magnésio & 51 & 0,51 \\
Brometo de Sódio & 57 & 0,57 \\
Cloreto de Cobre & 67 & 0,67 \\
Cloreto de Sódio & 75 & 0,75 \\
Sulfato de Amônio & 79 & 0,79 \\
Brometo de Potássio & 81 & 0,81 \\
Cloreto de Potássio & 84 & 0,84 \\
Nitrato de Potássio & 91 & 0,91 \\
\hline
\end{tabular}

FONTE : SMITH (1971).

3.1.3. Equipamentos Usạdos para a Determinação da Umidade Relativa de Equilíbrio

Neste item foi descrita a montagem dos equipamentos uti lizados para a determinação da umidade relativa de equilî́brio nas farinhas de sementes oleaginosas. 
3.1.3.1. Equipamento do Método de Ar Não Recirculado

Este equipamento consta de um filtro de água e óleo, pro vido de um manômetro que permite a regulagem da pressão e, portanto, da vazão; três garrafas lavadoras contendo respectivamente ägua destilada, solução salina saturada e 1ã de vidro; uma câmara que contém as amostras, feita em tubo PVC com $10 \mathrm{~cm}$ de diâmetro, e funciona em sistema de prateleiras. Cada câmara comporta quatro prateleiras onde são postas as placas com as farinhas a serem equilibradas (Figuras 1 e 2).

0 ar vindo do compressor passa pelo filtro que regula a pressão a 1,6 Kgf $/ \mathrm{cm}^{2}$, pelas garrafas lavadoras e pela camara, onde flue em sentido ascendente, saindo desta por um orifício situado na tampa. Todo o sistema funciona dentro de uma estufa que mantém a tempe ratura de $35^{\circ} \pm .1^{\circ} \mathrm{C}$ (Figura 3 ).

3.1.3.2. Equipamento do Método de Ar. Recirculado

Este equipamento consta de uma bomba peristāltica; duas garrafas lavadoras contendo respectivamente água destilada e solução salina saturada, exatamente no local de saída do ar da garrafa de solução salina, foi colocado lã de vidro para evitar o arraste de partículas de solução para as amostras; e uma câmara com as amostras, igual a do equipamento anterior (Figuras 4 e 5).

0 ar impulsionado pela bomba peristáltica passa pelas garrafas lavadoras, pela câmara contendo as amostras e daí, via bomba peristāltica, repete o ciclo. 


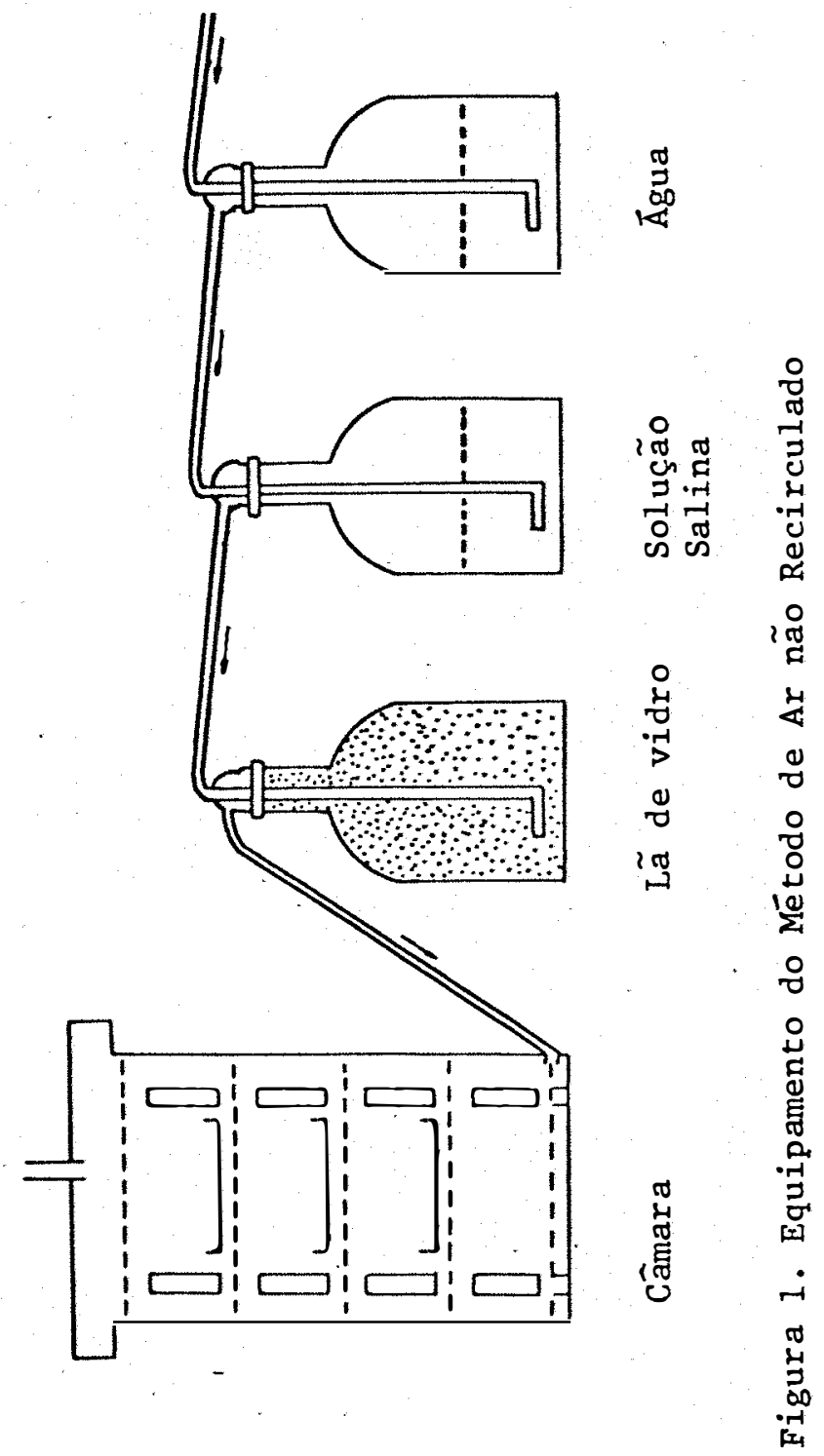




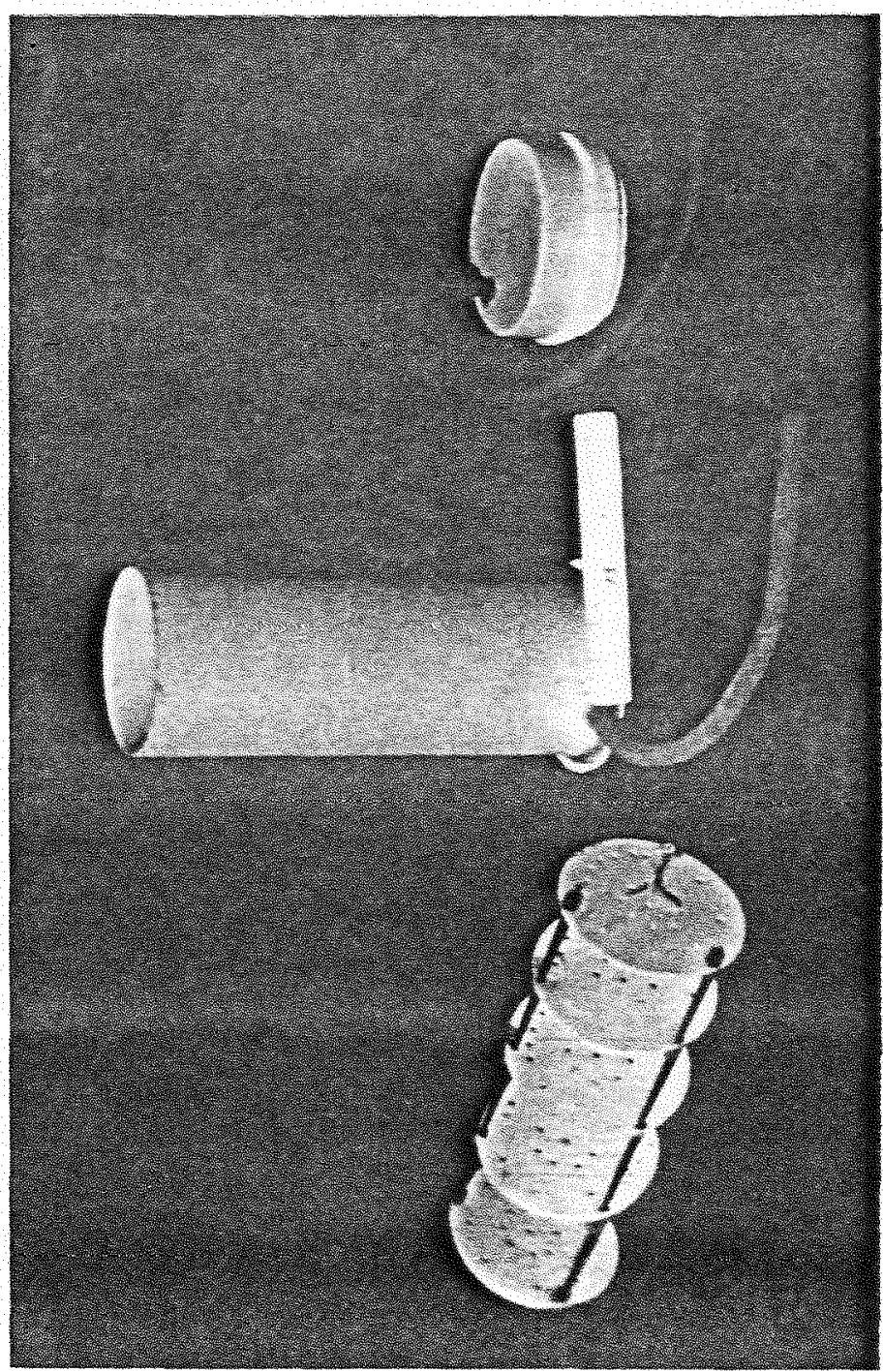

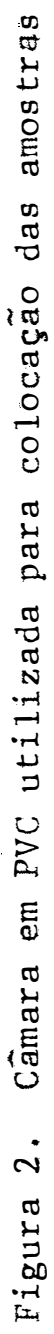




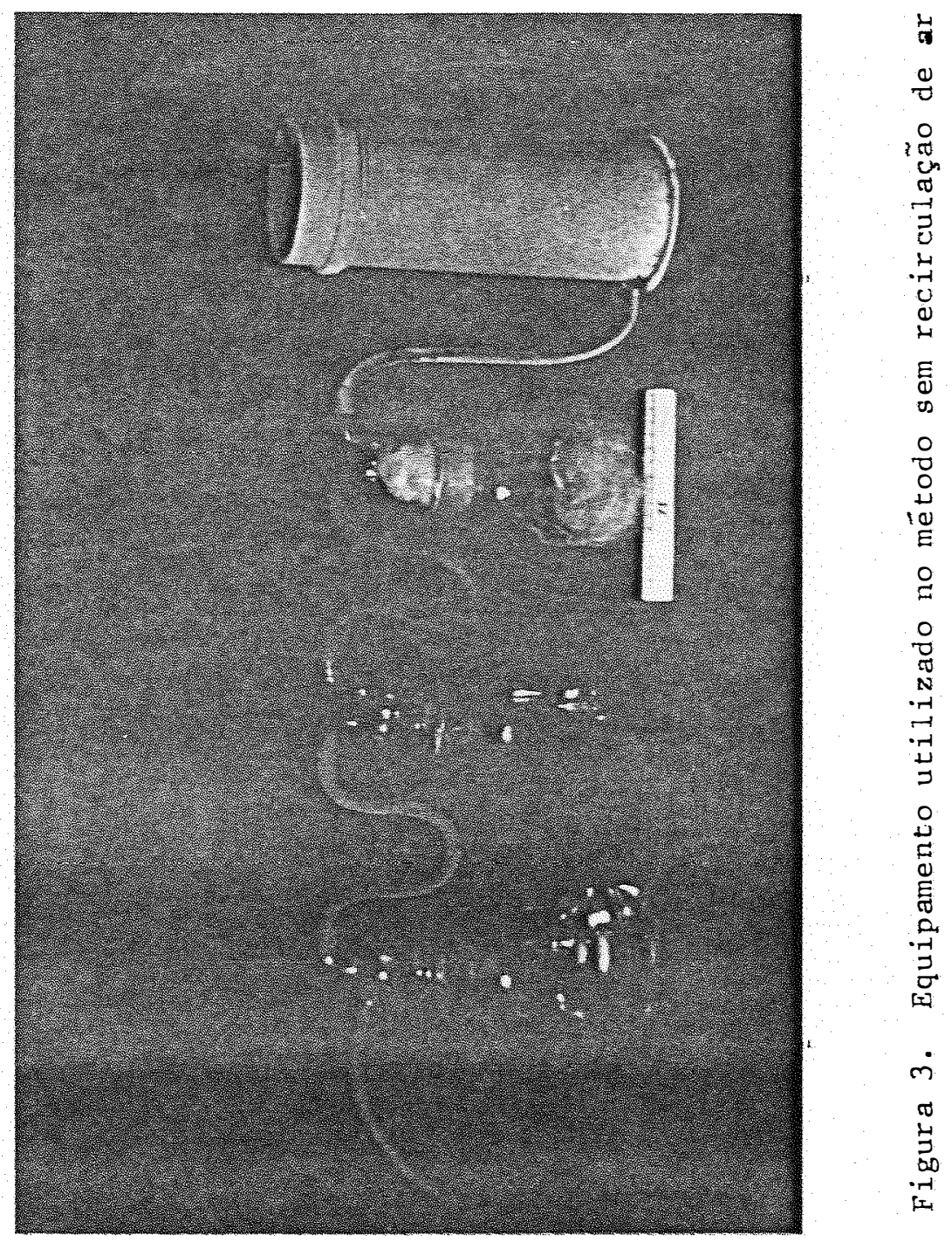




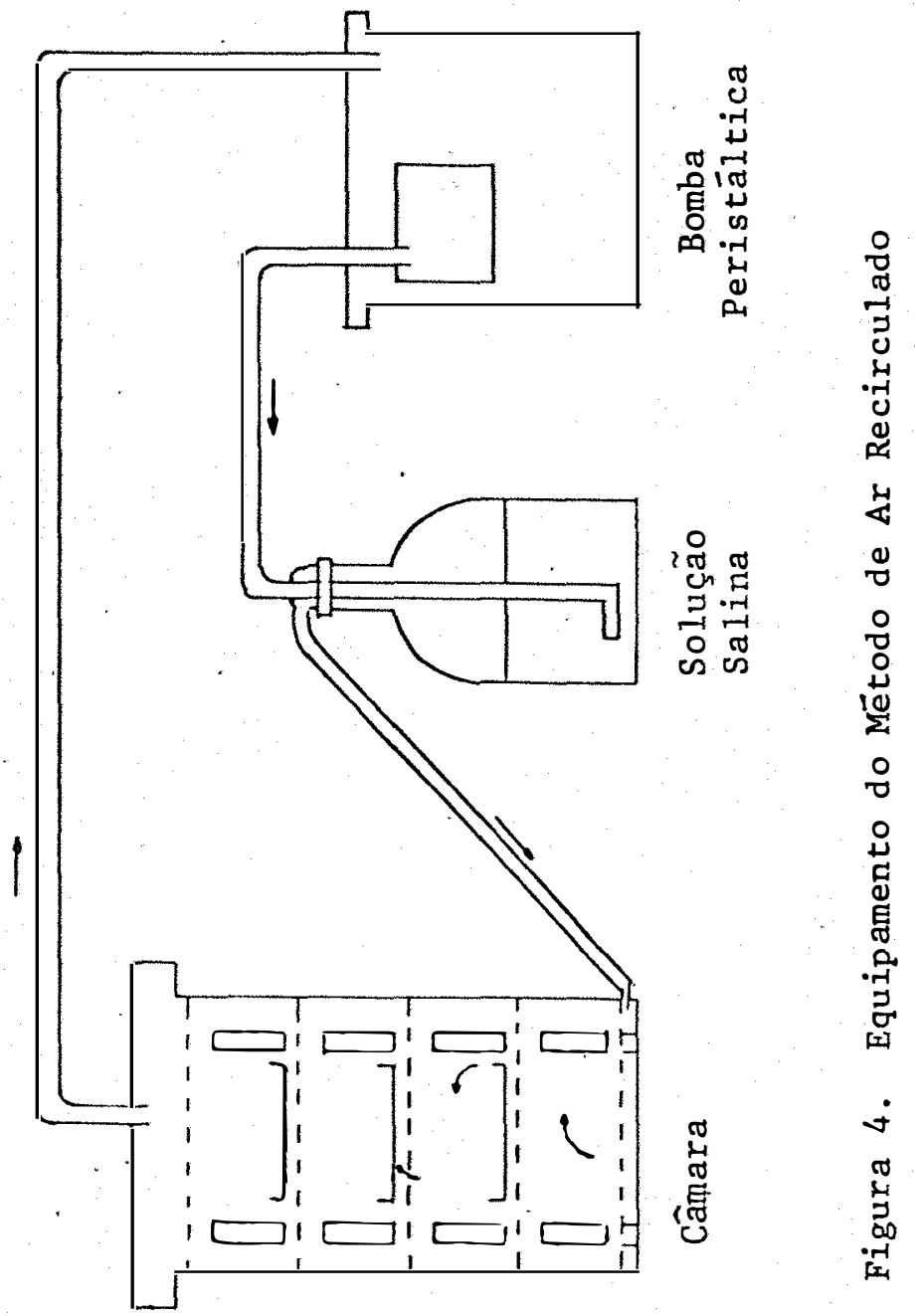




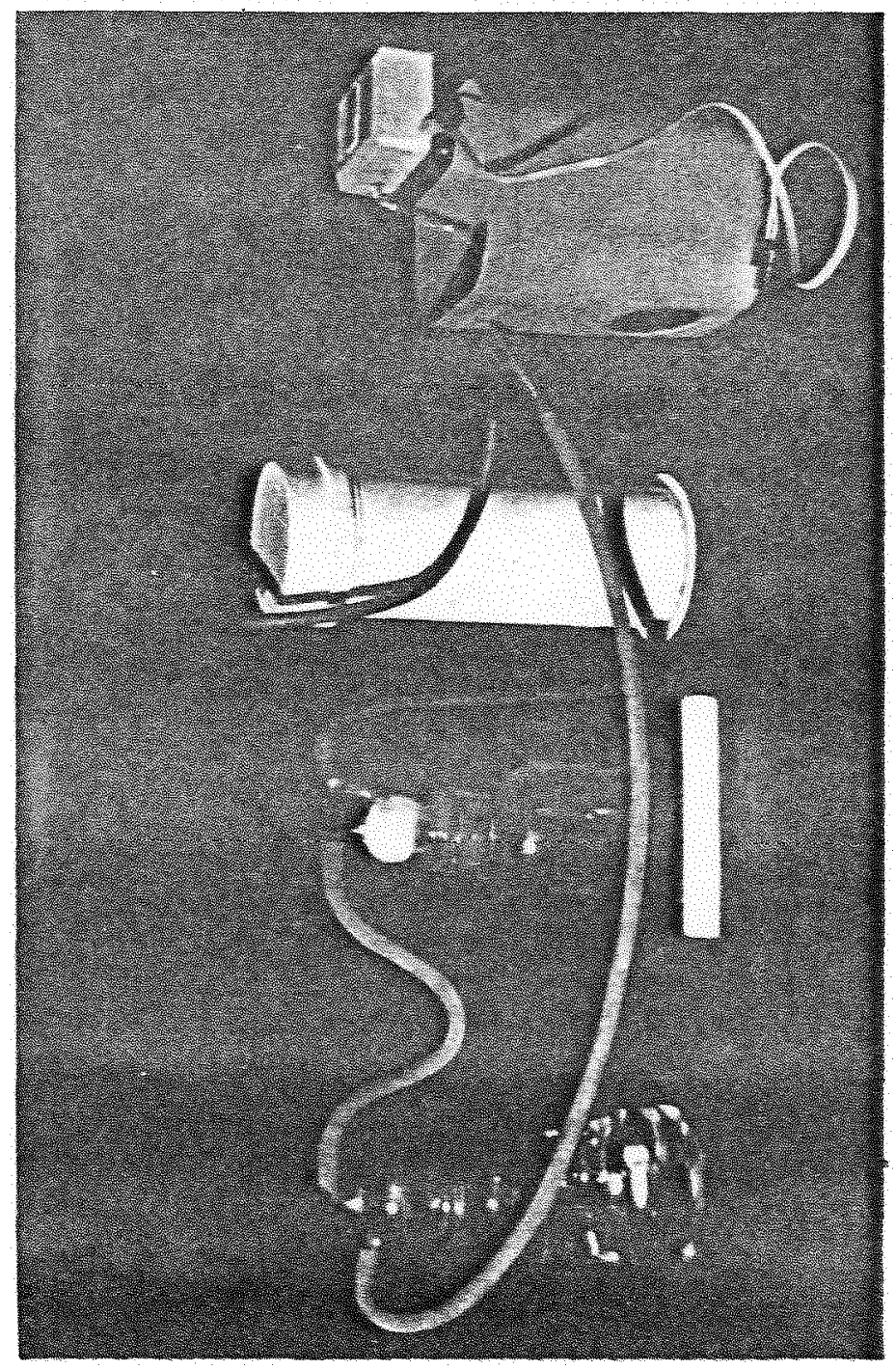

O 


\subsection{Métodos}

\subsubsection{Preparo das Farinhas}

3.2.1.1. Farinhas de Castanha do Parā e Macadâmia

As sementes de castanha do parā e macadâmia, foram inicialmente selecionadas, quebradas e separadas das cascas manualmente, de pois trituradas para facilitar a extração do ōleo. Esta trituração não foi muito intensa, para evitar a formação de uma pasta que poderia dificultar a operação de prensagem, uma vez que estas sementes são macias e muito ricas em óleo.

A extração do óleo foi feita empregando a mesma técnica us ada na indústria, isto é, um processo misto expressão - dissolventes. No primeiro estágio, a prensa hidrāulica extrai o óleo virgem, à seguir as tortas ainda ricas em óleo foram desintegradas e submetidas a ação do solvente éter de petṛöleo, fração $30-40^{\circ} \mathrm{C}$, no extrator de saxhlet, por um período de cinco horas.

Depois de preparadas as farinhas passaram por um processo de padronização, através de uma peneira com malha de 20 Mesh, obtendo-se desta forma uma farinha fina e uniforme. 
Fluxograma do Processo de Fabricação das Farinhas de castanha.do parā de macadâmia .

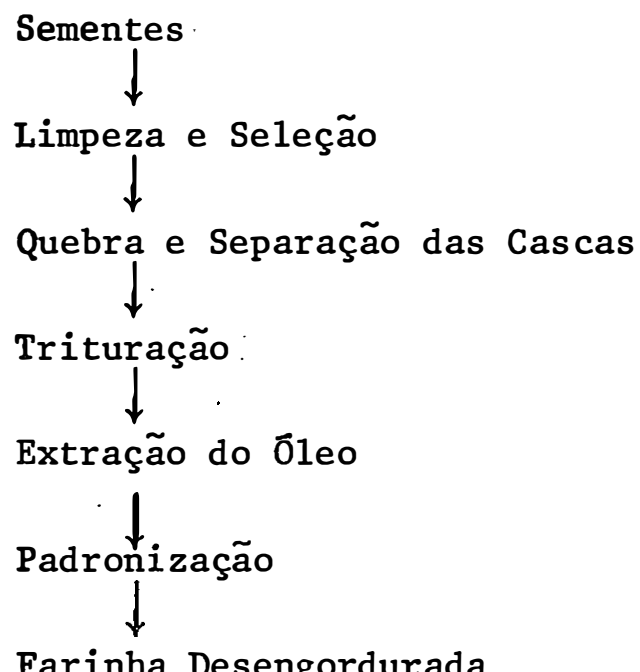

3.2.1.2. Farinha de soja

o preparo da farinha de soja foi executado conforme o esquema apresentado por KELLOR (1974). As sementes de soja foram selecionadas, quebradas, descascadas, e trituradas para facilitar a extração do óleo, por éter de petróleo, fração $30-40^{\circ} \mathrm{C}$, no extrator de Soxhlet, por um período de 18 horas.

A farinha assim obtida foi submetida a tratamento térmico (calor úmido) a $100^{\circ} \mathrm{C}$ por 30 minutos, para inativação dos fatores antinutricionais (SMITH e CIRCLE, 1972). A umidade absorvida neste tra tamento foi eliminada através de secagem em estufa de ar circulante à $35^{\circ} \mathrm{C}$ por 5 horas.

Os flocos resultantes desse processo passaram por nova moagem e padronização, através de uma peneira com malha de 20 mesh. 
Fluxograma do Processo de Fabricação da Farinha de Soja

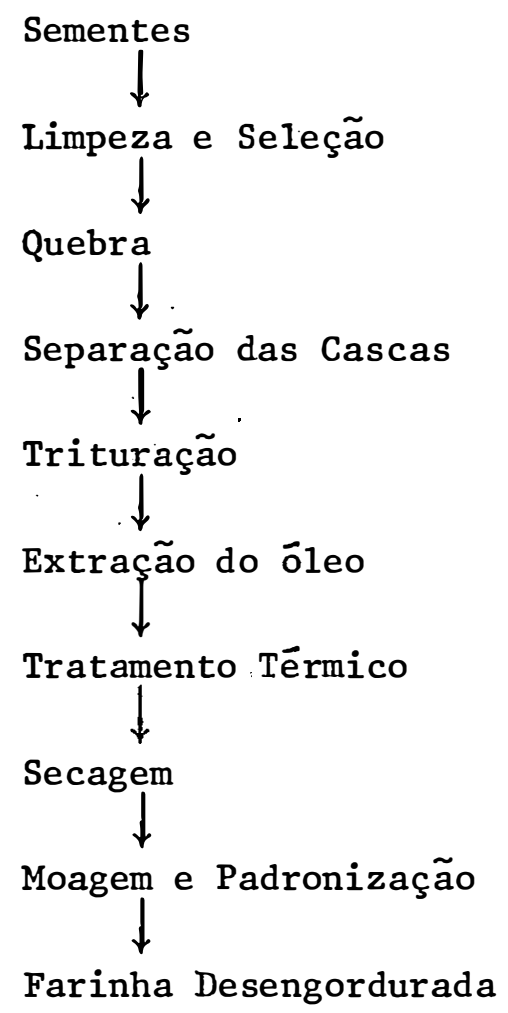

3.2.2. Determinação da Umidade de Equilíbrio nas Farinhas de Sementes 0leaginosas

3.2.2.1. Método Sem Recirculação de Ar

Esse método foi baseado naquele descrito por LONCIN et alii (1968), com algumas simplificações, utilizando o dispositivo descrito no item 3.1.3.1. Nele quatro amostras de farinha de Castanha do Parā (3 gramas), Macadâmia (3 gramas) ou Soja ( 4 gramas), foram colocadas na câmara. 
0 experimento foi iniciado ligando-se o compressor, que inicia a passagem do ar por todo o sistema. Em intervalos de 12 horas, as amostras foram pesadas e o experimento foi considerado terminado quando o peso das amostras permaneceu constante, porque o equilíbrio da umidade entre as amostras e a solução foi alcançado.

Depois de obtido o equilíbrio as amostras foram secas à vácuo (pressão residual 80 Torr), à temperatura de $60^{\circ} \mathrm{C}$ por cinco horas, sendo então determinado o peso seco.

A cada pesagem a posição das amostras na câmara foi modificada, para que o fluxo de ar em cada uma delas fosse uniforme.

\subsubsection{Método de Ar Recirculado}

Este método foi uma adaptação simplificada do método proposto por GAL (1975), e utilizou o equipamento descrito no item 3.1.3.2., com recirculação de ar, sendo as pesagens feitas em intervalos de 6 horas.

3.2.3. Determinação da Oxidação nas Farinhas

A dẹterminação da oxidação nas farinhas foi feita segundo o método colorimétrico descrito por STINE et alii (1954), com modificações no processo de extração da gordura, o que foi feito com uma mistura de benzeno-metanol, na mesma proporçã் utilizada no método.

Para um estudo comparativo entre a autoxidação e a oxidação catalisada por enzimas, eram feitos dois experimentos paralelos. 
Amostras "in natura" e amostras submetidas a tratamento térmico a $110^{\circ} \mathrm{C}$ por 120 minutos, para inativação enzímica (ACKER e WISSE, 1972), foram equilibradas com as soluções salinas, pelo método de ar recirculado, pa ra obtenção da $a_{w}$ desejada nas mesmas. Depois de obtido o equilíbrio, era adicionado óleo de soja comercial às amostras de farinhas, obtendo-se um teor final de $20 \%$ de óleo. Neste momento foi feita a primeira determinação do valor peróxido.

Em seguida, as amostras foram armazenadas nas $a_{w}$ correspondentes, à $35^{\circ} \mathrm{C}$, e em intervalos de 24 horas foram feitas determinações do valor peróxido, para acompanhar o desenvolvimento da oxidação. 
4. RESULTADOS

4.1. Preparo das Farinhas,

No preparo das farinhas de castanha do parā, macadâmia

e soja, foram observados os resultados mostrados na Tabela 2, com relação ao rendimento de cada uma das farinhas.

Tabela 2. Rendimento das Farinhas de Castanha do Parā, Macadâmia e Soja, Variedade Santa Rosa

\begin{tabular}{lccc}
\hline & $\begin{array}{c}\text { Castanha } \\
\text { do Parā }\end{array}$ & Macadâmia & Soja \\
\hline Amostra Inicial. & $2000 \mathrm{~g}$ & $3000 \mathrm{~g}$ & $1000 \mathrm{~g}$ \\
Sementes descascadas & $700 \mathrm{~g}$ & $800 \mathrm{~g}$ & $710 \mathrm{~g}$ \\
O1eo & $400 \mathrm{~m} 1$ & $450 \mathrm{~m} 1$ & $200 \mathrm{~m} 1$ \\
Farinha desengordurada & $195 \mathrm{~g}$ & $145 \mathrm{~g}$ & $500 \mathrm{~g}$ \\
\hline
\end{tabular}


4.2. Determinação da Umidade Relativa de Equilíbrio nas Farinhas de Sementes Oleaginosas.

Com base na determinação do peso da materia seca foi ca1 culado o teor de umidade das farinhas $\left(\mathrm{gH}_{2} \mathrm{O} / 100 \mathrm{~g}\right.$ M.S.). Os resultados obtidos em experimentos com os métodos sem e com recirculação de ar podem ser observados nas Figuras 6 a 32 .

4.3. Construção da Isoterma de Absorção.

A constrụção da isoterma de absorção foi feita utilizando valores médios da umidade das farinhas, após estas atingirem peso constante, ou seja a umidade relativa de equilíbrio.

As Figuras 33 a 38 mostram a isoterma de absorção das farinhas de sementes oleaginosas, nas $a_{w}$ relacionadas na tabela 1 do item 3.1 .2 .

4.4. Determinação da Oxidação nas Farinhas

Os resultados obtidos neste experimento podem ser observados nas Figuras 39 a 56. 


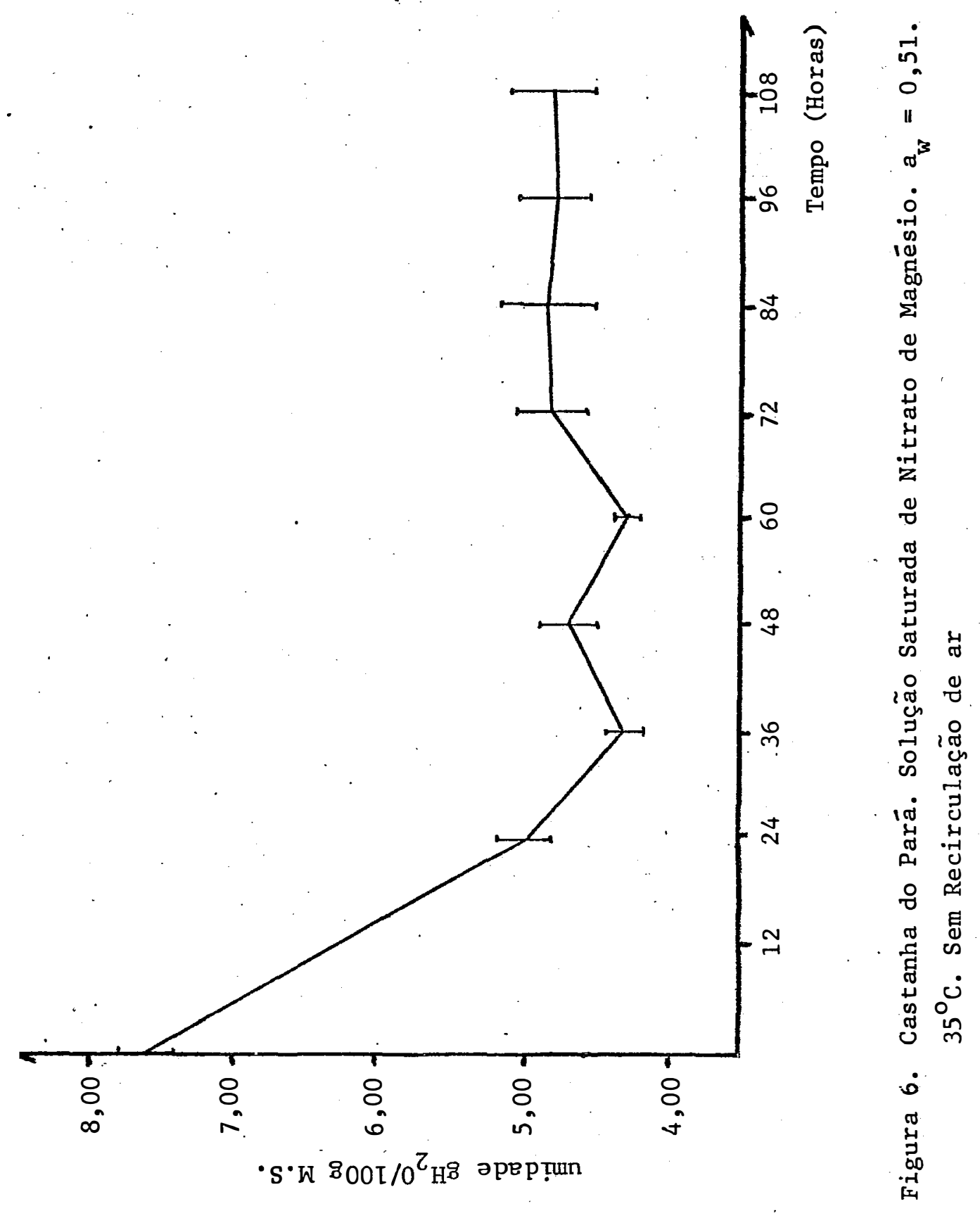




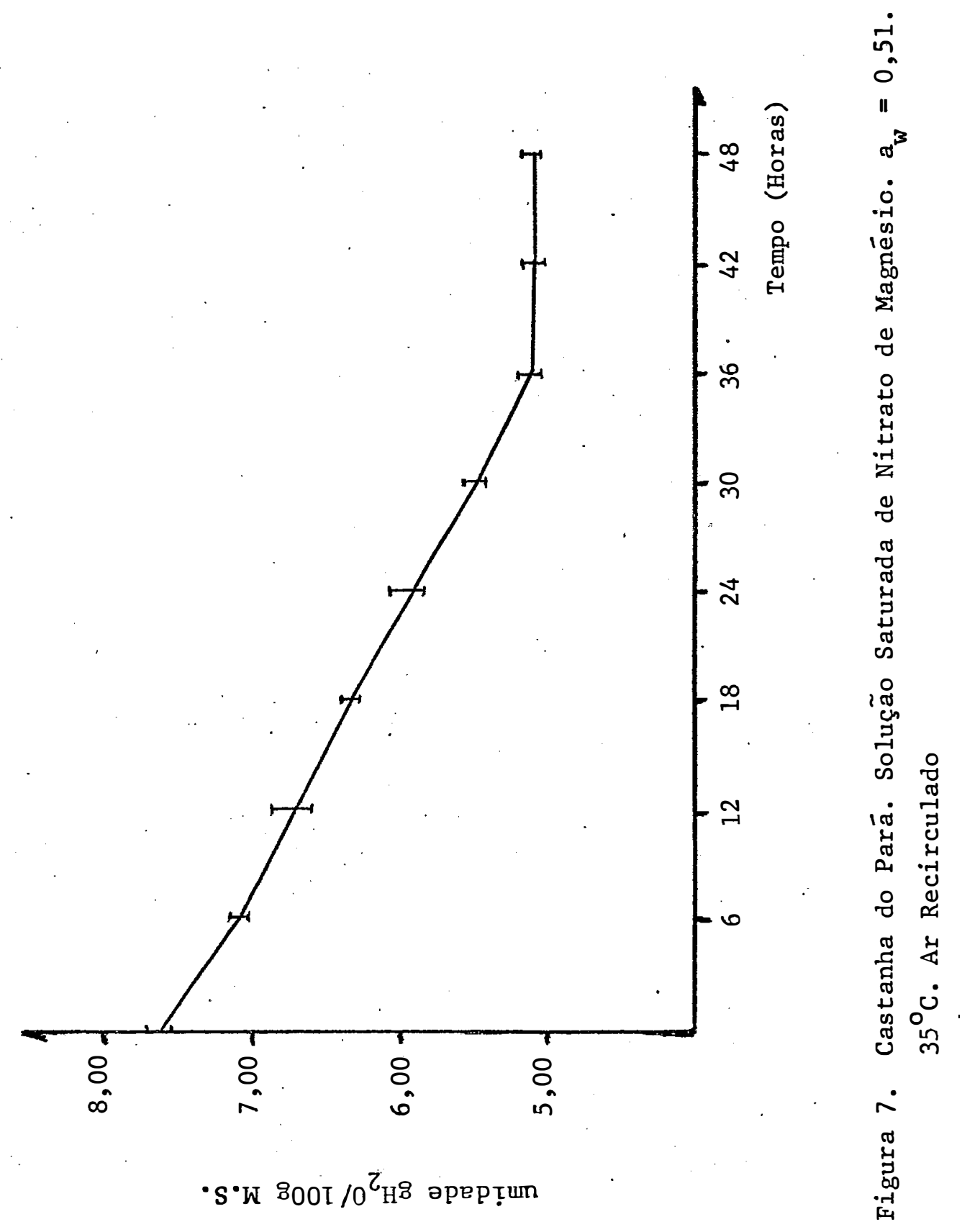




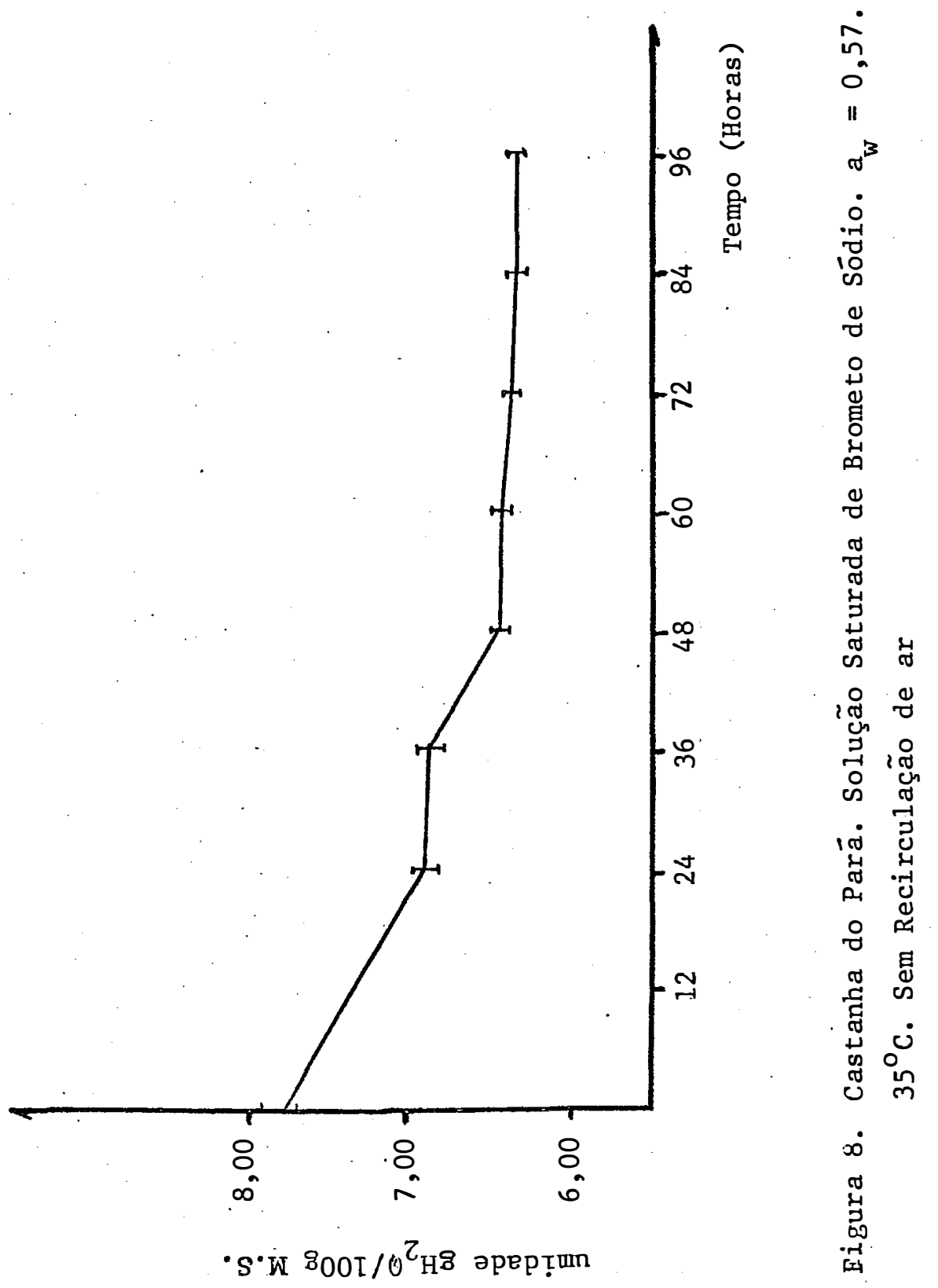




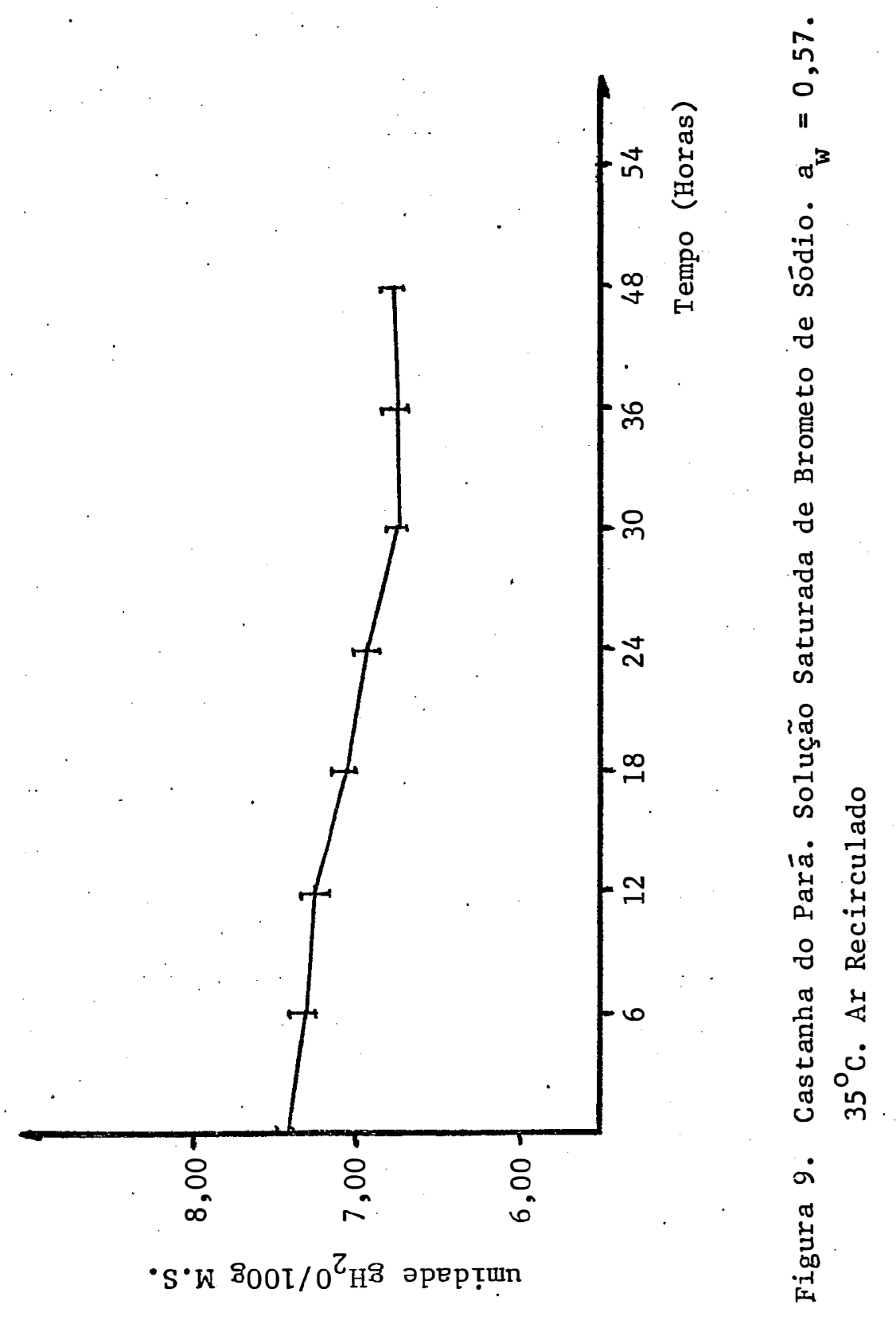




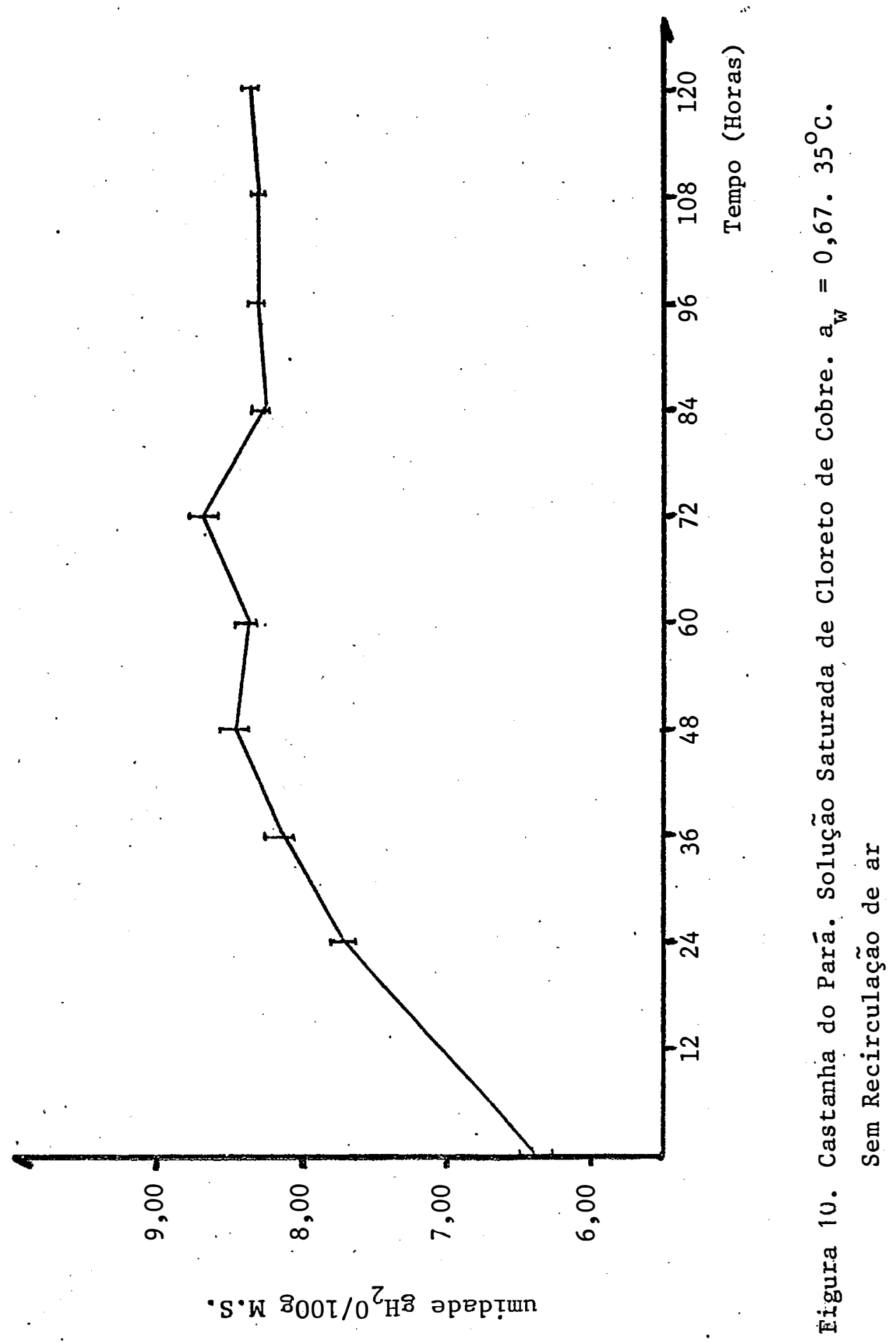




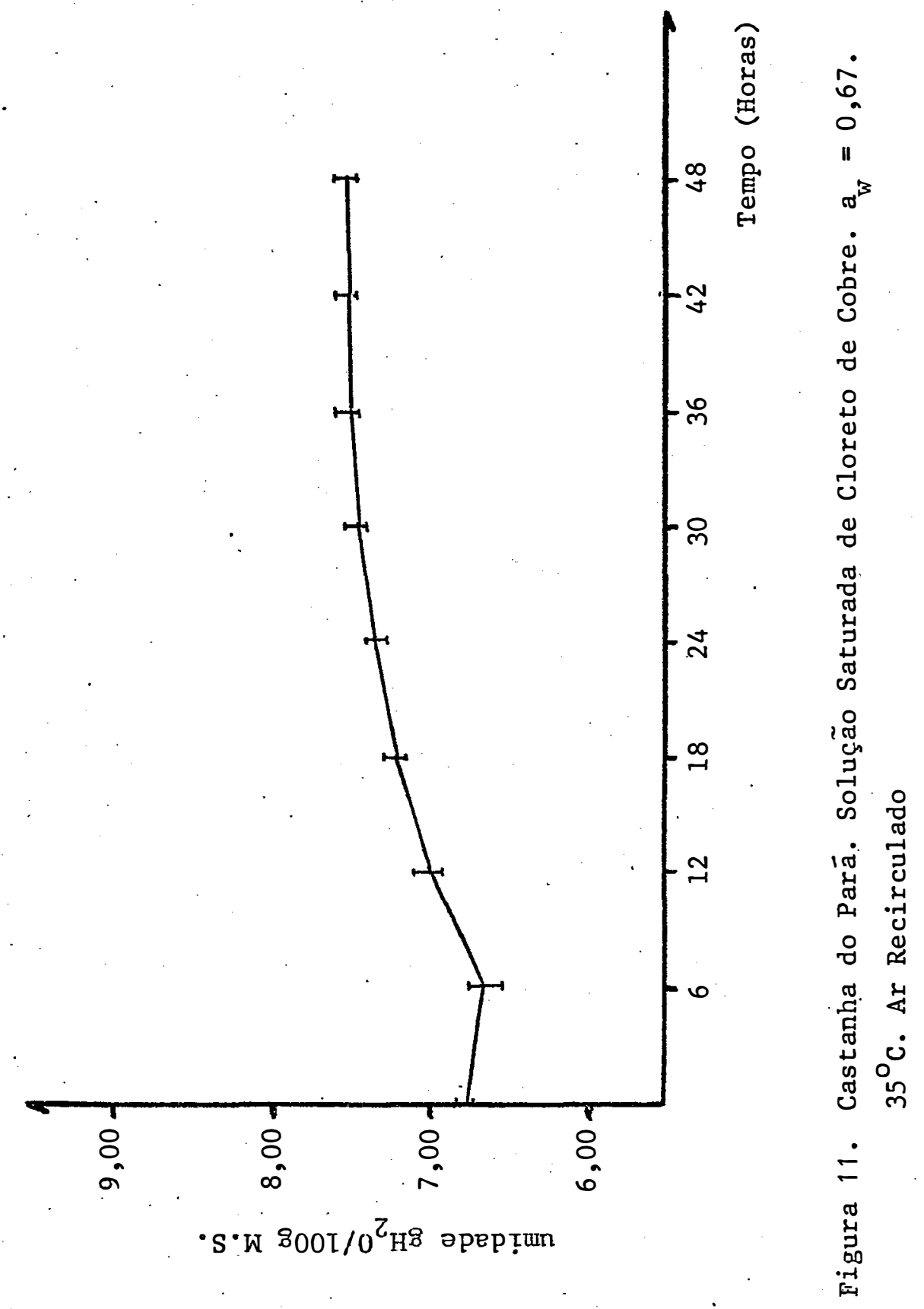




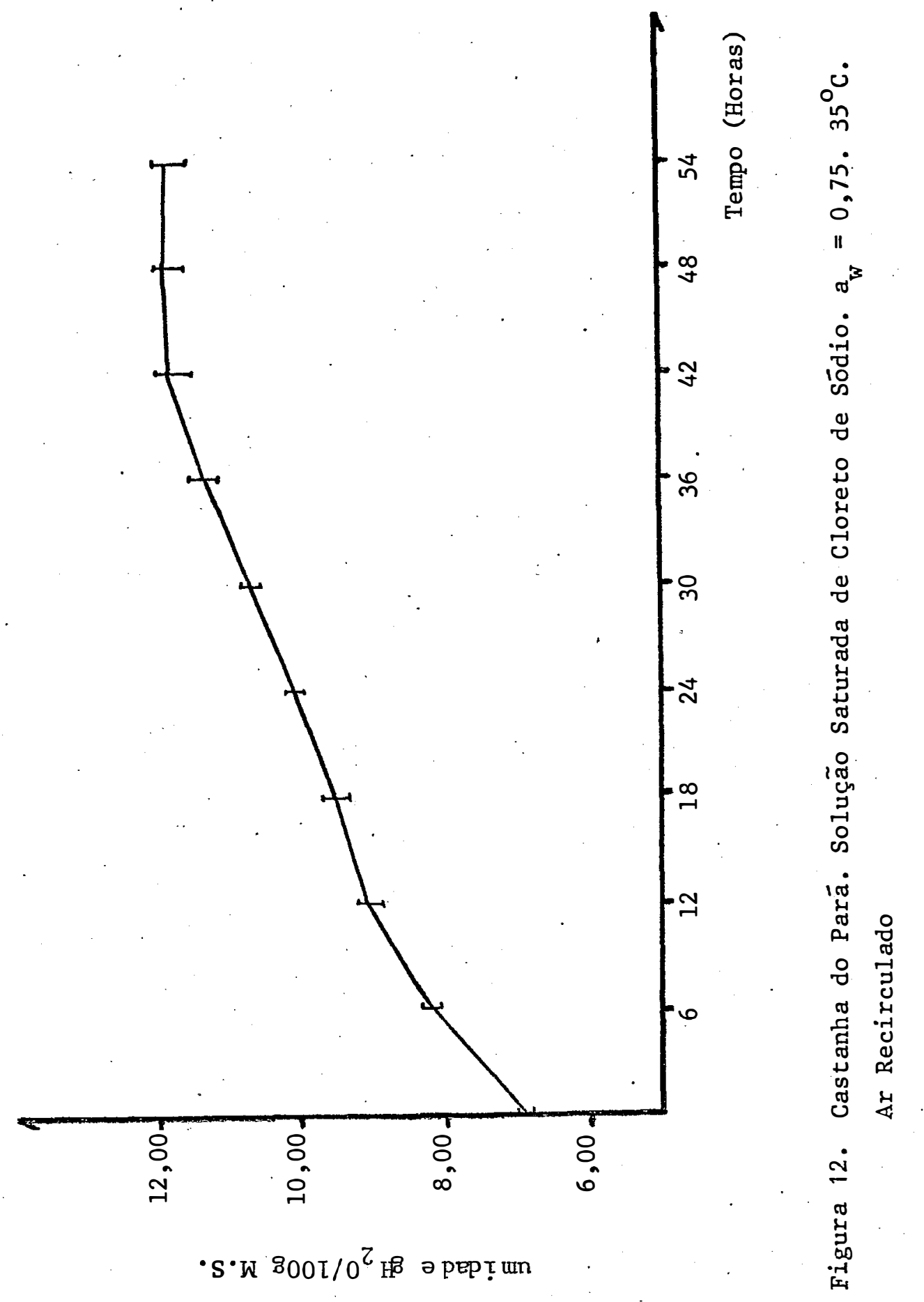




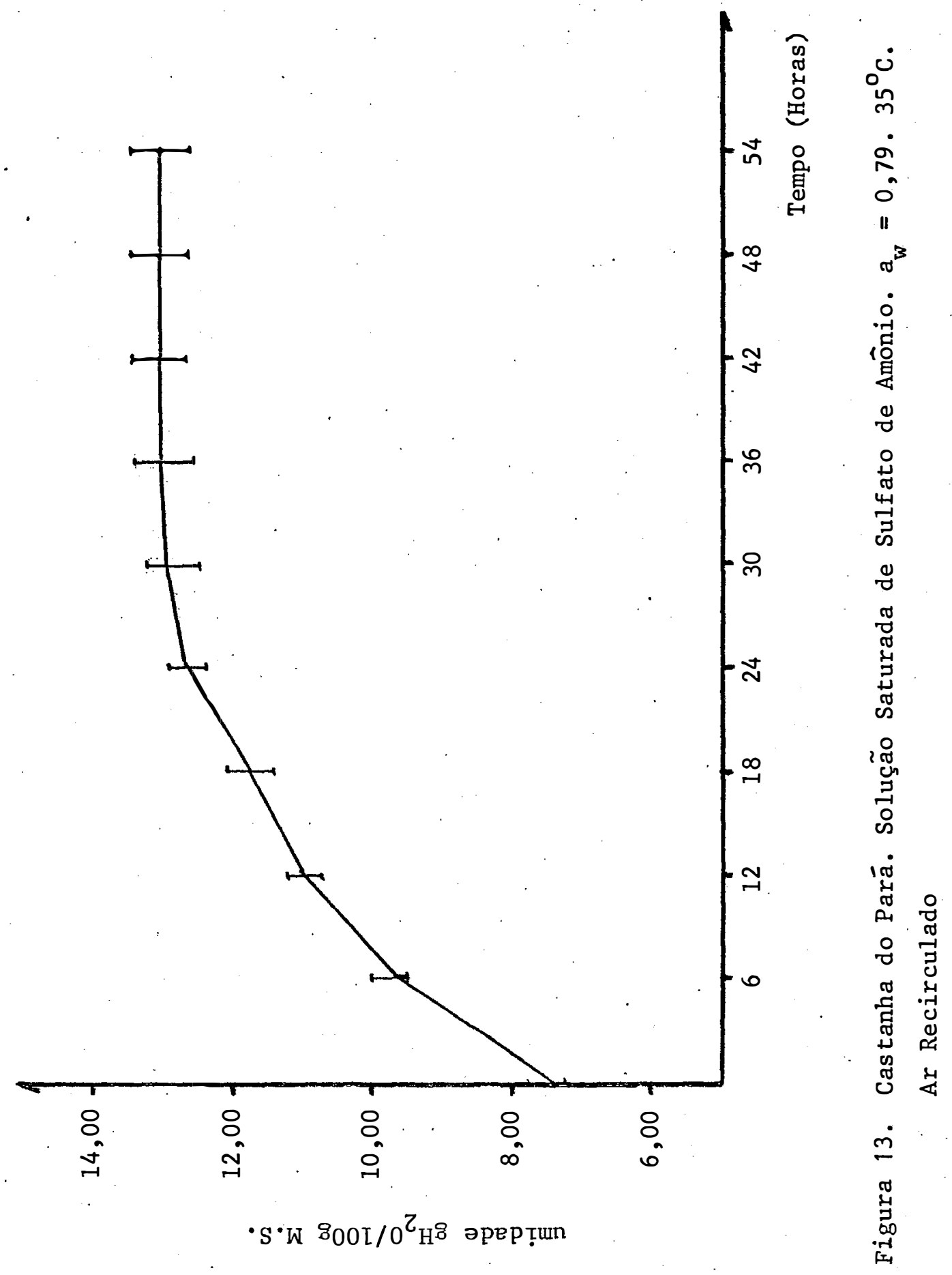




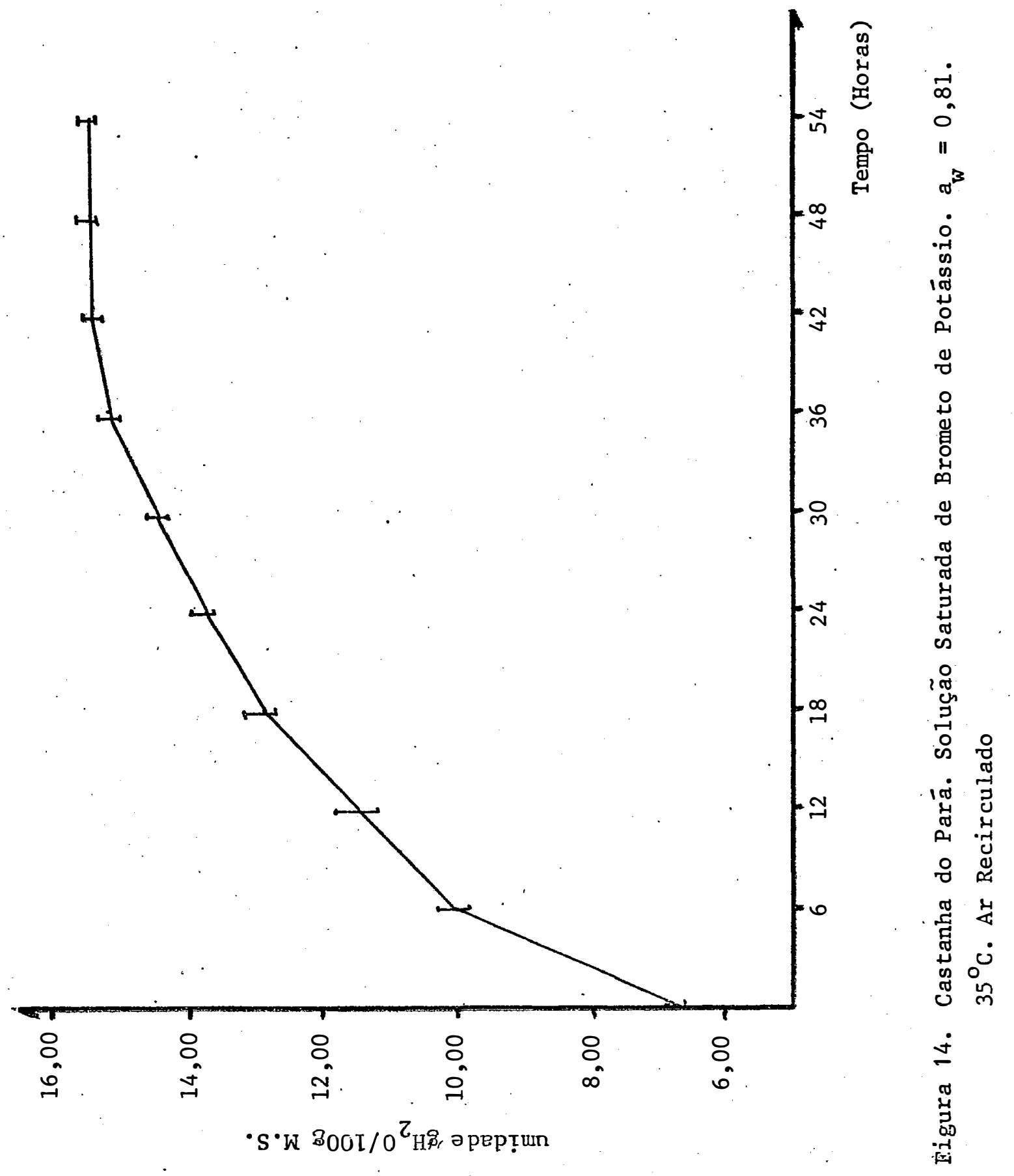




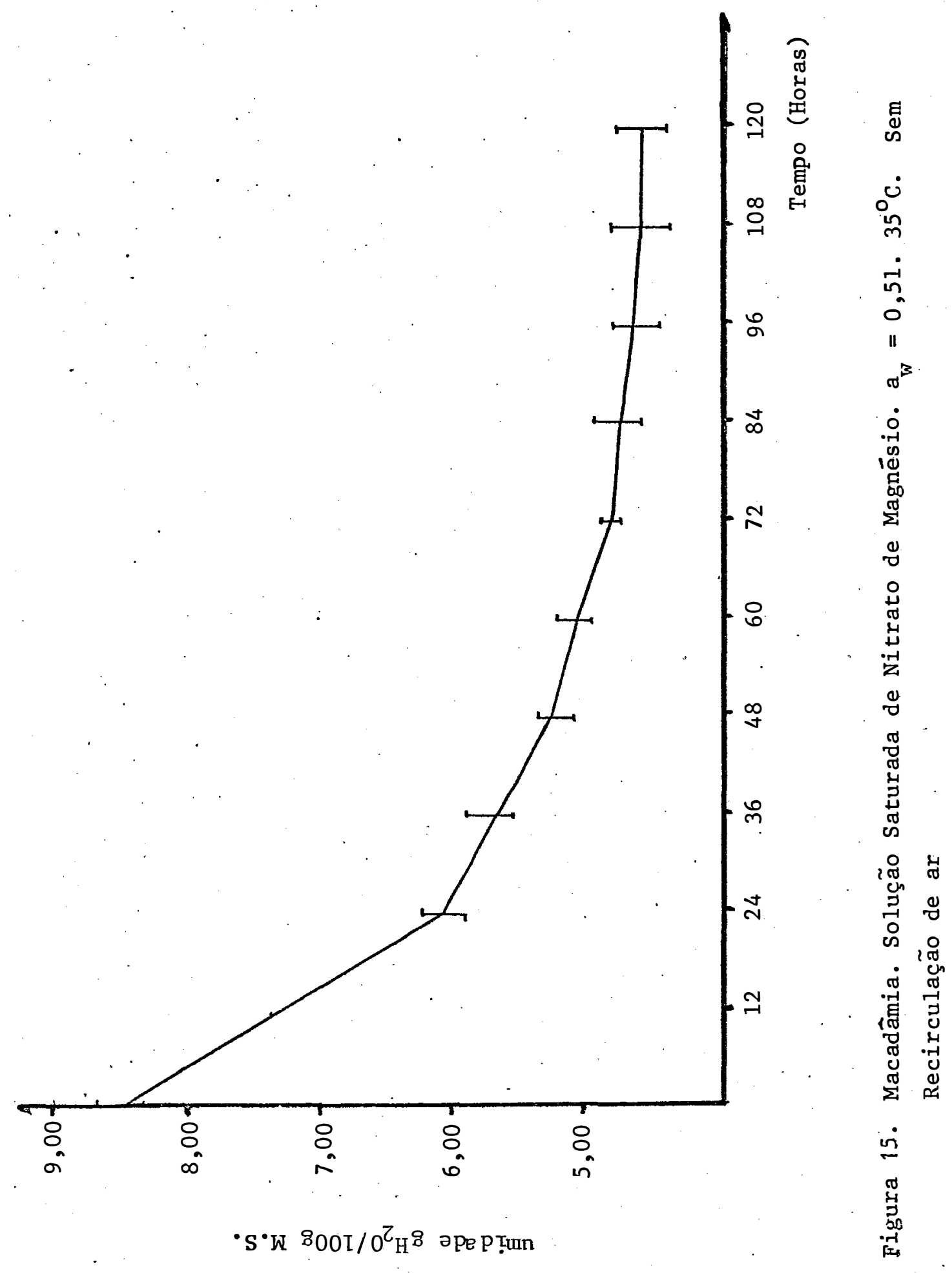




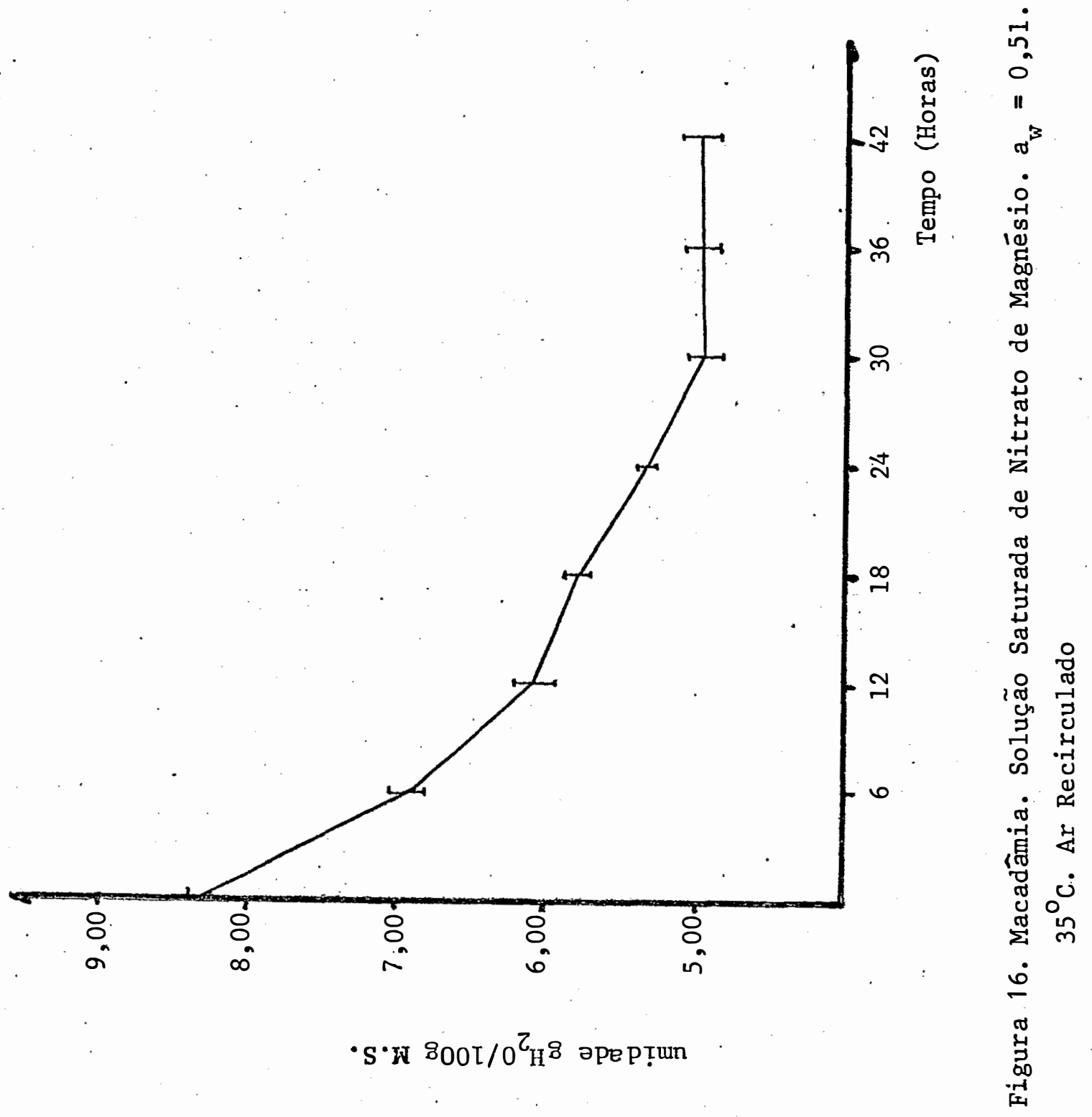




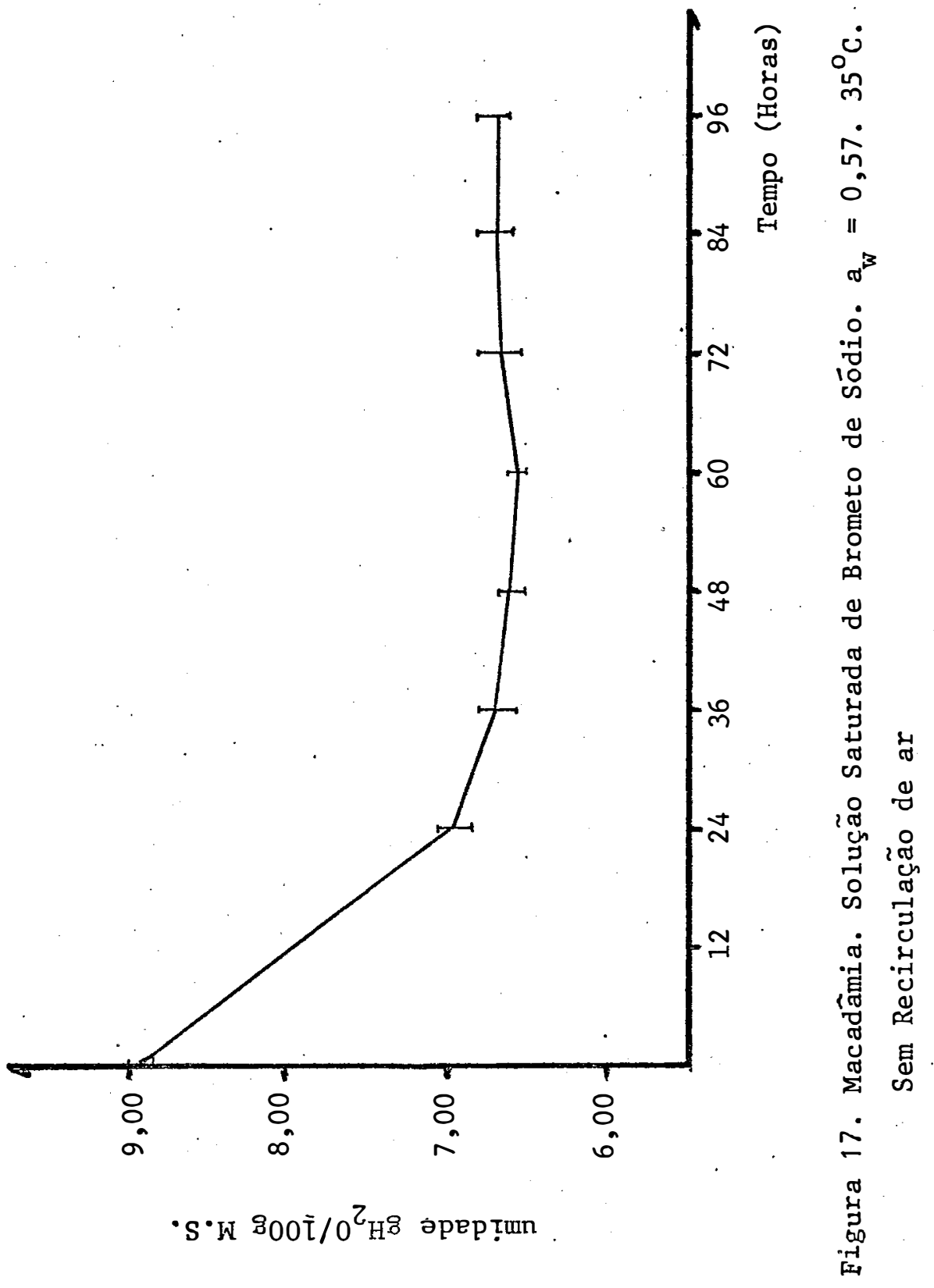




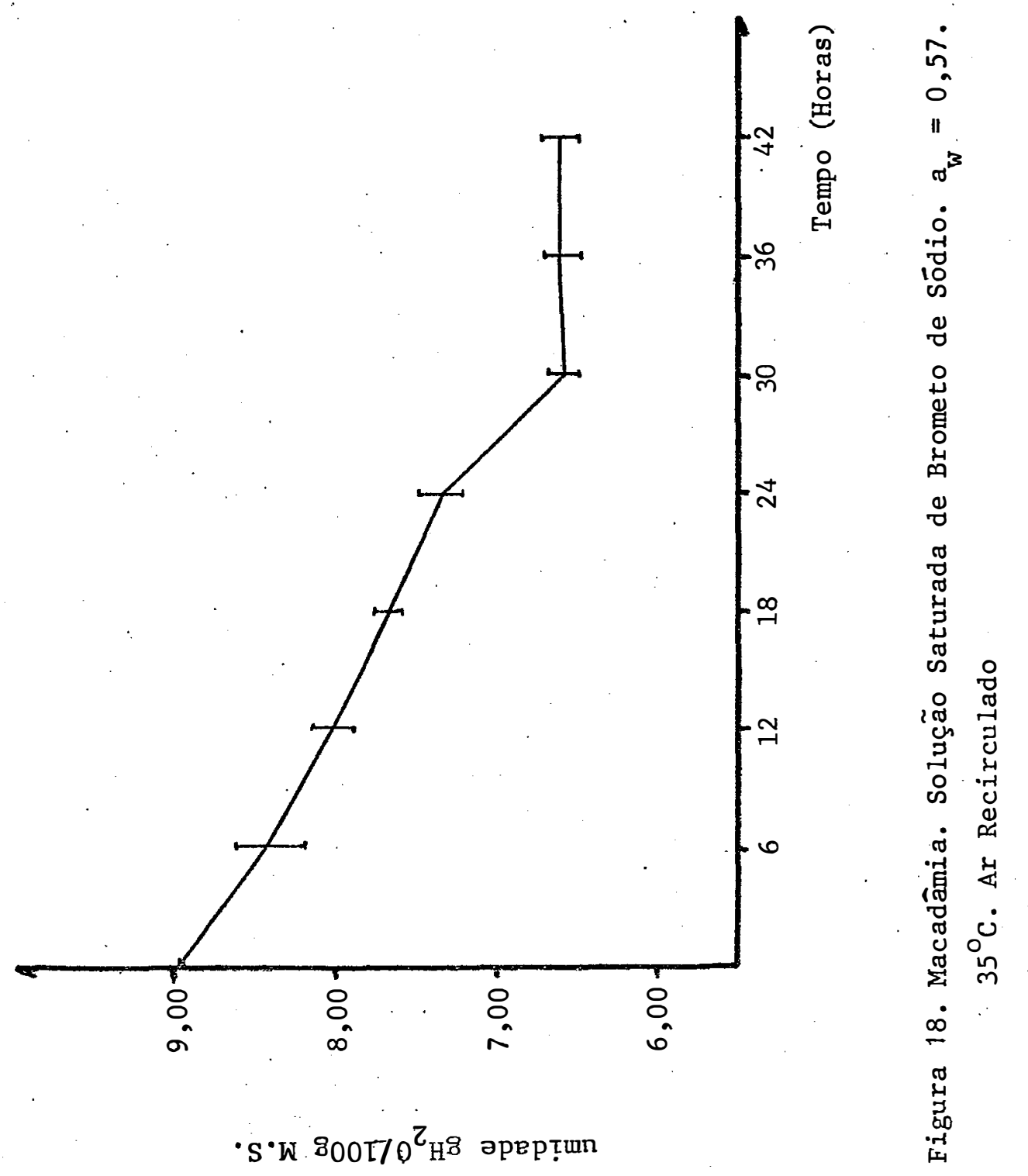




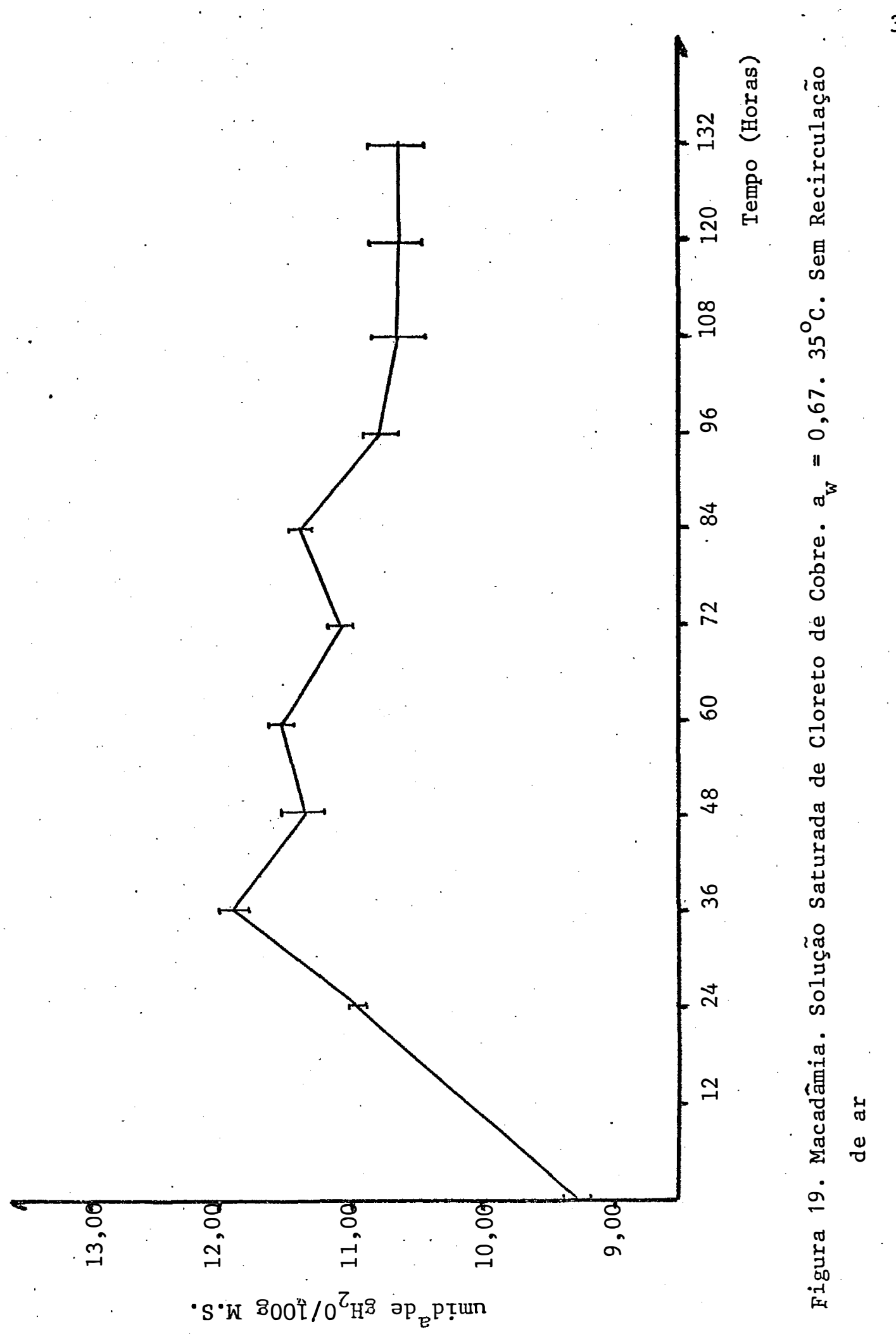




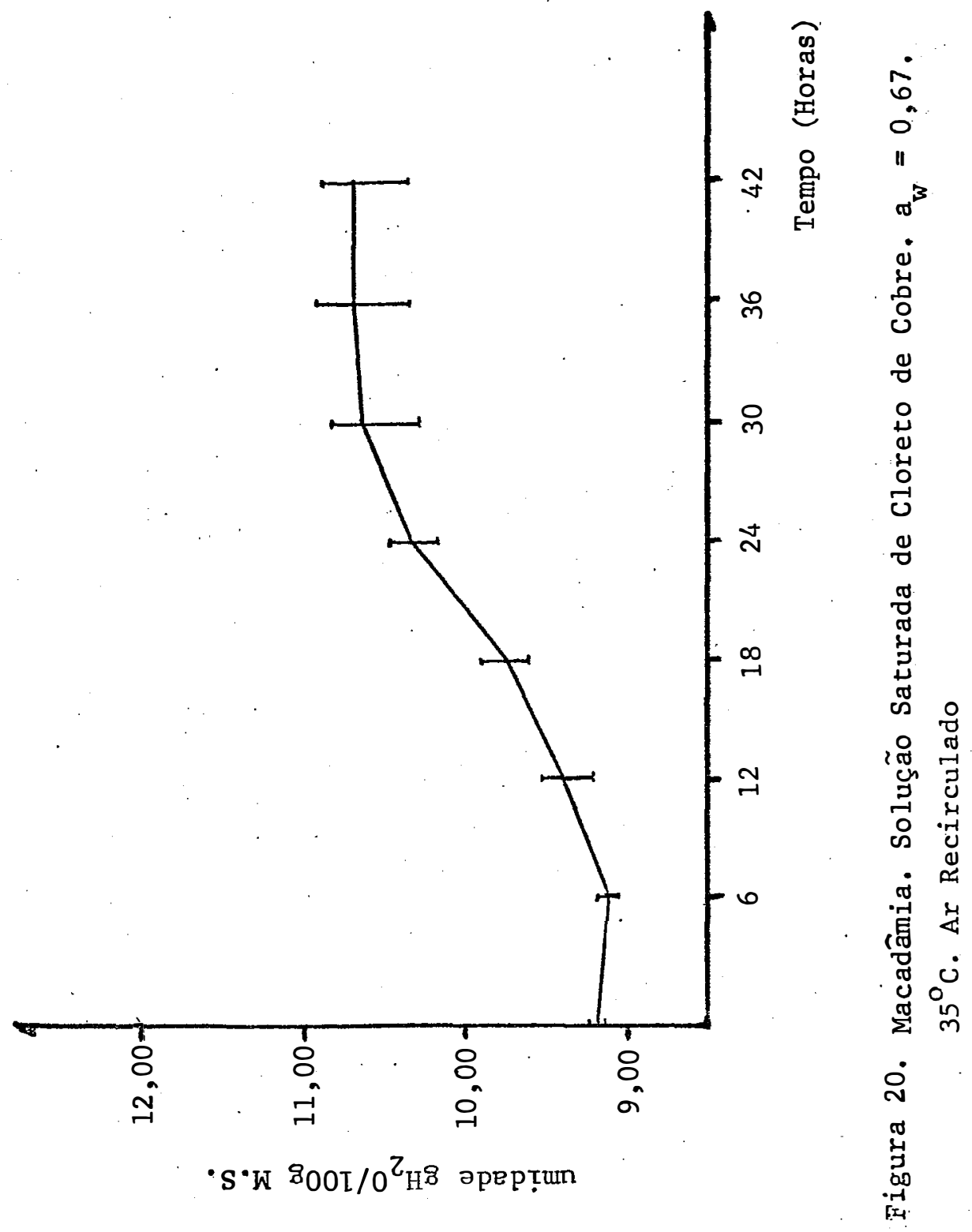




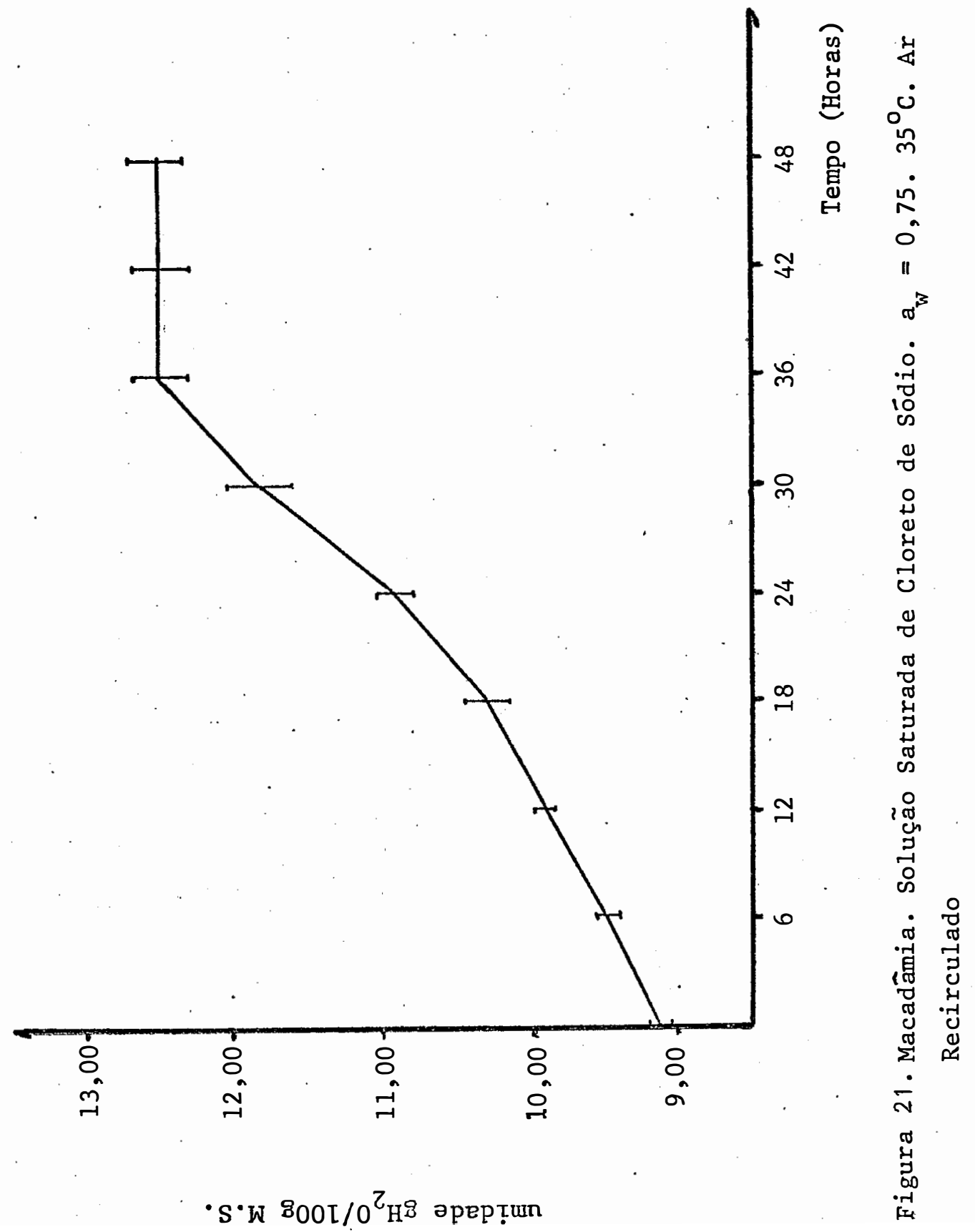




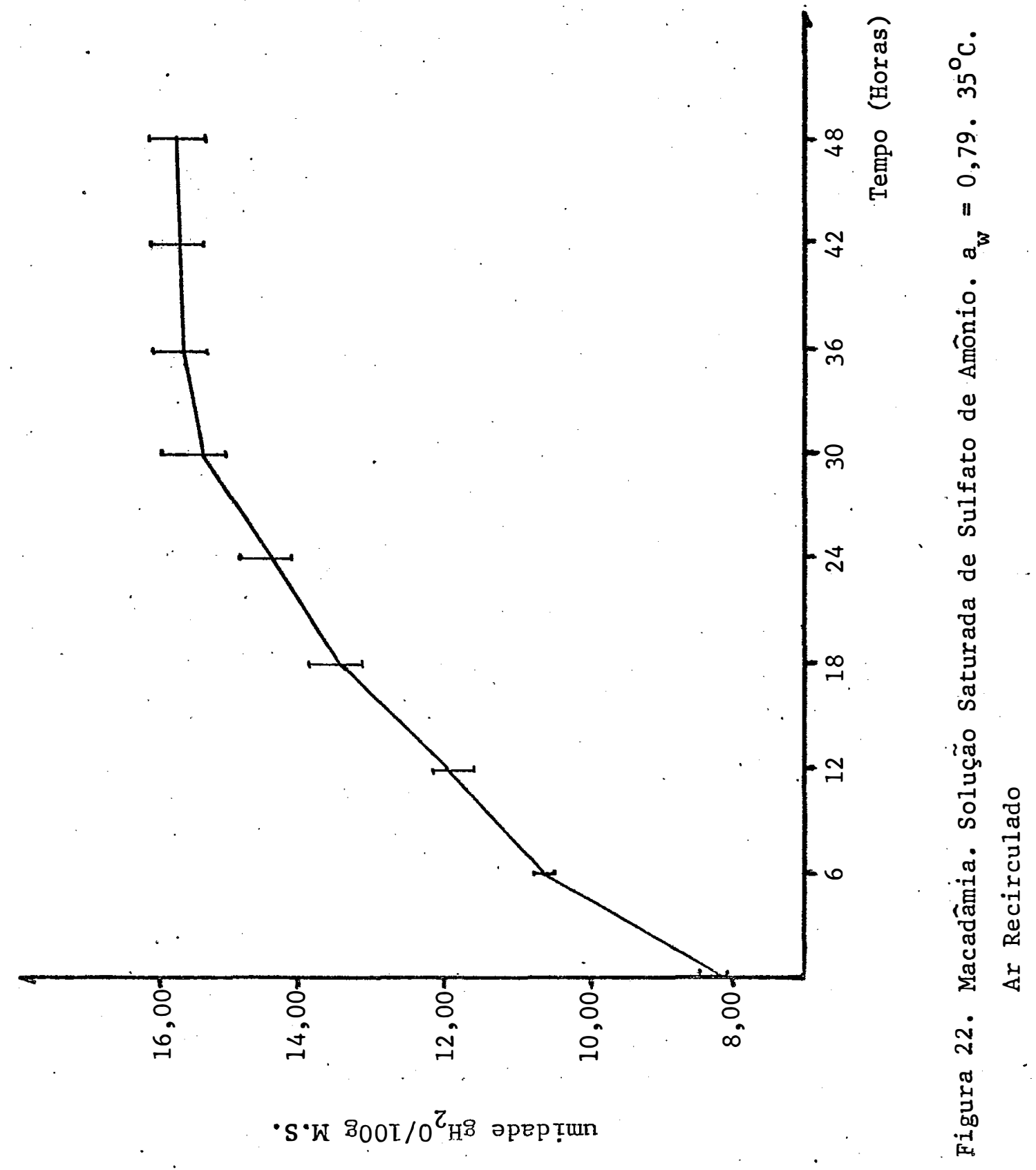




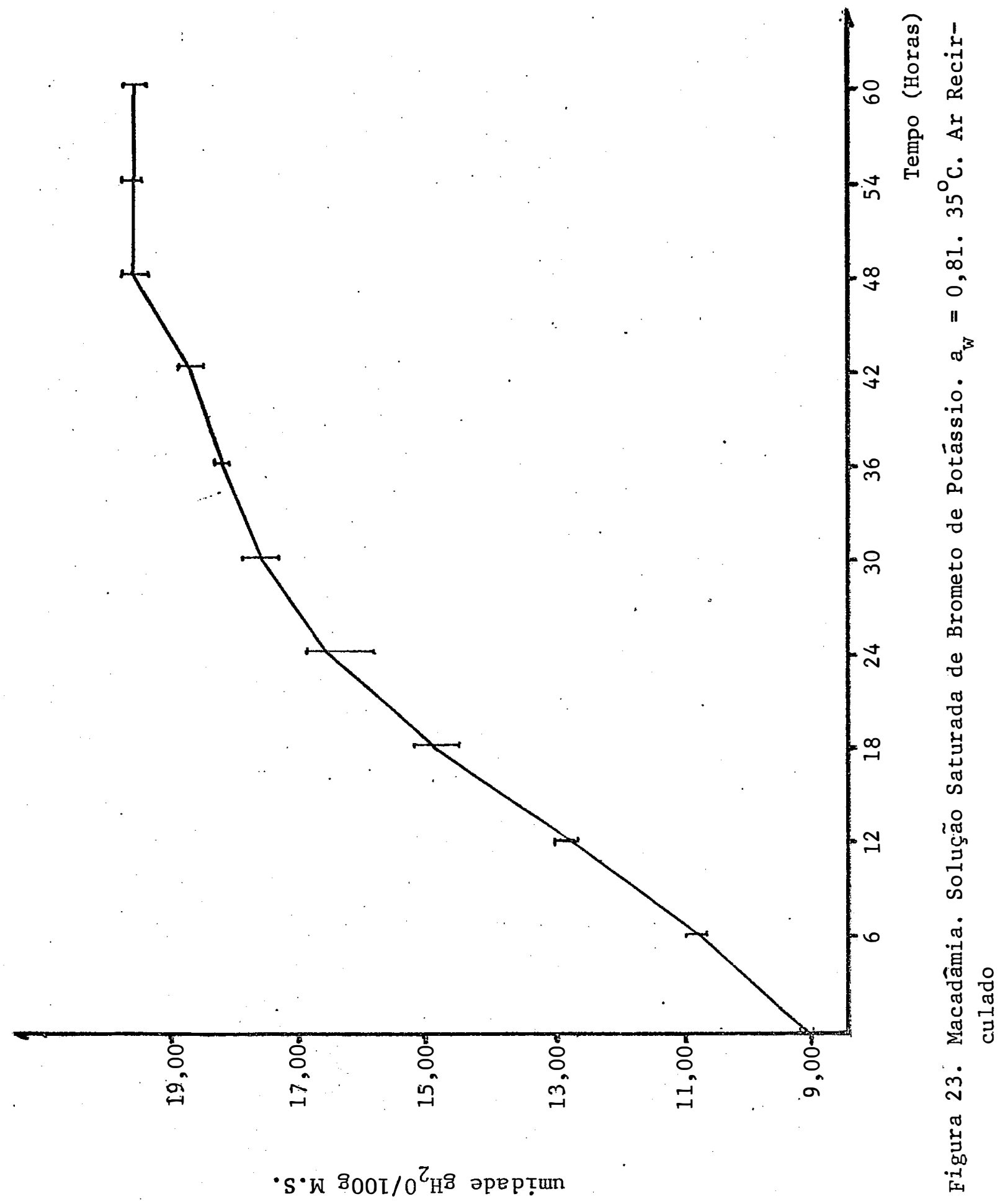




$$
\text { ل) }
$$




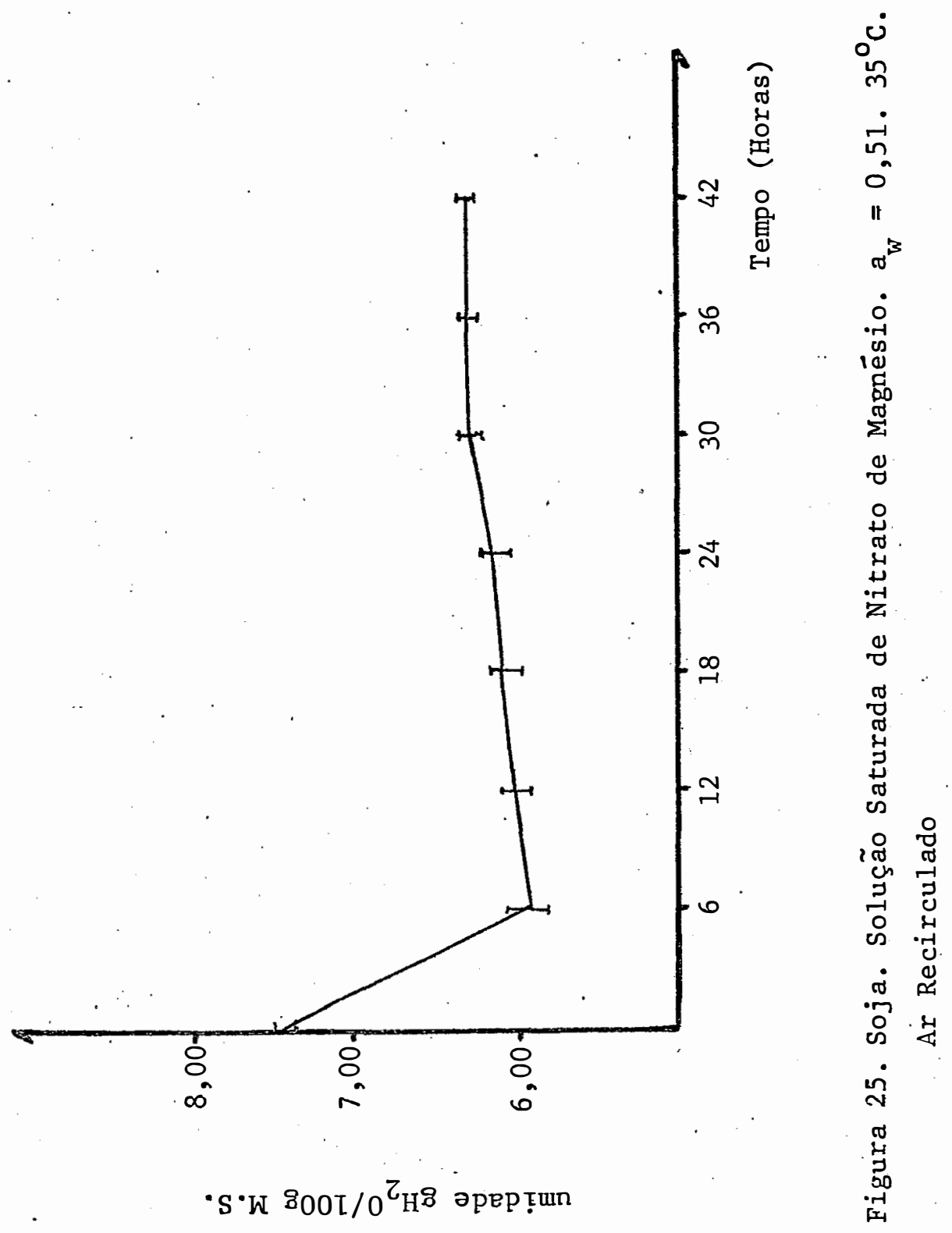




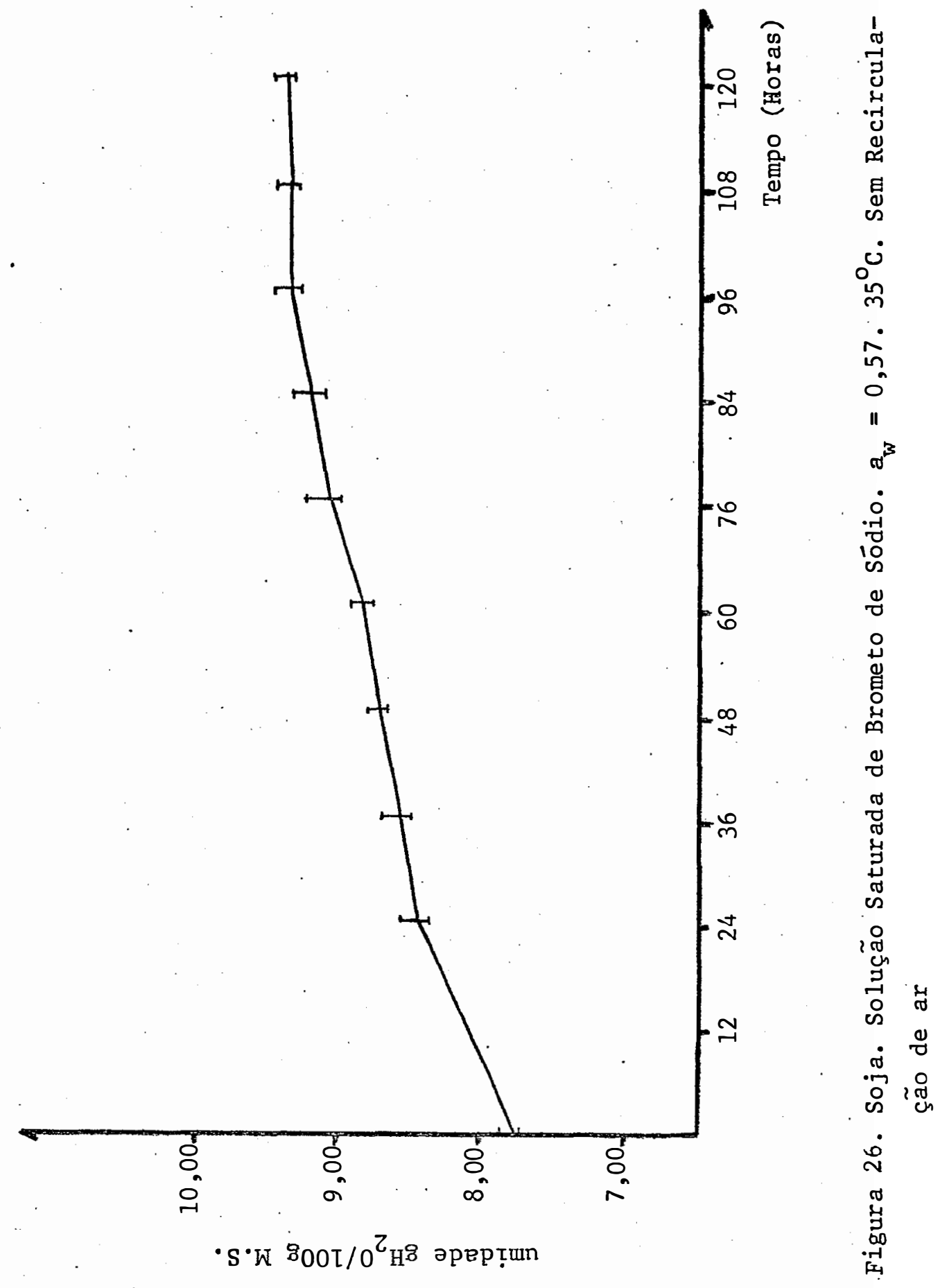




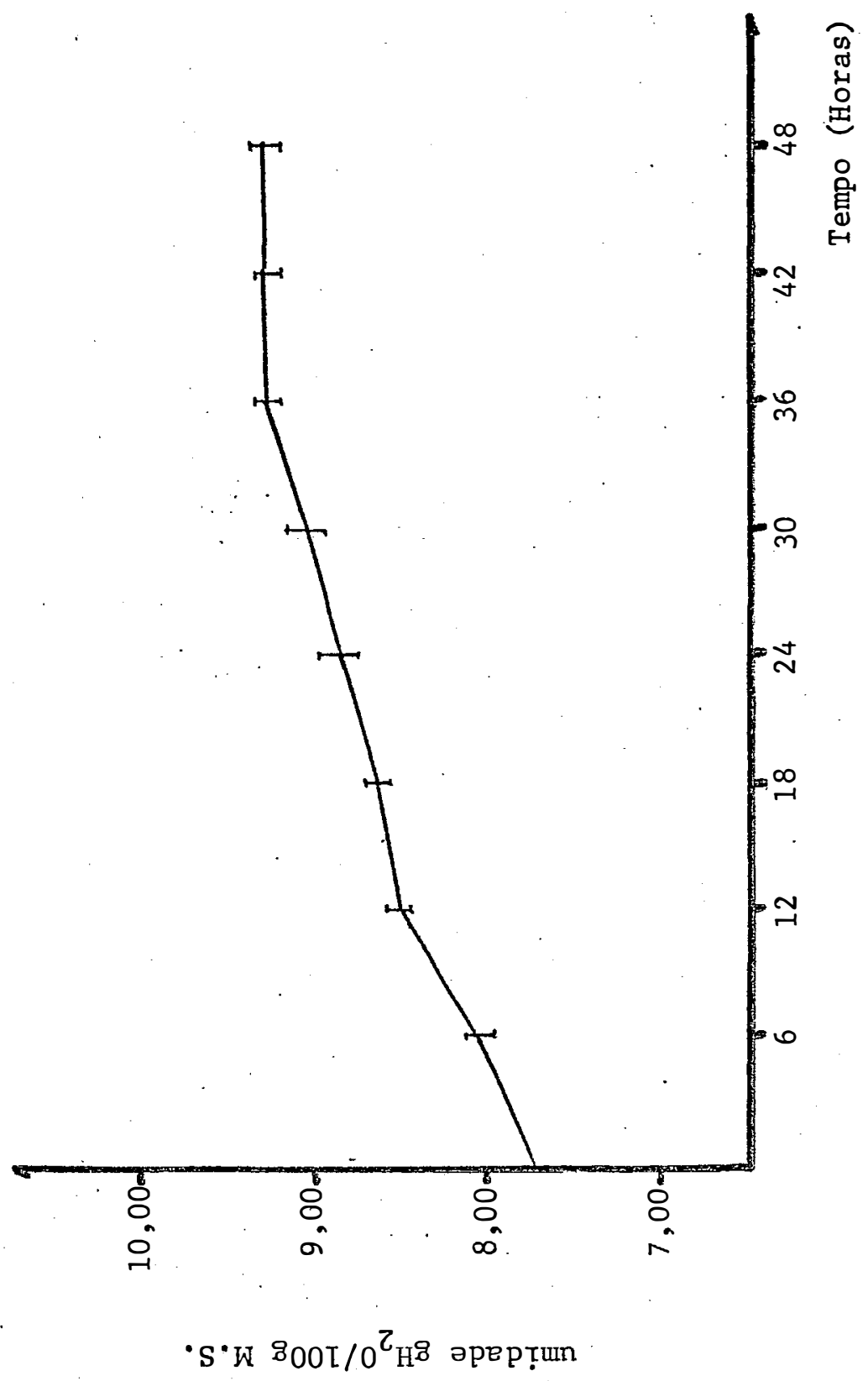

$\dot{4}$

jo

n

in

II

(1)

0

id

ซึ

옹

॥

คํำ

ฮั

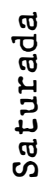

10

यै

क गे

宓

ล்

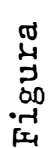




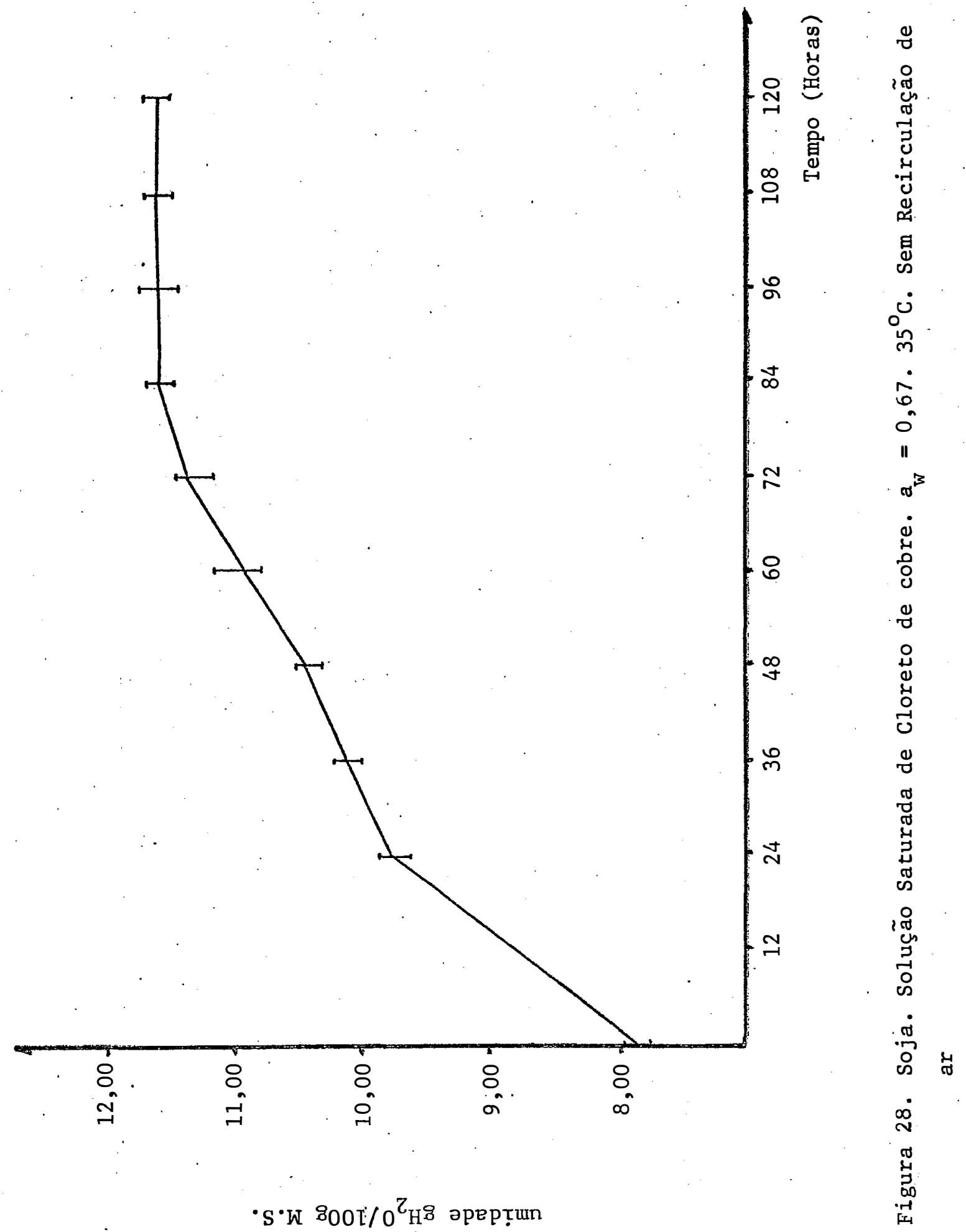




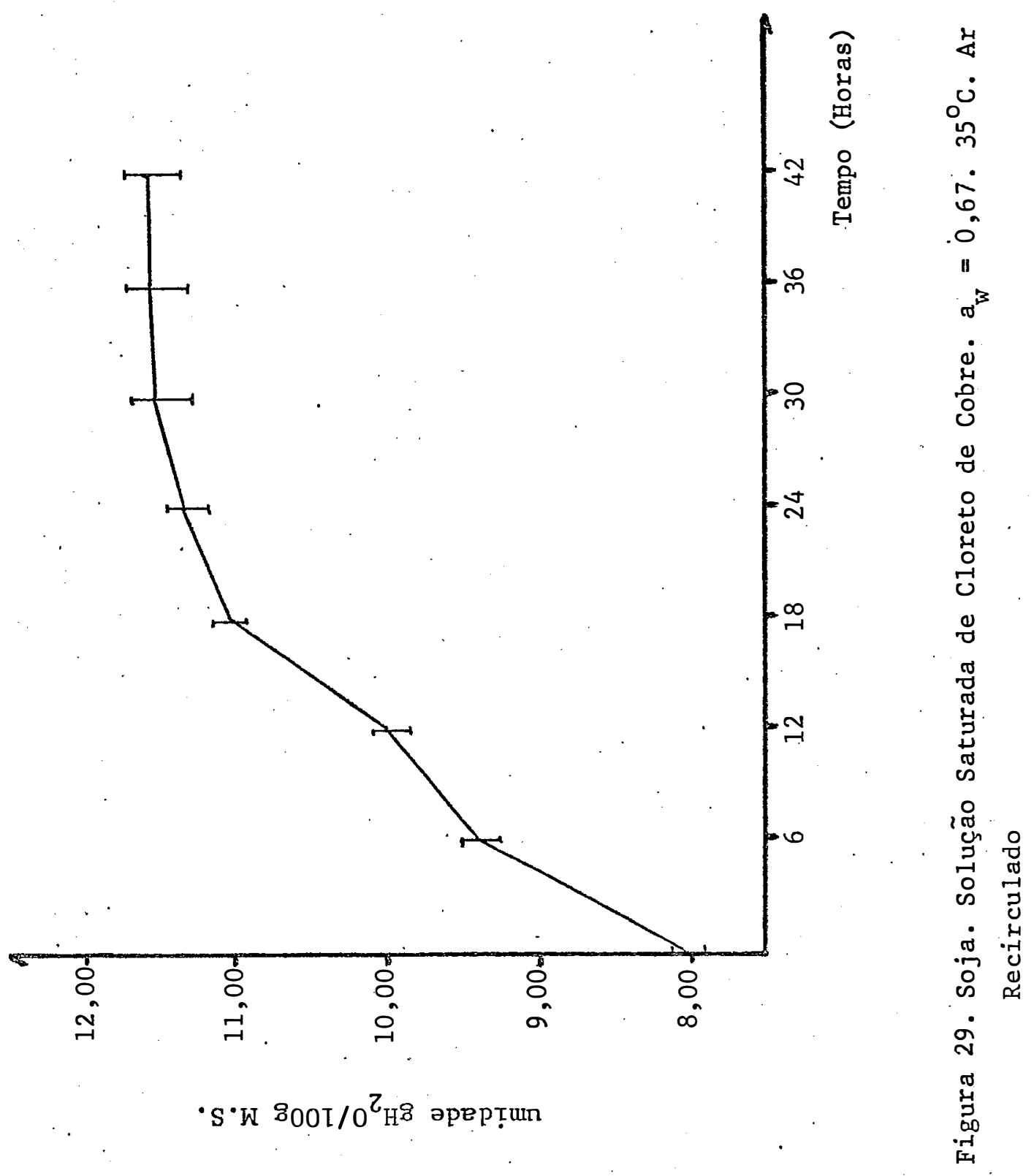




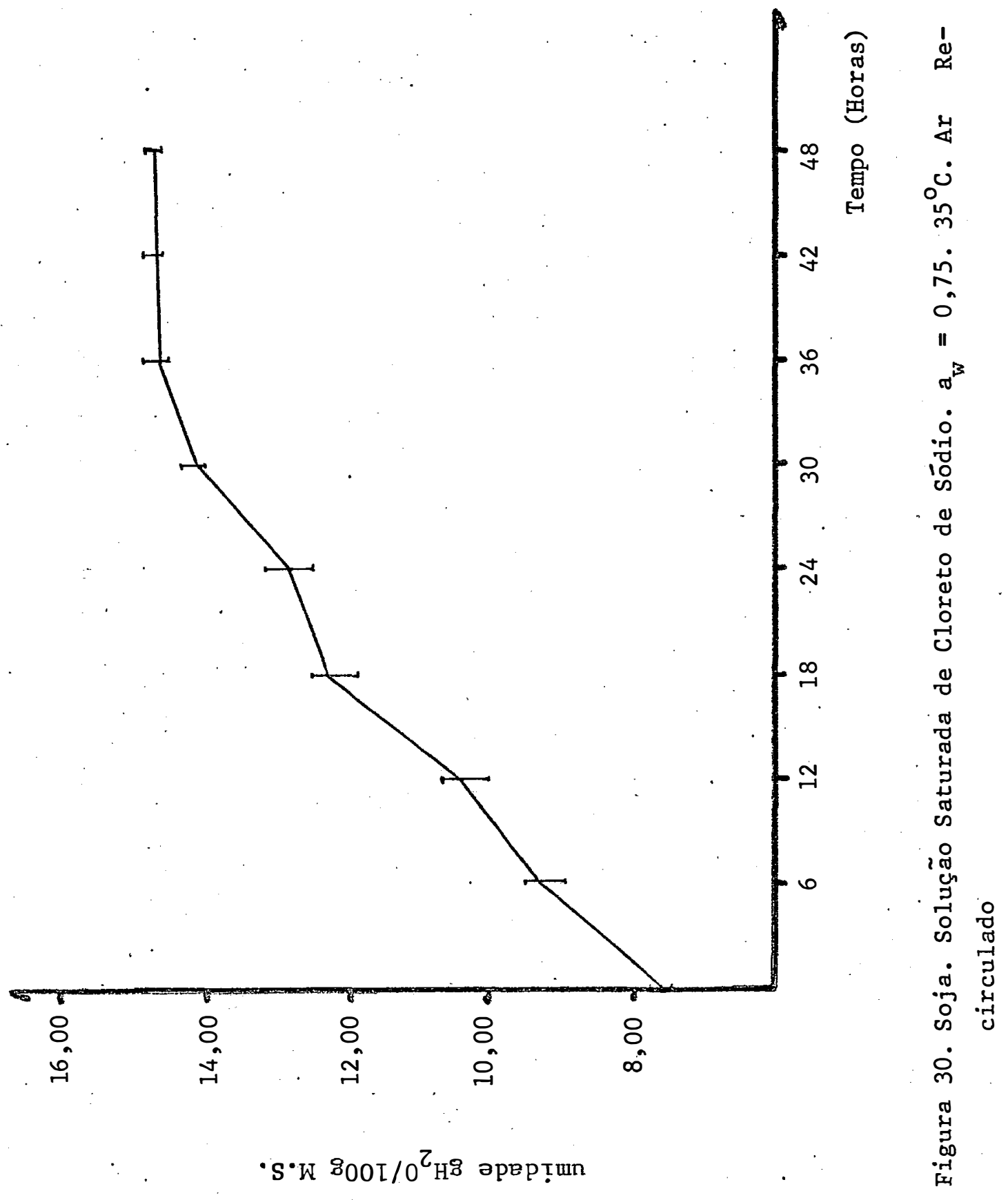




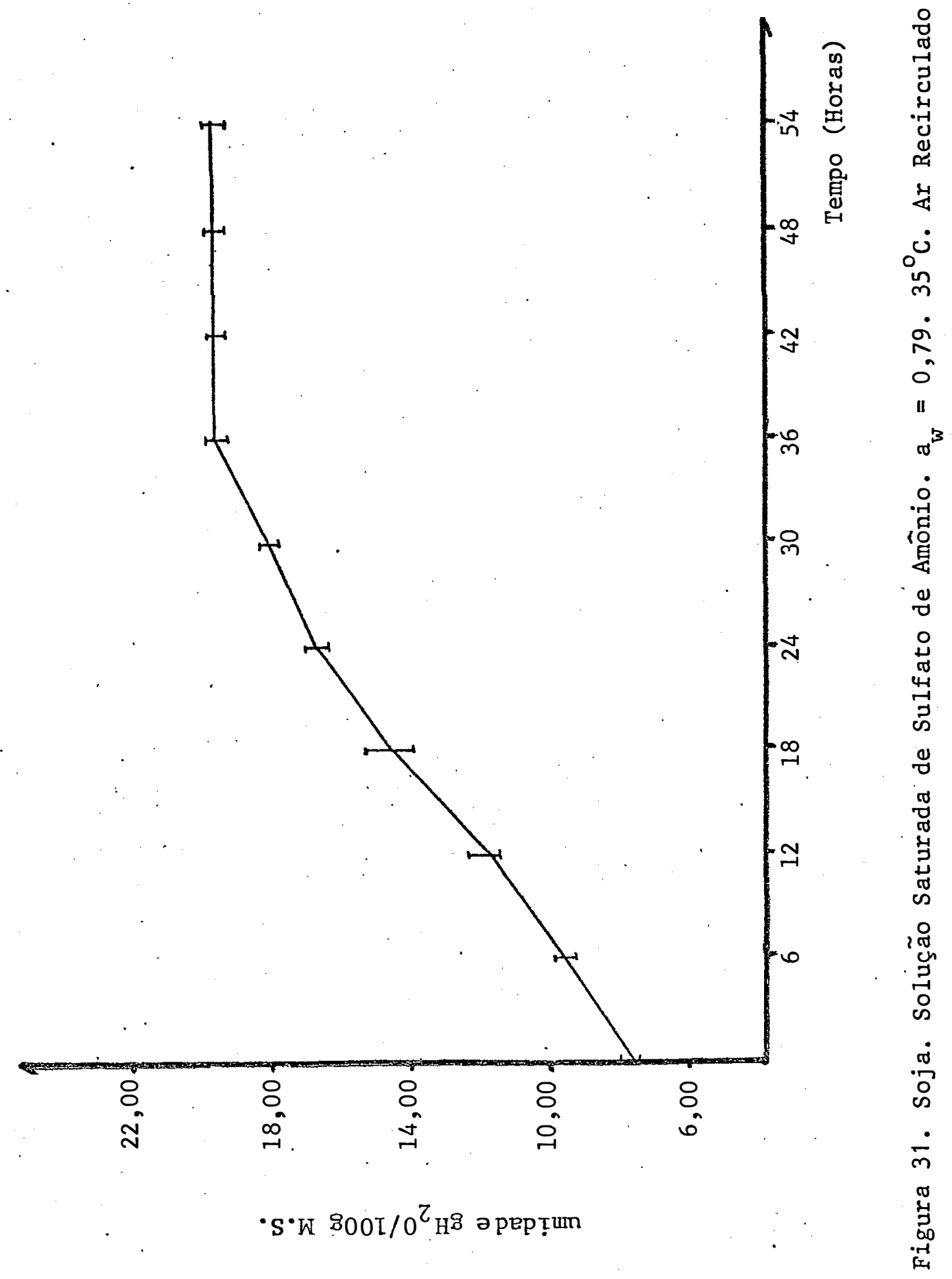




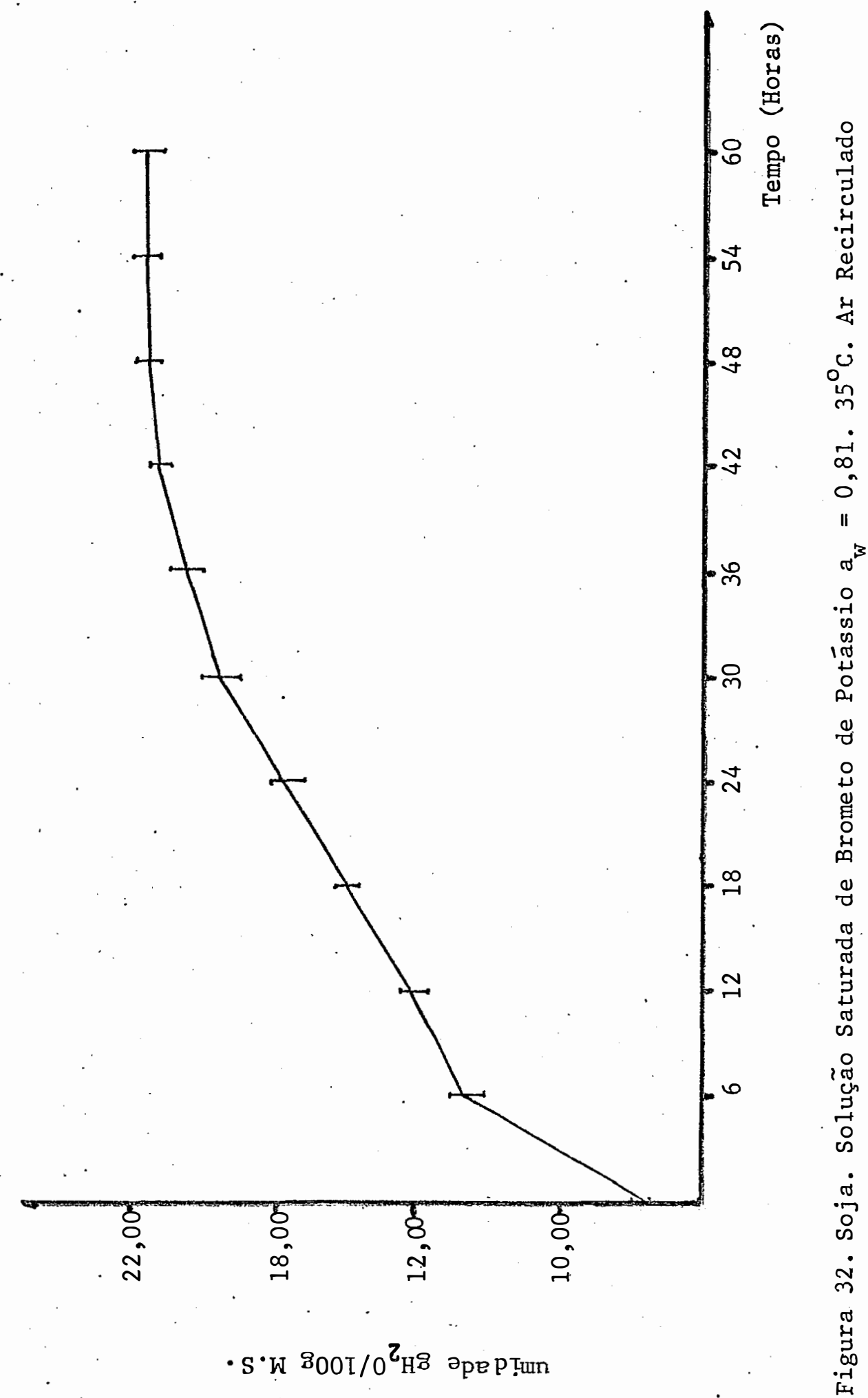




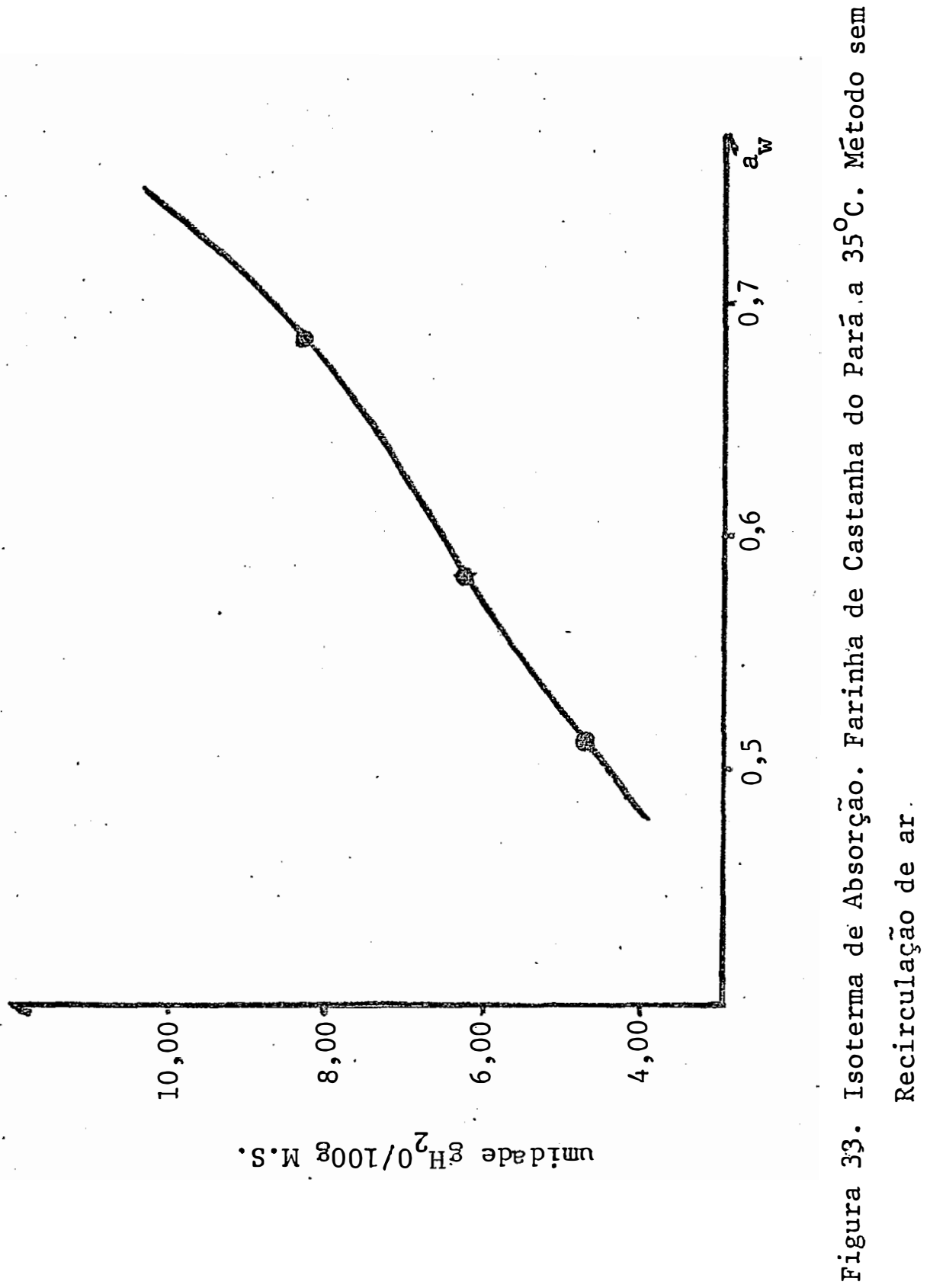




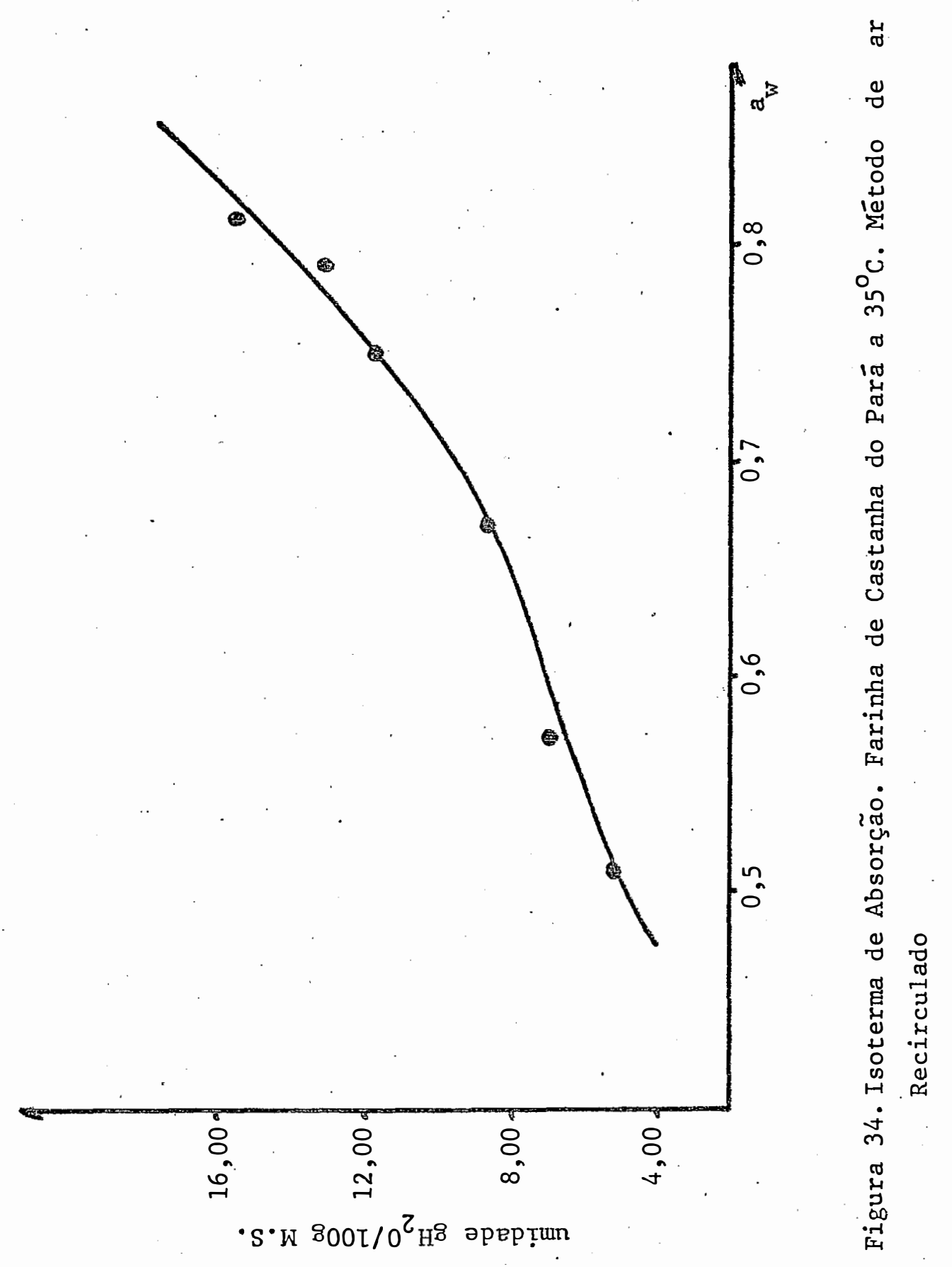




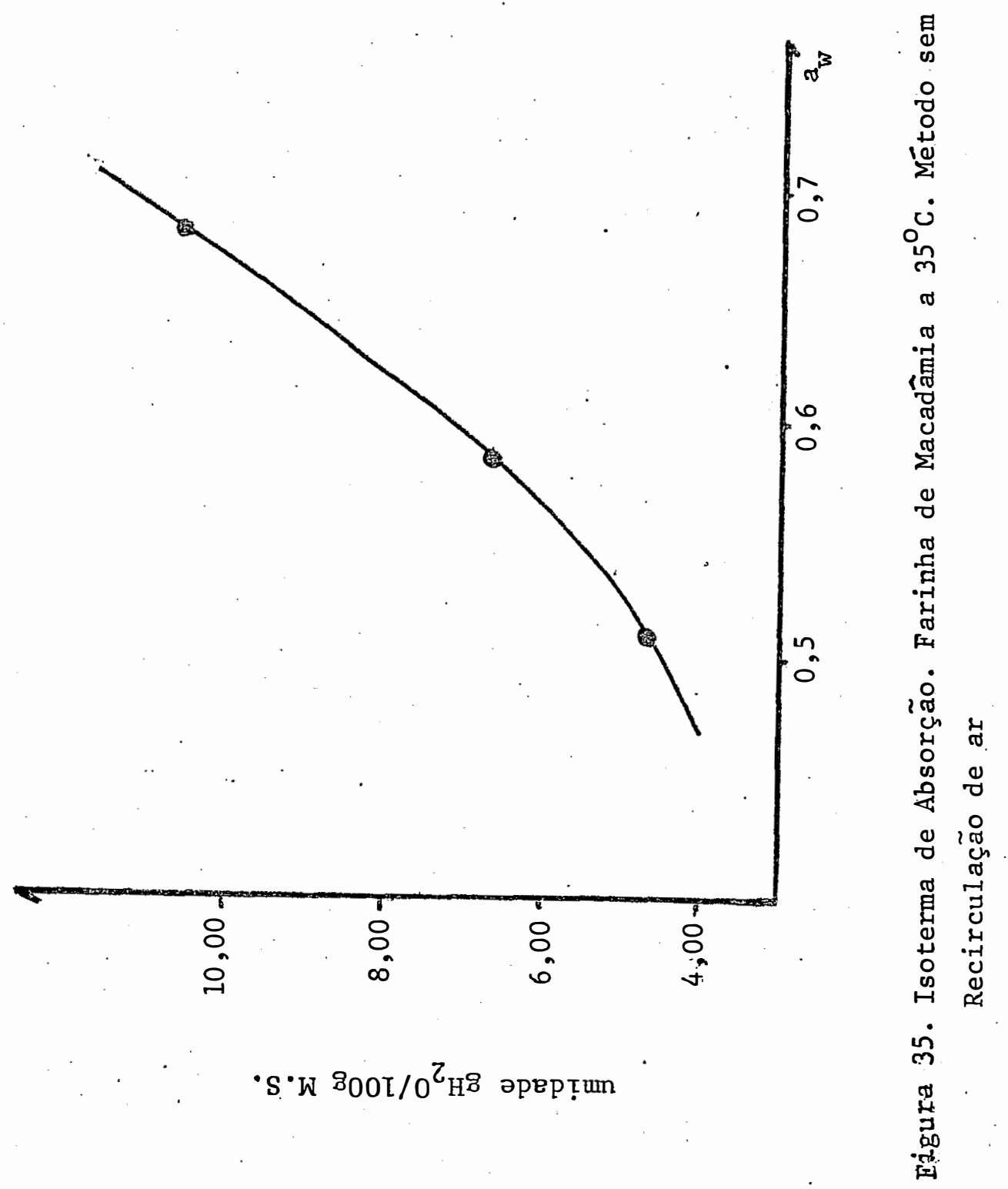




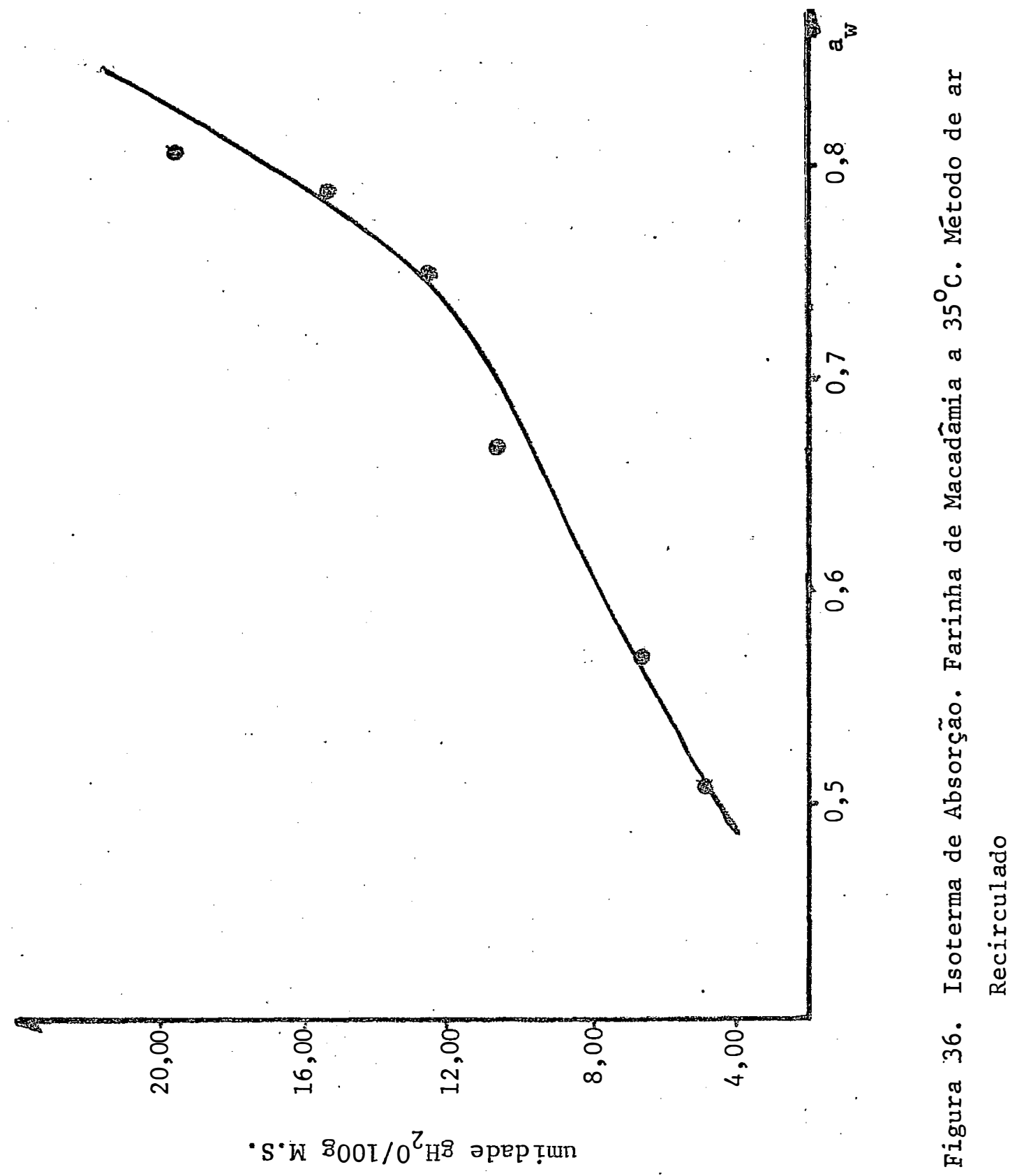




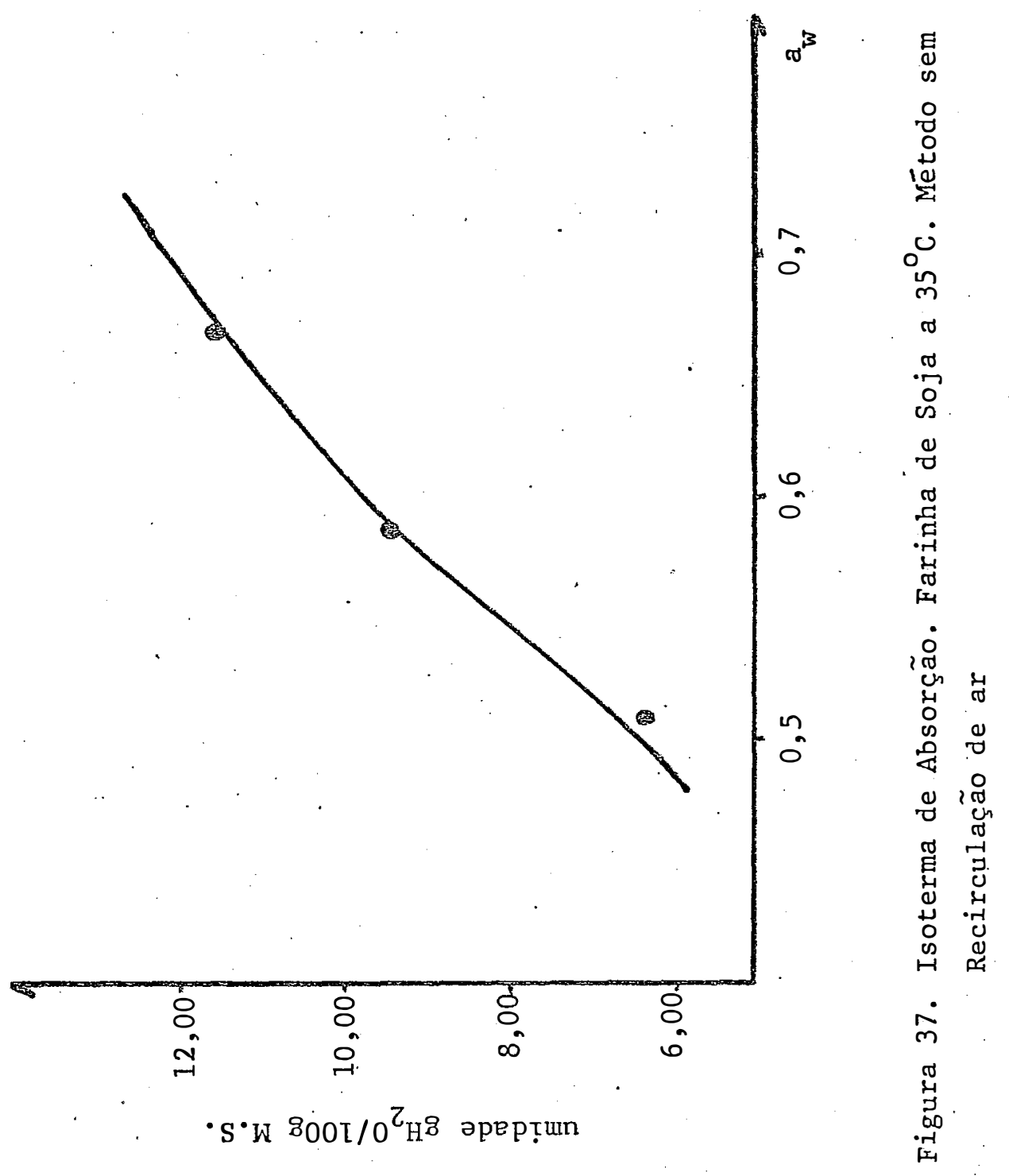




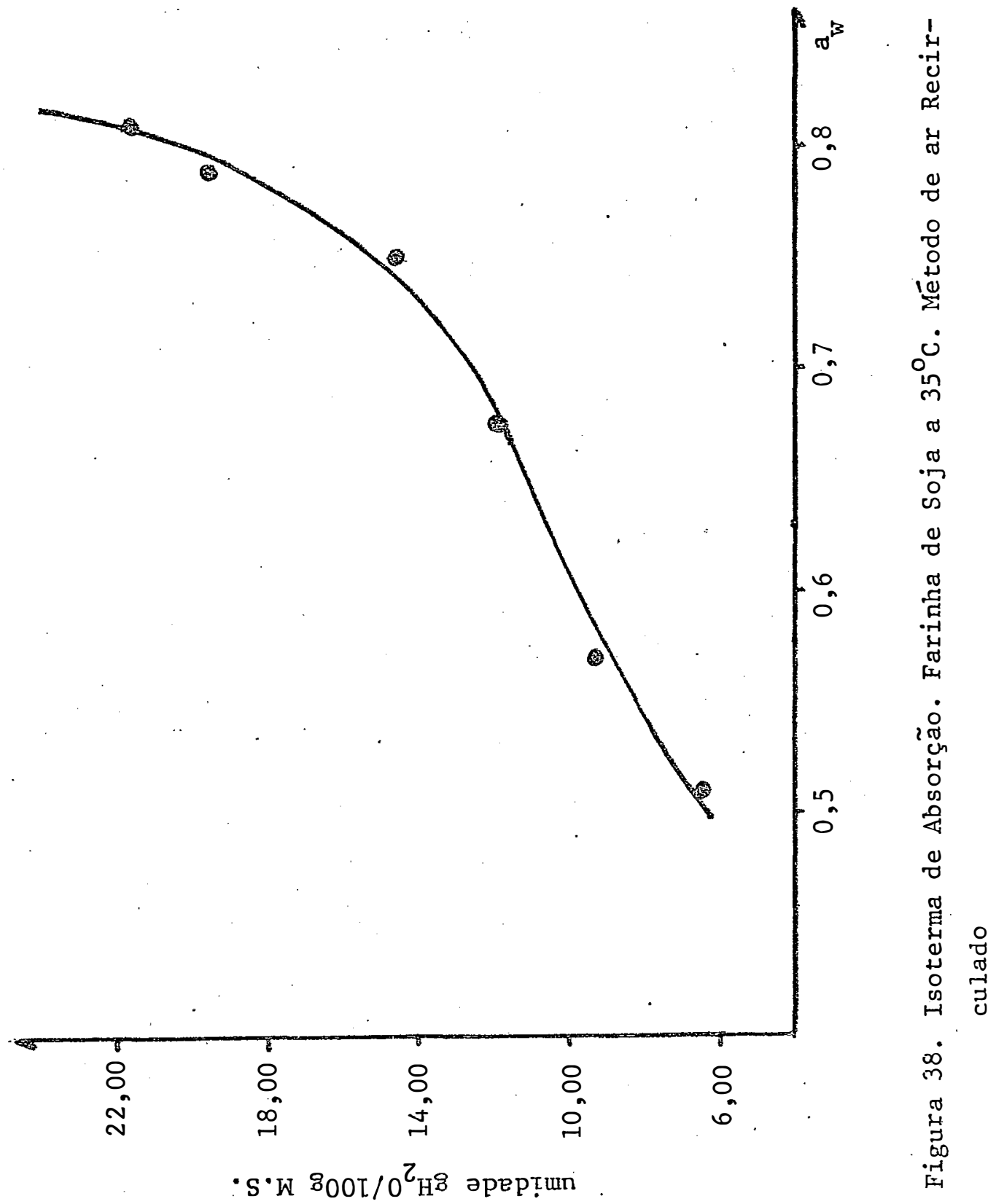




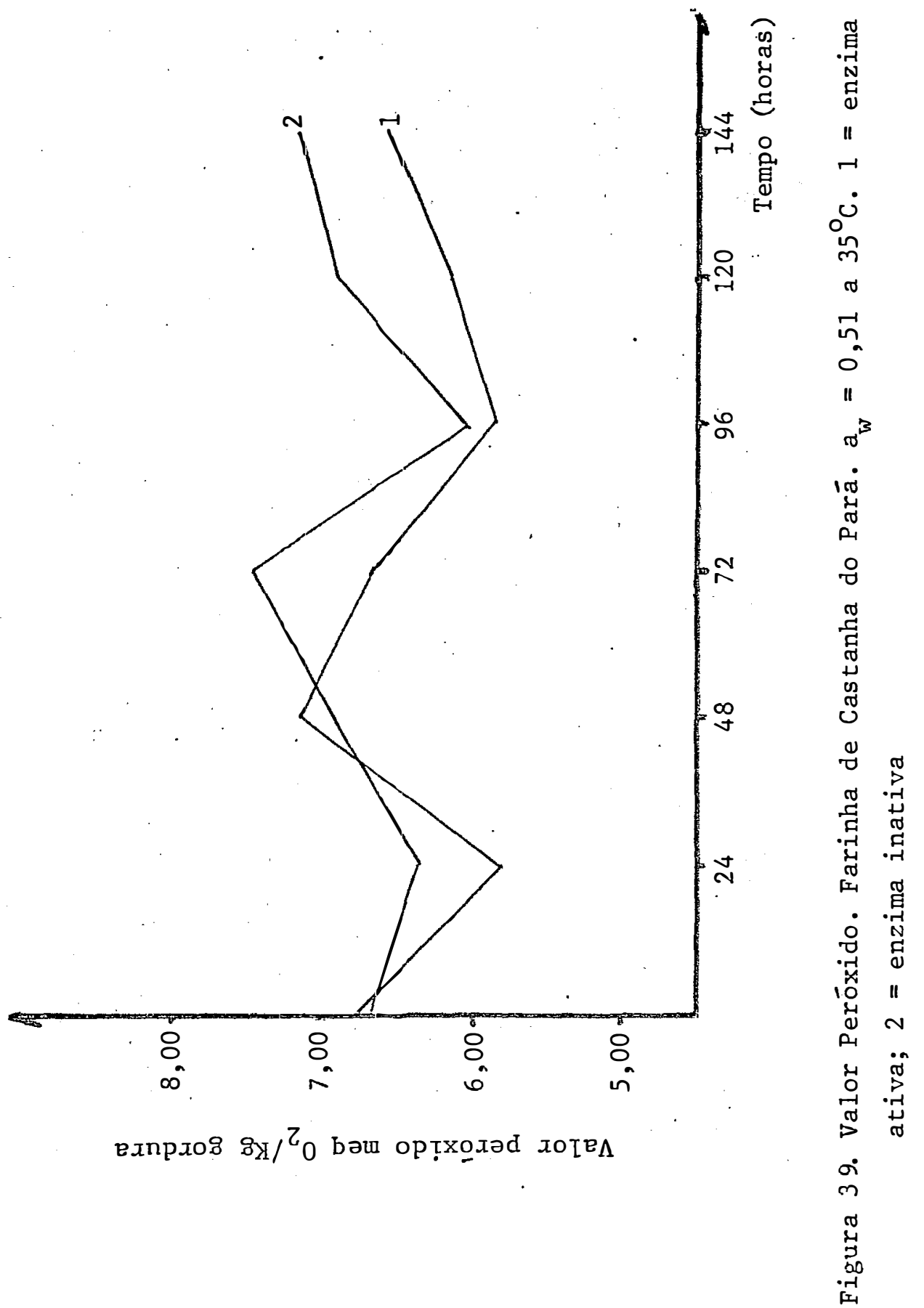




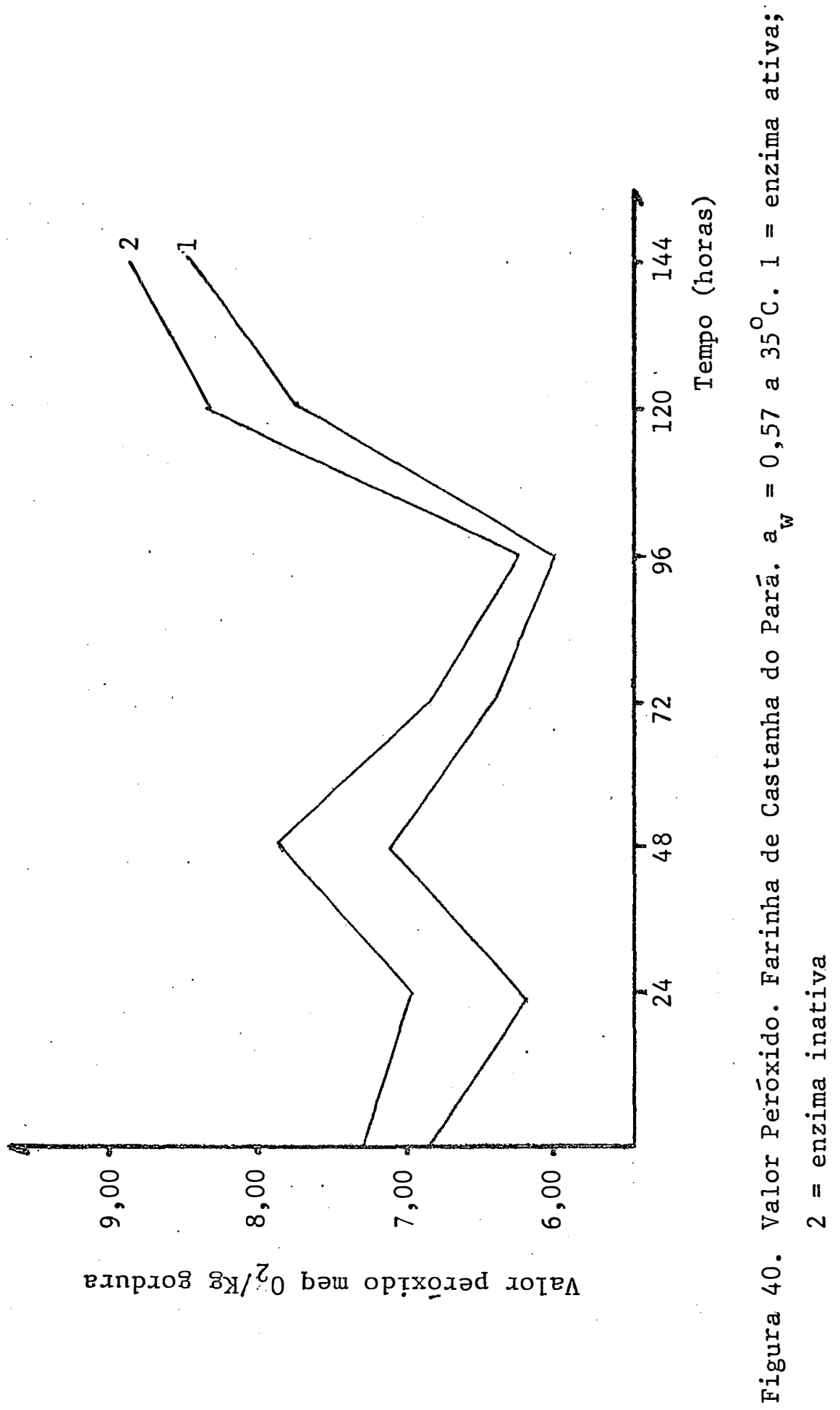




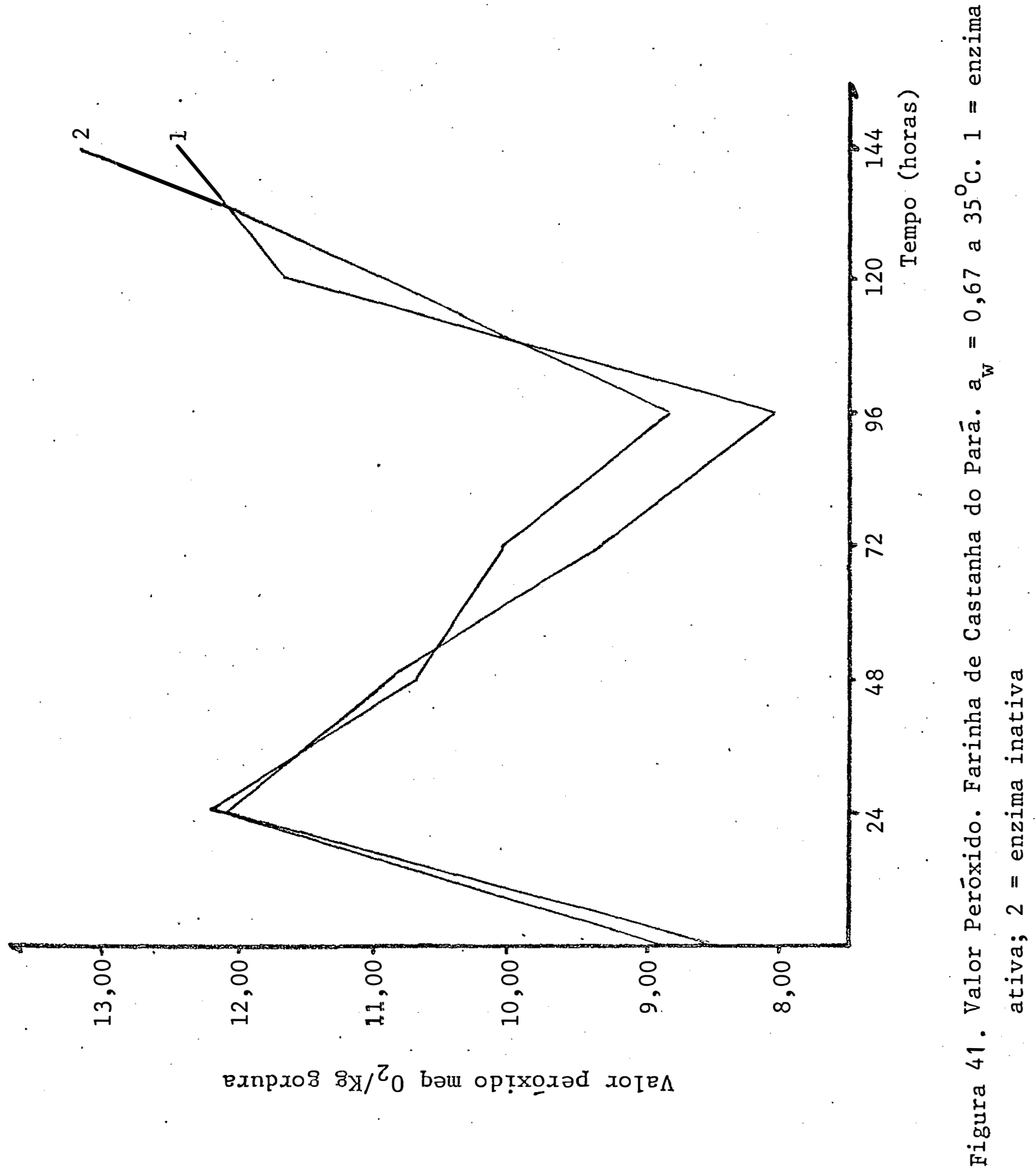




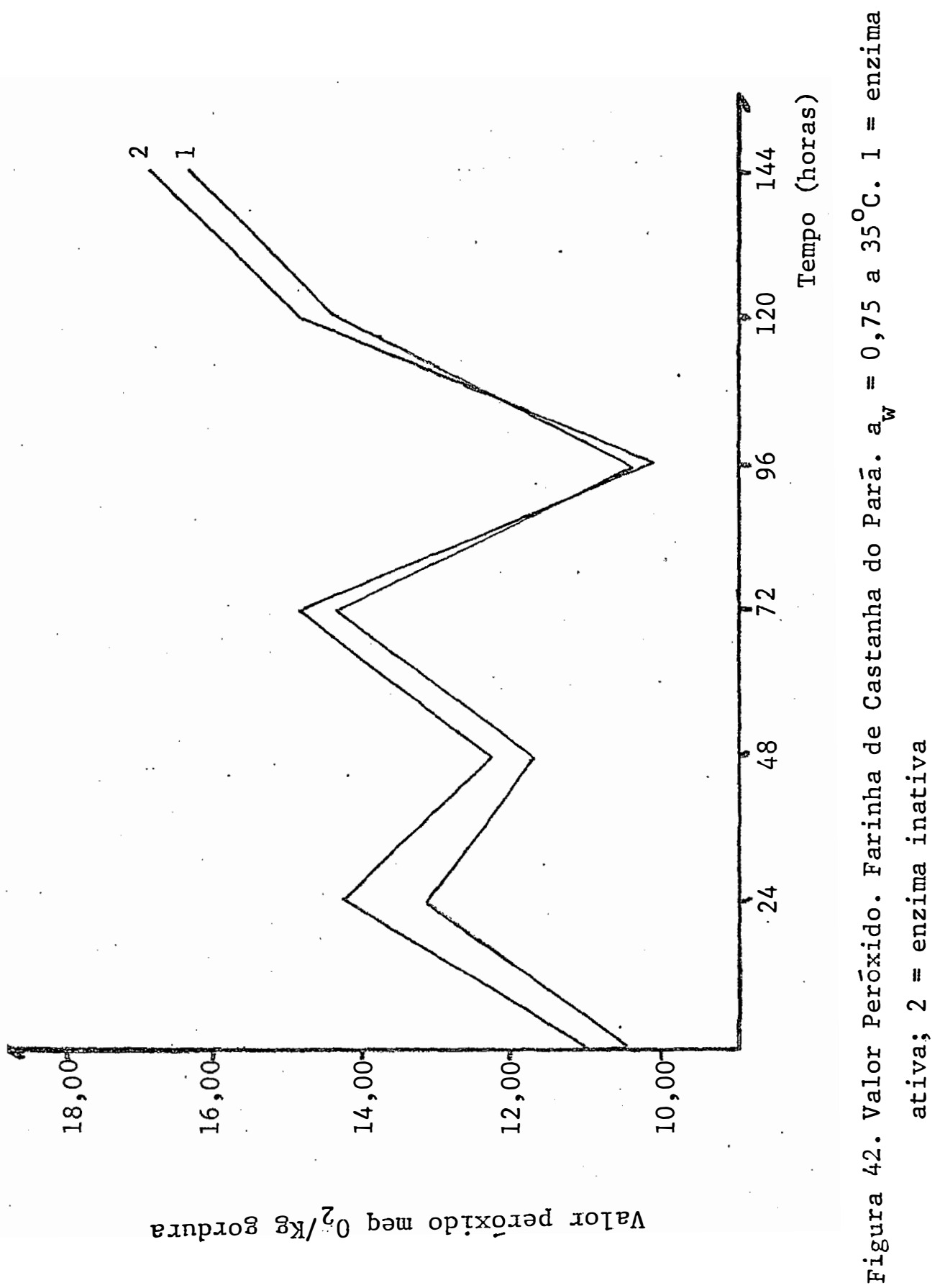




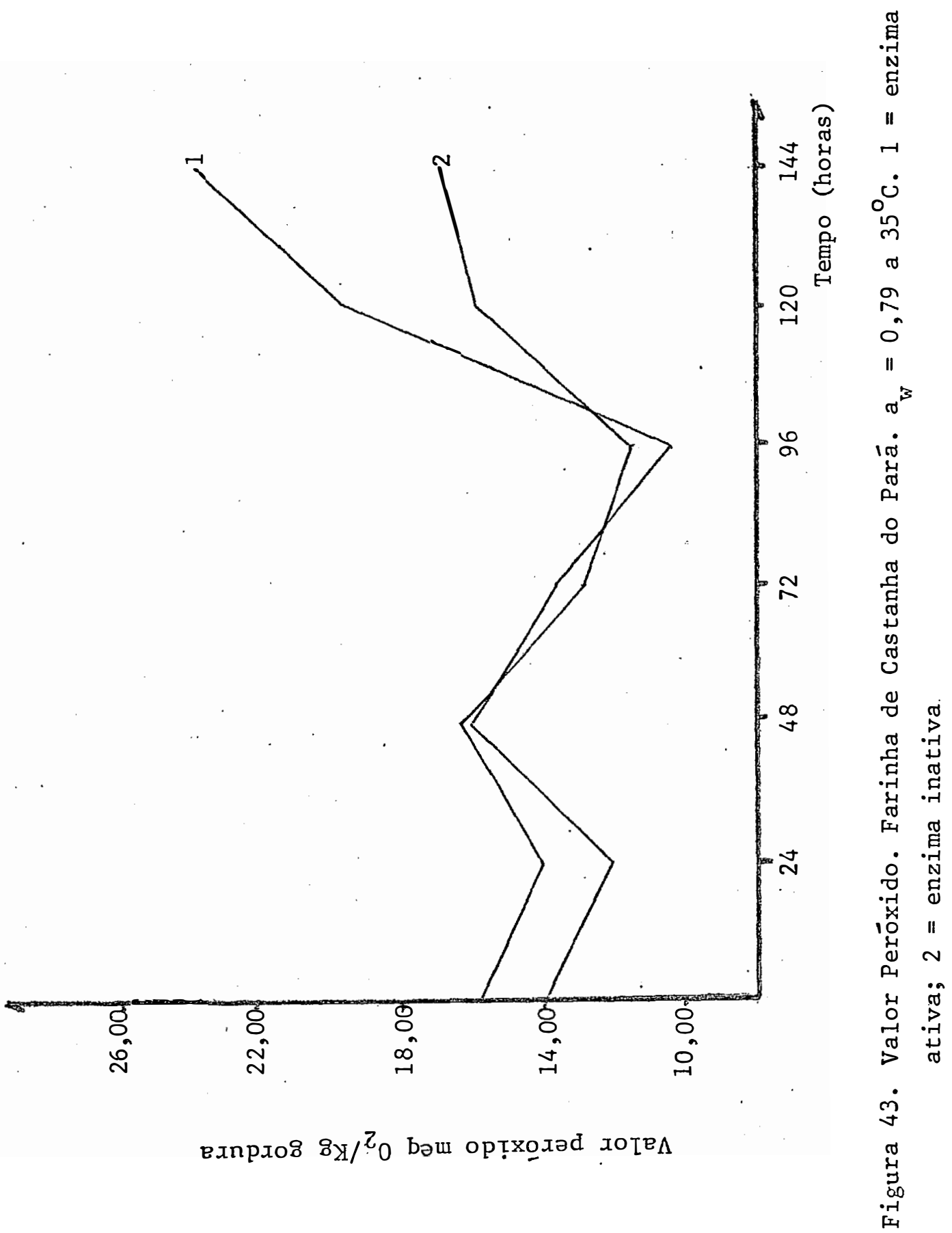




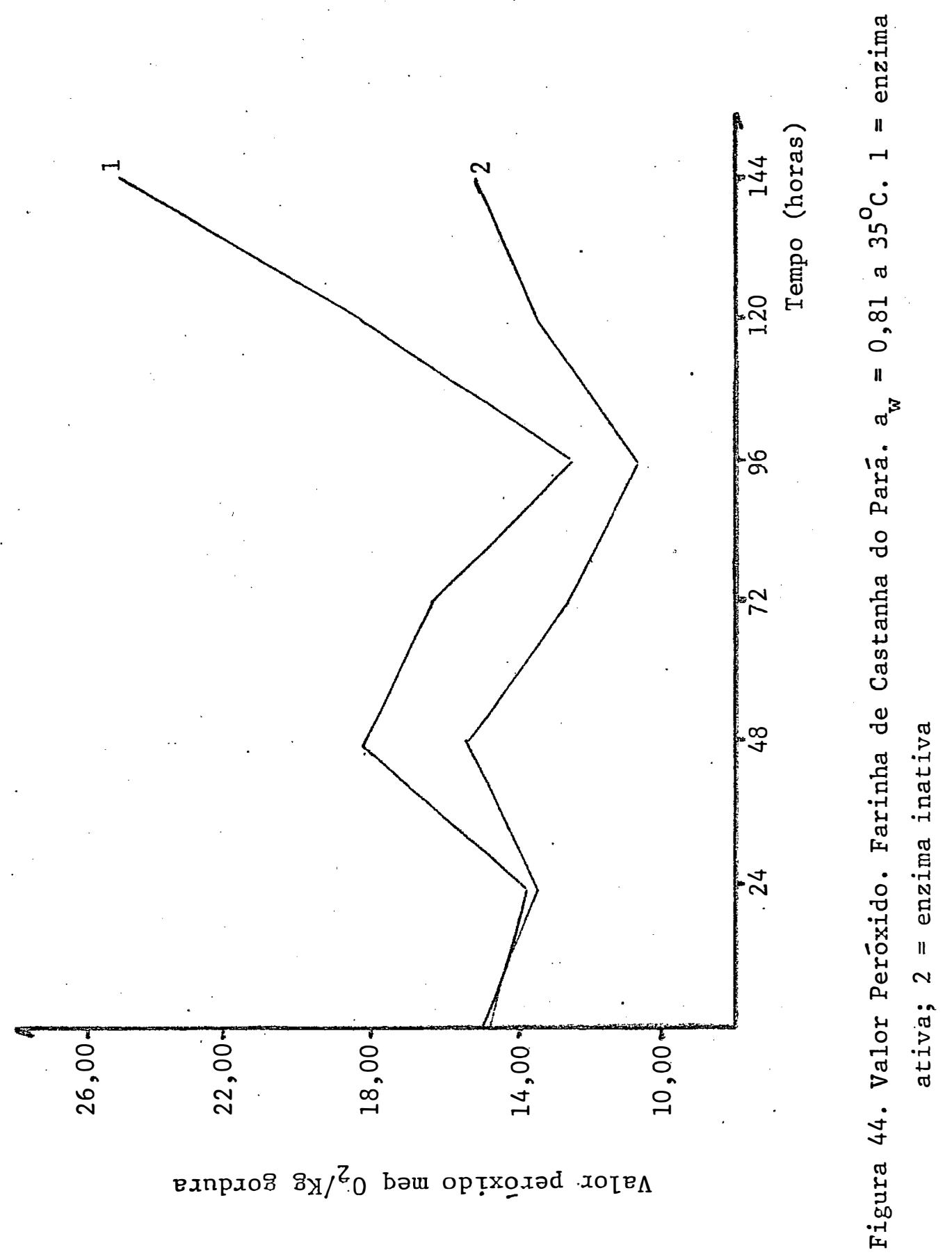




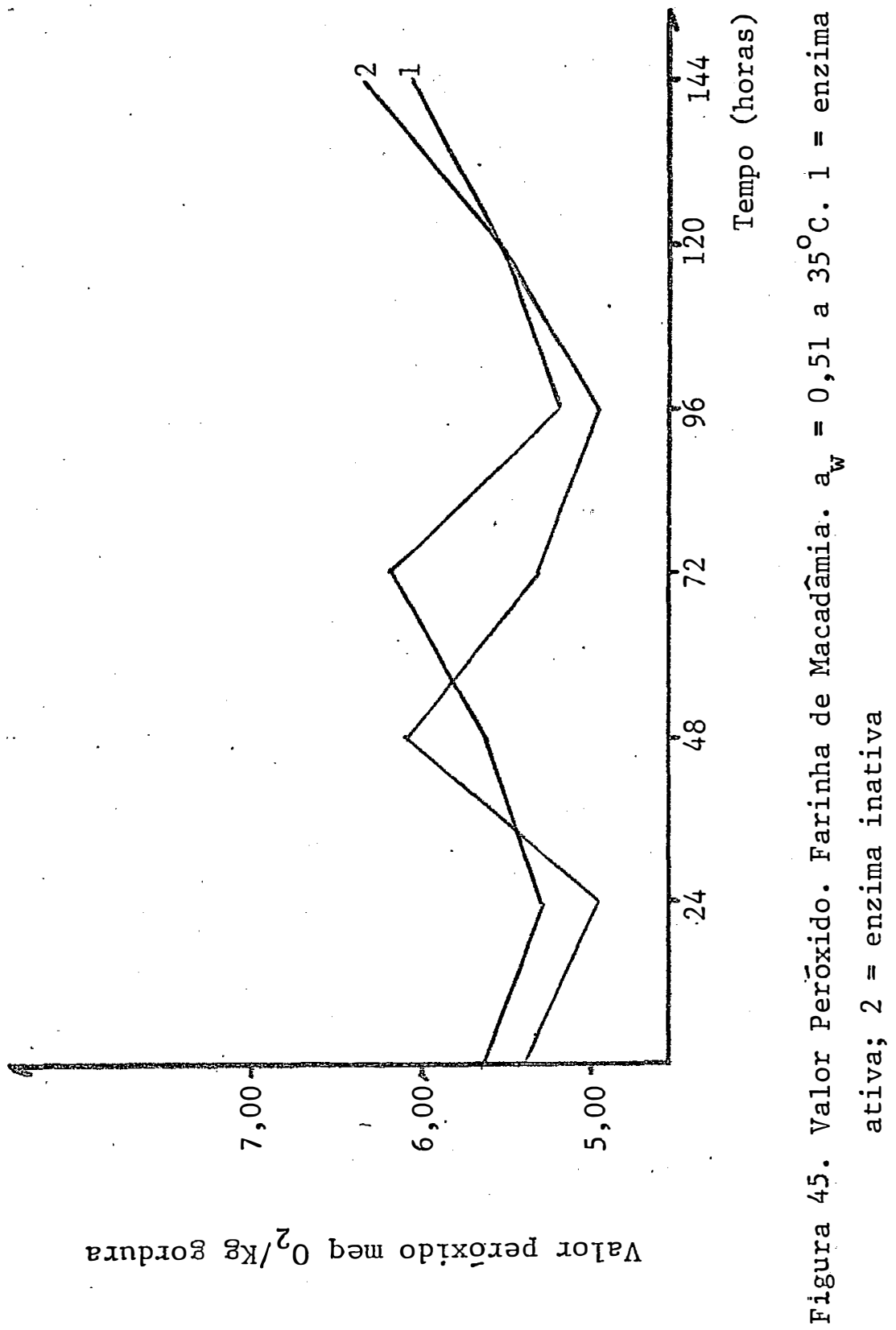




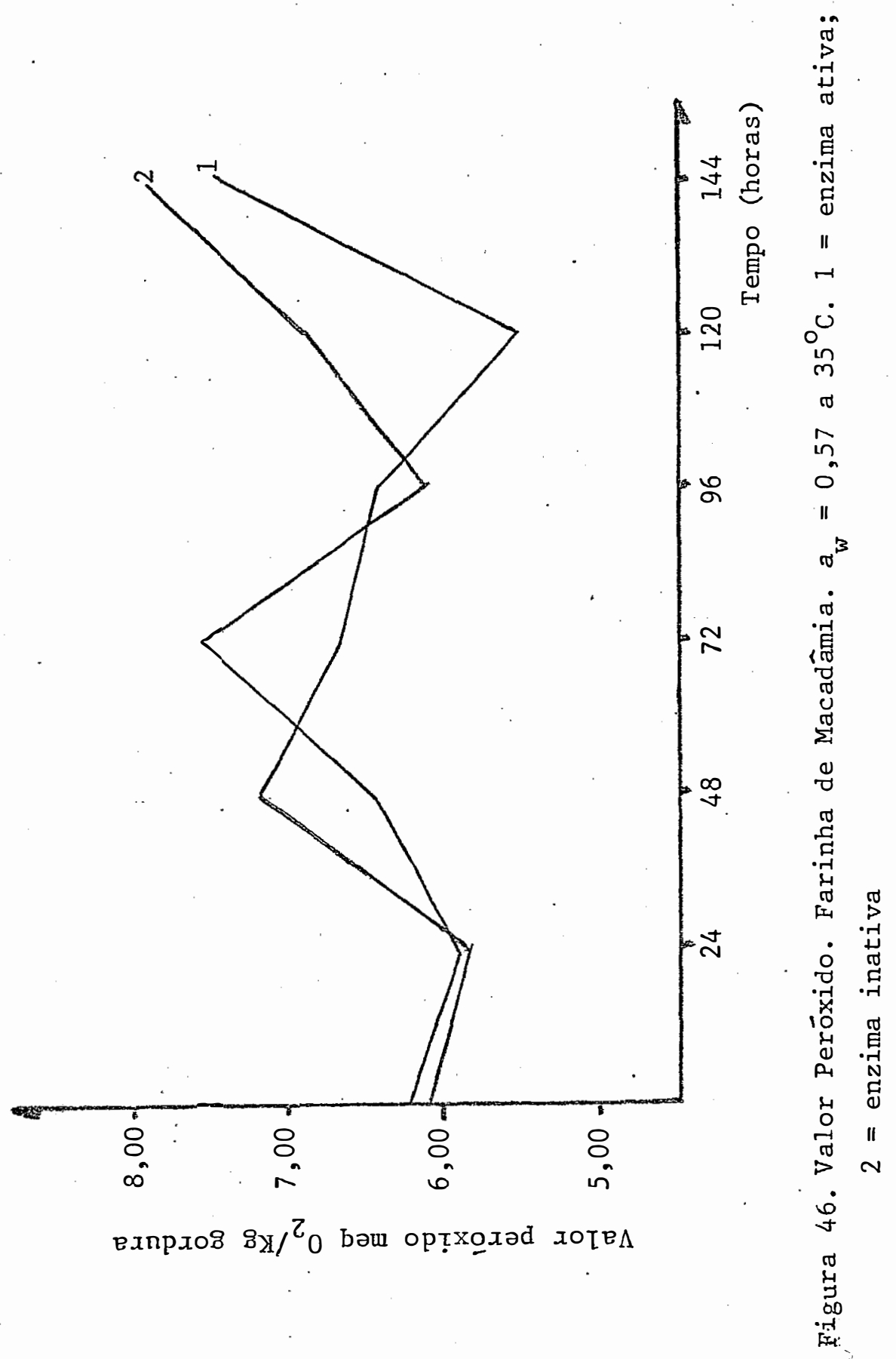




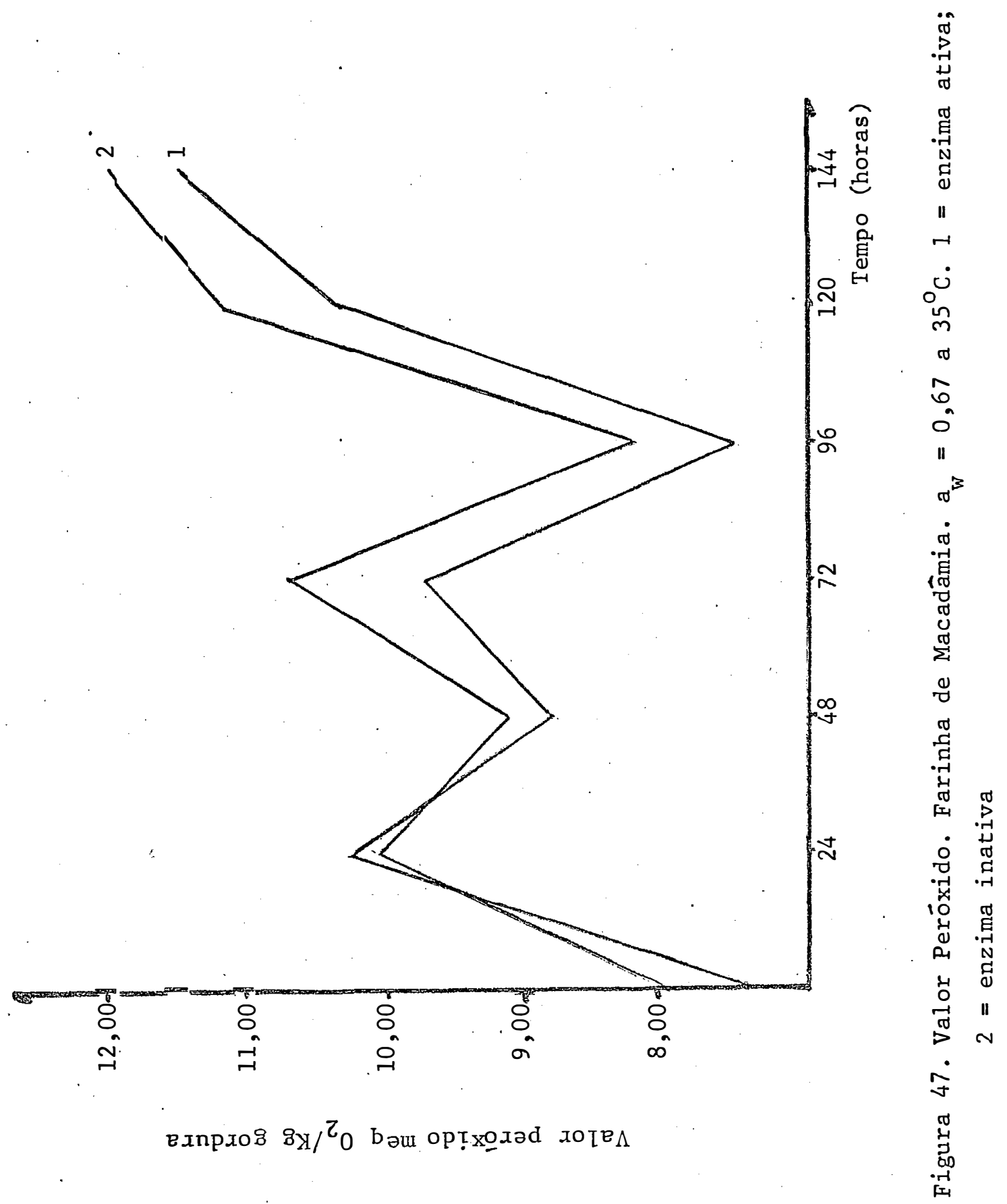




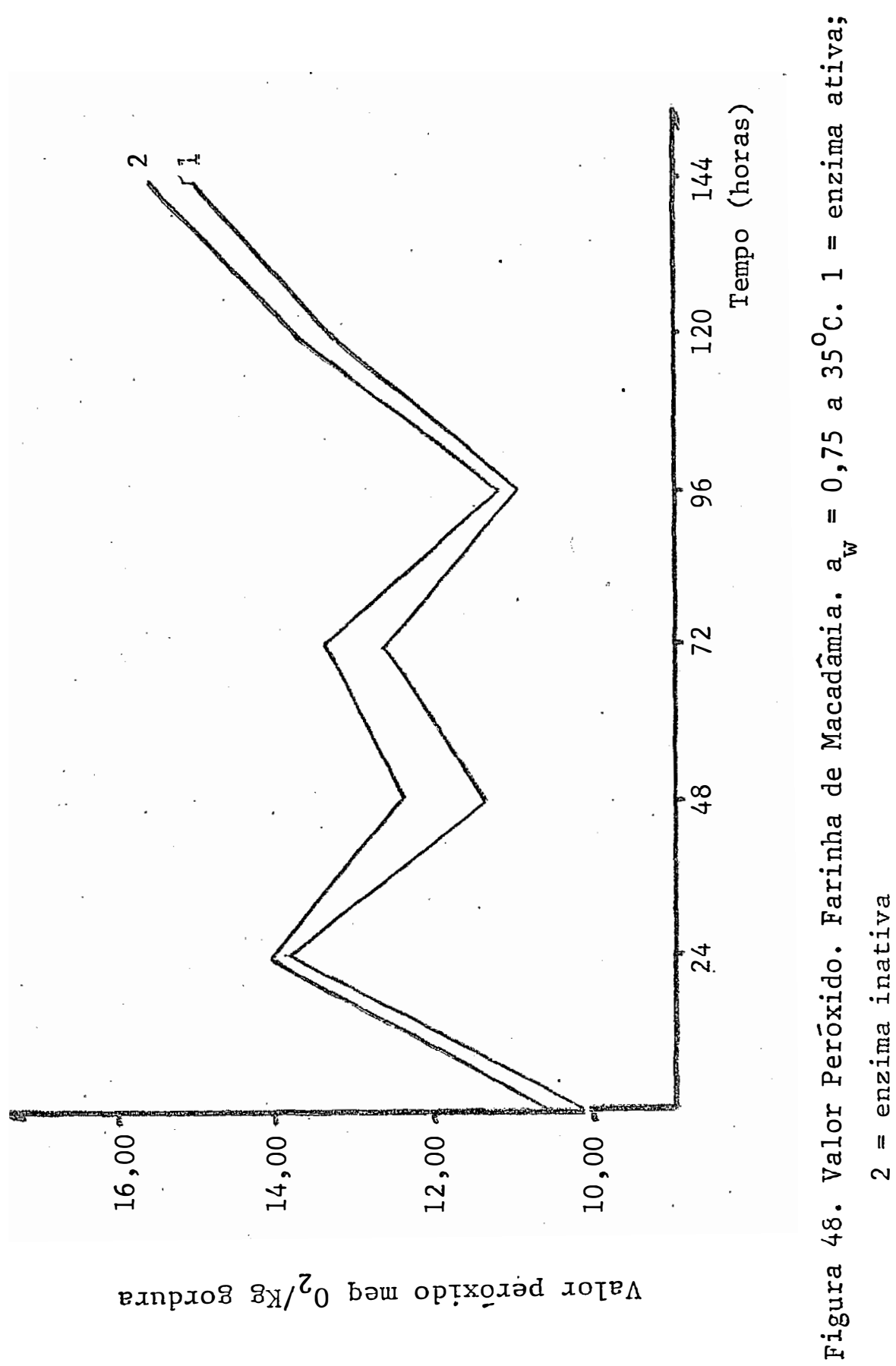




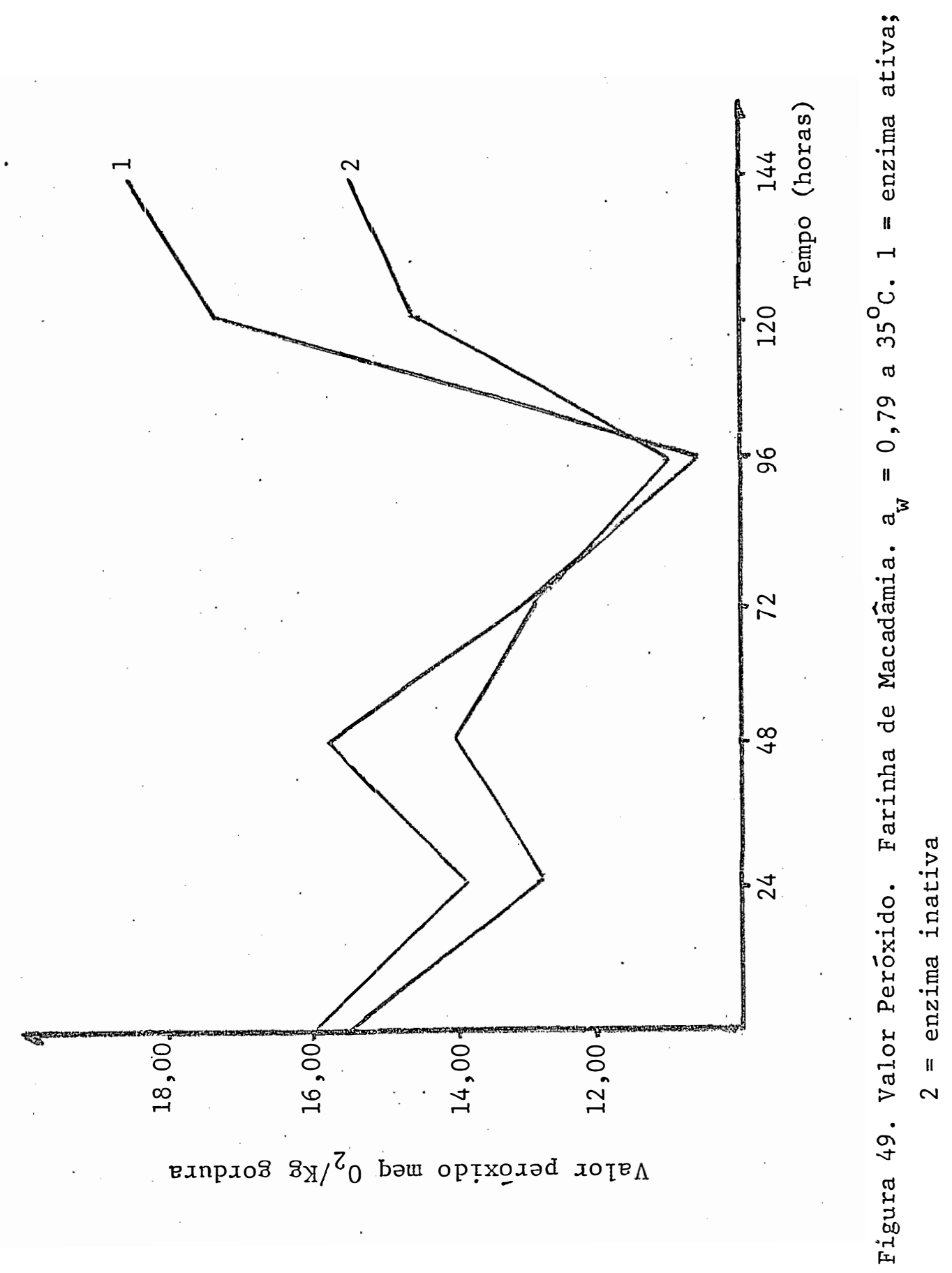




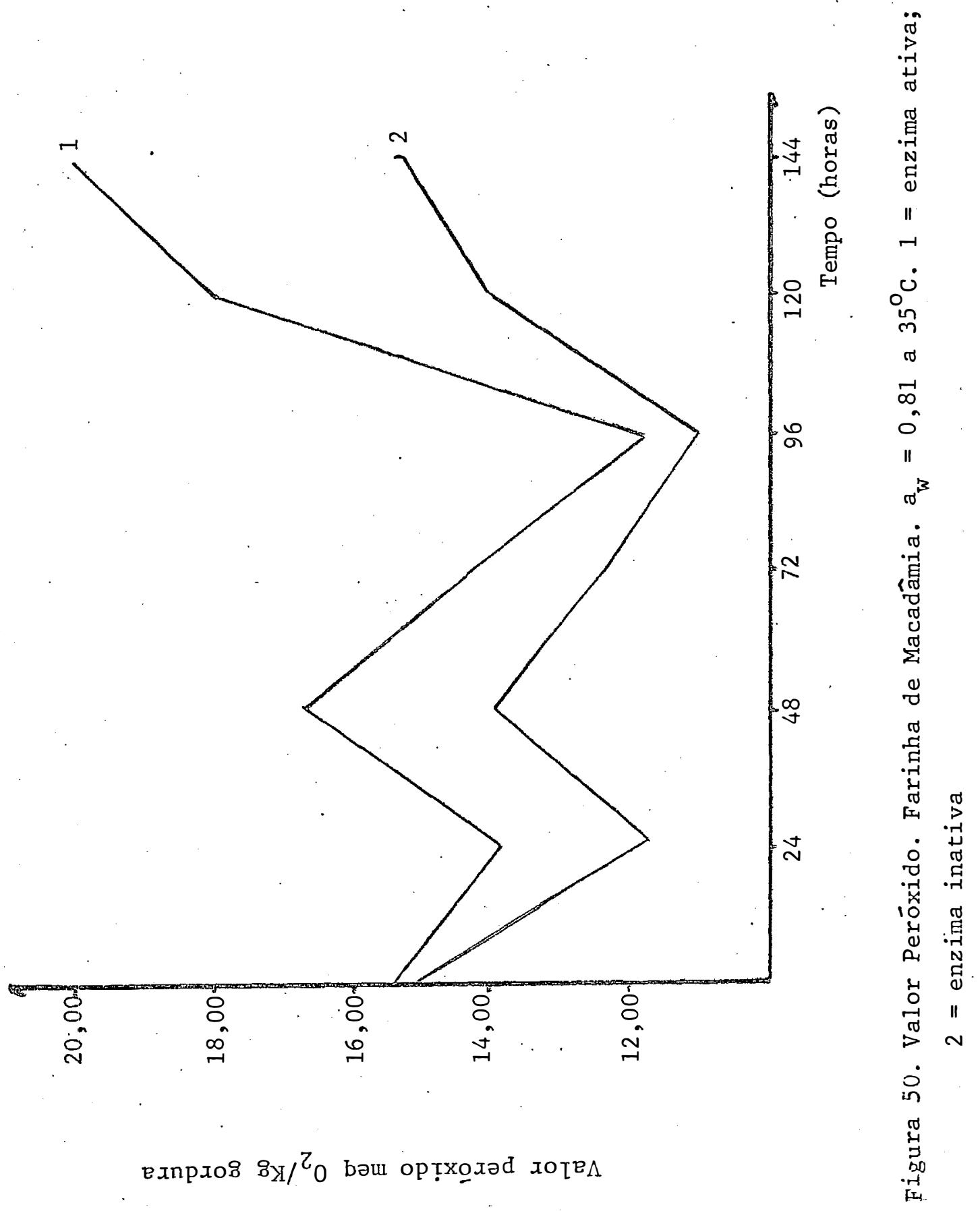




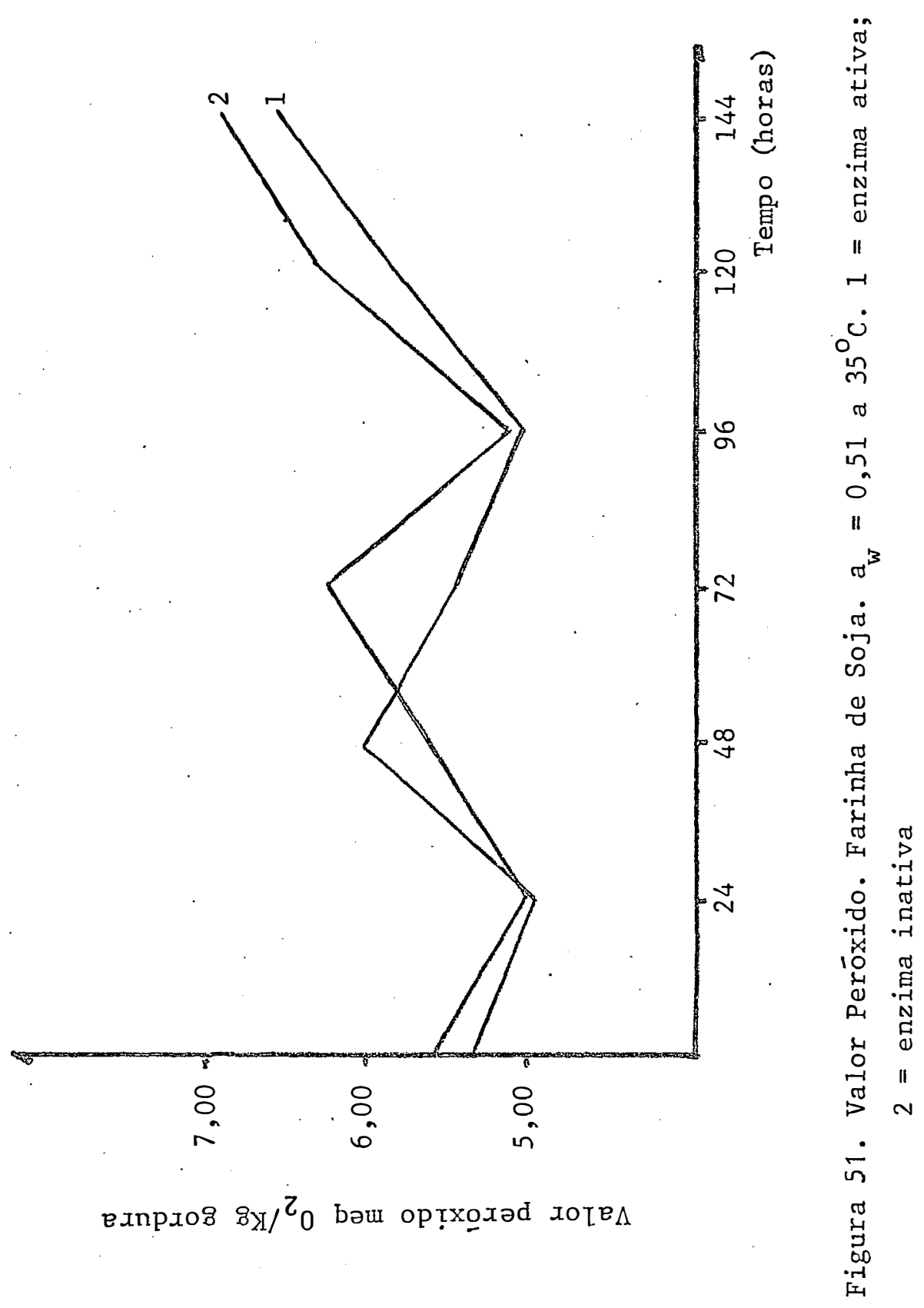




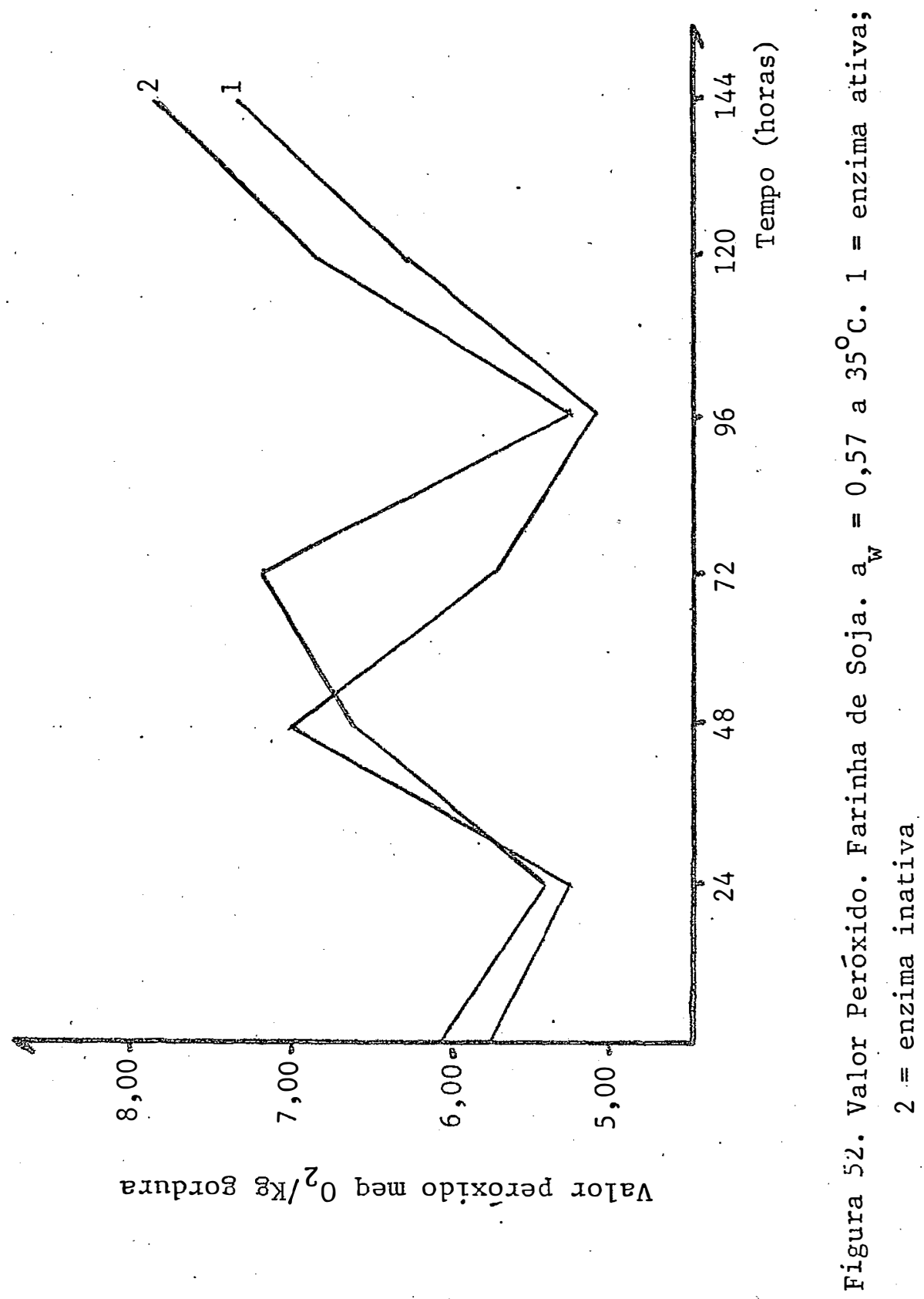




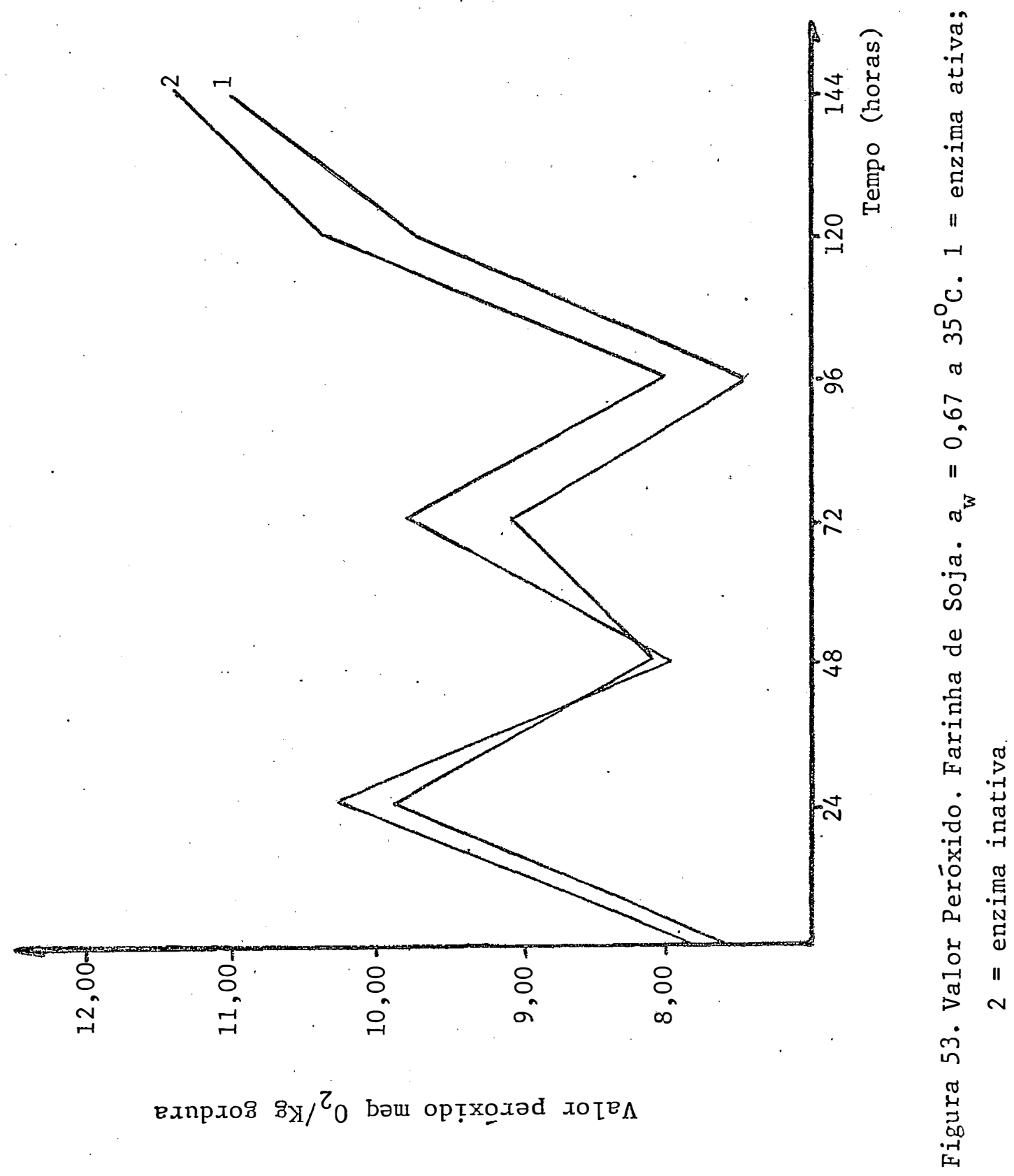




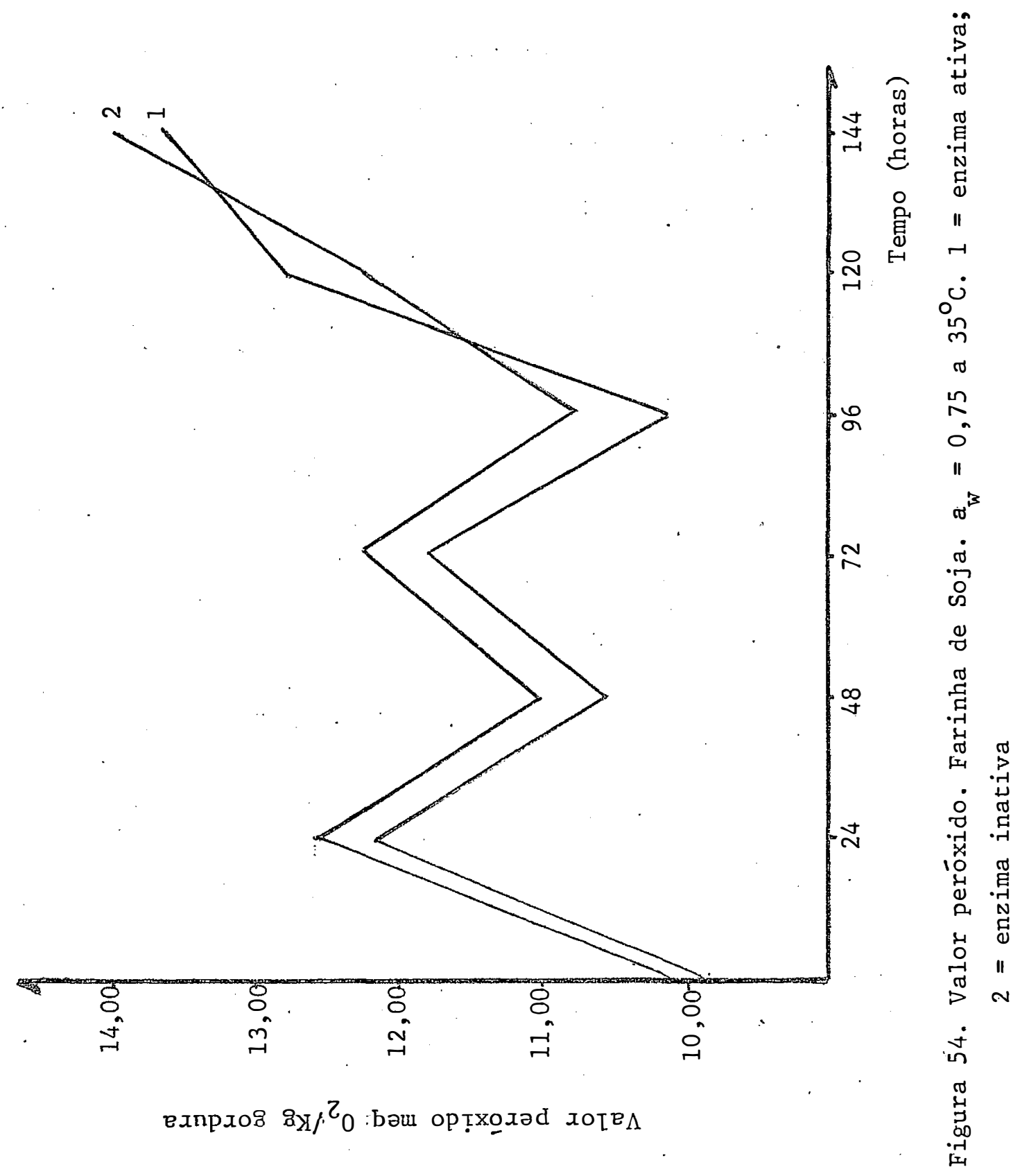




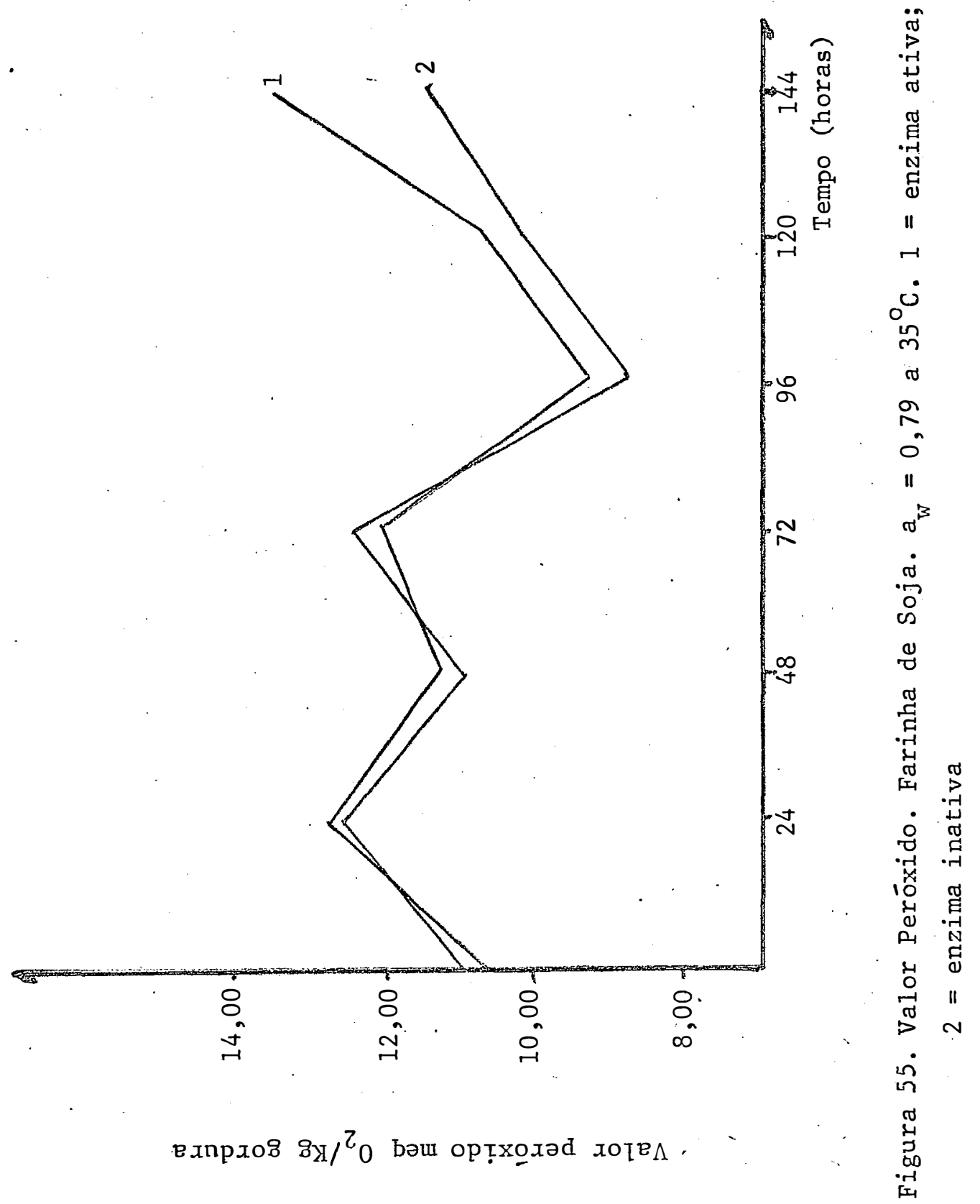




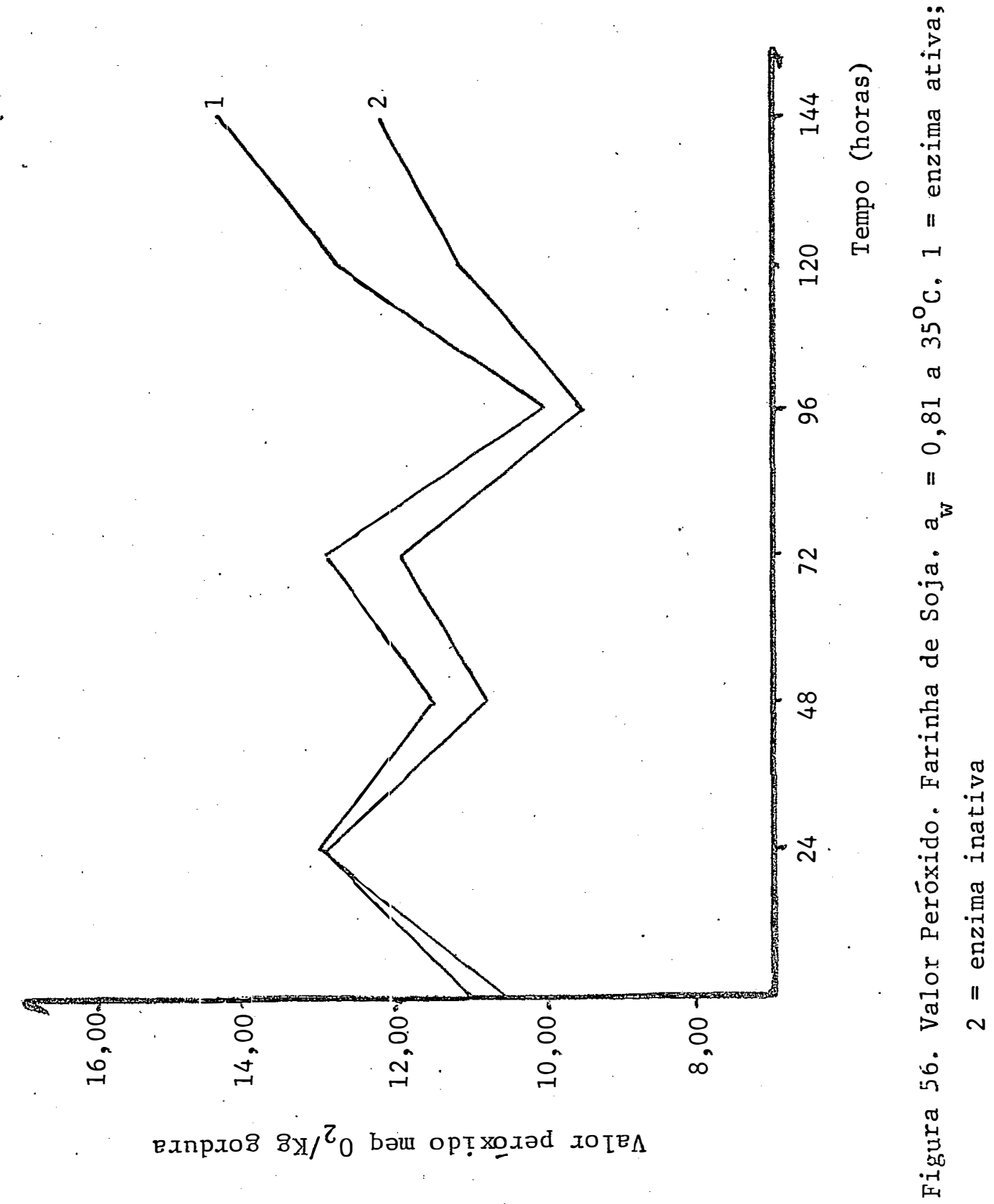


5. DISCUSSÃO DOS RESULTADOS

As Figuras 6 a 32 apresentam os resultados ob tidos nos métodos com recirculação e sem recirculação de ar, para deter minação da umidade relativa de equilíbrio. Como pode ser observado, houve uma redução bastante significativa de tempo, quando o método de ar recirculado foi utilizado, em relação ao método sem recirculação de ar.

Experimentos feitos pelo método sem recirculação de ar, apresentaram também grandes oscilações no peso da amostra antes que o equilíbrio seja alcançado, com consequente aumento no tempo do experimento. Isto porque nestes, não hā equilíbrio no sistema, isto é, a cada passagem o ar deve entrar em equilíbrio com a umidade da solução salina usada, e passar pela amostra, o que leva a dois processos de transferência de umidade.

Durante este processo, quando são usadas soluções salinas com $a_{w}$ suficientemente alta para permitir o desenvolvimento de microrganismos, ocorreu perda do material antes que a umidade relativa de 
equilíbrio fosse alcançada.

No método com recirculação, o ar que passa pelas amostras está constantemente em contato com a solução salina, uma vez que o aparelho funciona em circuito fechado, não apresentando portanto, grandes alterações no equilíbrio da umidade do sistema.

Como o ar recirculado é usado como meio de transporte para a transferência do vapor d'água das soluções salinas para as amostras, este método realmente deve ser mais eficiente, uma vez que permite o estabelecimento de uma atividade de āgua uniforme na corrente de ar em tempo relativamente curto, conforme anteriormente observado por GUR-ARIEH (1965).

Foram realizados inicialmente experimentos com todas as soluções salinas relacionadas na tabela 1 . No método sem recirculação houve o crescimento de microrganismos em $a_{w}$ igual e superior a 0,75 , em consequência do tempo muito longo do experimento. No método de ar recirculado ocorreu aglomeração de partículas de farinha e crescimento de microrganismos; porēm em $a_{w}$ igual e superior a 0,84 .

Estes experimentos demonstraram que o método de ar recirculado possiblita pesquisas em condições de umidade mals elevadas que o método sem recirculação de ar.

Experimentos com soluções salinas com $a_{w}$ igual e superior a 0,84 foram eliminadas do trabalho, uma vez que nestas condições ocorreu perda do material antes do aparecimento de qualquer reação oxidativa. 
As Figuras 33 a 38 , mostram a isoterma de absorção de umidade das farinhas de castanha do pará, macadâmia e soja. Deve ser observado que a absorção de umidade foi diferente para cada farinha, em uma mesma $a_{w}$, isto porque os alimentos possuem caracteristicas próprias, conforme observado por VAN DEN BERG e BRUIN (1981), e $a_{w}$ é uma medida da concentração efetiva da água no alimento.

Ainda nas Figuras 33 a 38 , observa-se que a farinha de semente oleaginosa que apresentou maior capacidade de absorção de umidade foi a soja, em todas as $a_{w}$ estudadas. Em $a_{w}$ entre 0,51 e 0,57, a castanha do pará absorveu maior umidade que a macadâmia, embora nas $a_{w}$ subsequentes a macadâmia tenha tido maior absorção.

Entretanto, como pode ser observado nas Figuras 39 a 56, a castanha do parä, que apresentou menor teor de umidade, âlcançou inaiores indices de valor peróxido que as outras farinhas.

Isto porque são as propriedades físico-químicas da āgua, representadas pela $a_{w}$, mais que o conteudo de umidade, é que determinam que reações ocorrem em um produto alimentício.

Partindo de $a_{w}=1,0$ a diminuição na $a_{w}$ ocasiona um decréscimo na taxa de quase todas as reações químicas deteriorativas, por que para que estas reações ocorram, é necessārio que "água livre" esteja disponível (POTTAST et alii, 1975), aumentando a mobilidade dos reagentes. 
Na oxidação de lipídeos, o teor de umidade tem efeitos diferentes, dependendo do agente catalisador da reação. Como pode ser observado nas Figuras 39 a 56 , a oxidação de 1 ipideos cata1 isada pela enzima lipoxigenase, aumentou com o aumento da $a_{w}$, nas três farinhas de sementes oleaginosas pesquisadas.

Conforme evidenciado por DUCKWORT (1981), os substratos das reações enzímicas devem ser capazes de difundirem até os sítios atị vos das moléculas da enzima ou, reciprocamente, as enzimas devem ser capazes de se aproximarem das moléculas do substrato.

Esta mobilidade das substâncias que vão tomar parte nas reações, resulta em aumento na taxa de reaçao e pode causar rápida deterioração.

Entretanto, quando a enzıma lipoxigenase foi inativada por tratamento térmico, observou-se um aumento no valır. peróxido até $a_{w}=0,75$. Em $a_{w}$ acima deste valor, houve um decréscimo no valor peróxido, que pode ser explicado pelo efeito protetor que a ägua exerce sobre a autoxidação de lipídeos, conforme evidenciado por LABUZA (1970 e 1980) e QUAST e KAREL (1970).

De acordo com estes autores, este efeito pode ser explicado de duas formas: a āgua pode formar pontes de hidrogênio com hidroperóxidos, protegendo-os da decomposição; e, a āgua pode ter efeito direto sobre as radicais livres, aumentando a taxa de reação entre estes radicais e outros compostos, como por exemplo, as proteínas. 
E evidente portanto, que no processo de autoxidação a água atua interferindo nos radicais iniciadores da reação, tornando-os não disponíveis.

GOPALAKRISHNA e PRABHAKAR (1983) observaram que a água, num processo oxidativo, além de afetar as reações primārias, tambēm influencia as reações secundārias da oxidação, que são mais importantes do ponto de vista da aceitabilidade dó consumidor.

As Figuras 39 a 56 também evidenciam que em $a_{w}=0,51$ e 0,57 , as amostras que foram submetidas a inativação enzímica alcançam valor peróxido mais elevado em tempo superior às amos tras que não tiveram sua enzima inativada, conforme evidenciado por BROCKMANN e ACKER (1977a), embora alcancem valor peróxido mais elevado após 6 dịas de armazenagen, em $a_{w}$ atē 0,79 , quando o resultado é invértido.

Observa-se ainda que em $a_{w}$ igual e superior a 0,75 , em todas as farinhas o valor peróxido estā acima do valor máximo eśpecificado pelo Codex Alimentarius Comission.

Valor peróxido elevado è indício de reações oxidativas, que levam a alterações nas características organoléticas, como o aparecimento de sabor amargo, "off flavor" e alterações no valor nutricional dos alimentos.

Um $\mathrm{u} 1$ timo fator a ser considerado, tambēm observado as Figuras 39 a 56, é que o valor peróxidomostra :uma grande variação - em uma mesma $a_{w}$ e mesma farinha de semente oleaginosa 
nos dois processos oxidativos. Esta variação é atribuî́da a formação de produtos secundários da oxidação de lipídeos, conforme evidenciado por BROCKMANN e ACKER (1977c) e KAREL e YONG (1981). 


\section{CONCLUSÕES}

1. 0 método de ar recirculado para determinação da umidade relativa de equilíbrio é mais eficiente que o método sem recirculação de ar, devido a redução do tempo necessärio para a obtenção do equilíbrio.

2. A recirculação do ar permite o trabalho com atividades de água superior àqueles sem recirculação.

3. As farinhas das sementes oḷaginosas castanha do parā, macadâmia e soja diferem na sua capacidade de absorver umidade, sendo que a soja mostrou ter maior capacidade de absorção.

4. A farinha de castanha do parä, embora com menor teor de umidade, teve maior oxidação entre as farinhas estudadas.

5. A oxidação de lipídeos, catalisada por enzimas, aumenta com o aumento da umidade alcançando níveis bastante elevados em . $\mathrm{a}_{\mathrm{w}}=$ 0,79 e 0,81 
6. A autoxidação de lipídeos é favorecida em farinhas com $a_{w}$ entre 0,51 e 0,75 e desfavorecida, isto $\bar{e}$, torna-se muito lenta em farinhas com $a_{w}$ igual a 0,79 e 0,81 .

7. As variações no valor peróxido no decorrer do experimento, ocorrem na mesma proporção, na autoxidação è na oxidação catalisada por enzimas.

8. As farinhas de sementes aeragenosas Castanha do Paráa, Macadâmia e soja armazenadas em atividades de água entre 0,51 e 0,67 estão menos sujeitas a deteriorações oxidativas que farinhas . armazenadas em atividades de água acima destes valores. 
LITERATURA CITADA

ACKER, L., 1962. Enzymic Reactions in Food of Low Moisture Contents. Advances in Food Research. New York, 2:263-330.

ACKER, L., 1969. Water Activity and Enzymic Activity. Food Technology. Chicago, $22(10): 1257-1270$.

ACKER, L. e R.WISSE, 1972. Behaviour of Lipase in Systems of Low water content. II Enzymic 1ipolysis in the Range of Extreme Low water Activity. Zeitschrift fuer Lebensmittel-Untersurchung und Forschung. Munich, $150(4): 205-211$.

ASAKAWA, T. e M.SETSURO, 1978. Deteriorations of Lipids and Proteins in dried Foods During Storage. Eiyo to Shokuryo. Tokyo. 31(6):55764. Apud Chemical Abstracts, $91: 191630$ s. 1979. 
BROCKMANN, R. e L.ACKER, 1977(a). The Behaviour of Lipoxygenase in Systems of Low water Content. I. Influence of Water Activity on the Enzymic Oxidation of Lipids. Lebensmittel Wissinschaft Technologie. Zurich, $10(1): 24-27$.

BROCKMANN, R. e L.ACKER, 1977(b). The behaviour of Lipoxygenase in Systems of Low water Content. II. Investigation of reactions products of enzymatic lipid oxidation. Lebensmittel Wissinschaft Technologie. Zurich, $10(6): 322-336$.

CAVALETO, C.; A.DELA CRỤZ; E.ROSS e H.Y.YAMAMOTO, 1966. Factors Affecting Macadamia Nut Stability. I. Raw Kernels. Food Technology. Chicago, 20(8): 108 .

COSTA, S.I.; E.E.MIYA e J.T.FUJITA, 1974. Composição Química e Qualidades Organoléticas e Nutricionais das Principais Variedades de Soja cultivadas no Estado de São Paulo. Coletânea do Instituto de TecnoZogia de AZimentos. Campinas, 5:305-319.

DRAPON, R., 1972. Reactions 'Enzymatiques en Milieu Peu Hydraté. Annales of Technologie Agricole, Paris, 21(4):487-499.

DUCKWORTH, R.B., 1981, Solute Mobility in Relation to Water Content and Water Activity. In: ROCKLAND, L.B. e G.F.STEWART, ed. Water Activity: Influences on Food Quality. London, Academic Press, p.295-317. 
GAL, S., 1975. Recent Advances in Techniques for the Determination of Sorption Isothermes. In: DUCKWORT, R.B. ed. Water Relations of Foods. London, Academic Press, p.139-154.

GARDNER, H.W., 1975. Decomposition of Linoleic acid Hydroperoxides . Enzymic Reactions compared with nonenzymic. Journal of Agricultural and Food Chemistry. Easton, 23(2):129-36.

GOLDOUSKII, A.M. e E.U.IVANOVA, 1979. Effect of 1ypase and Lipoxygenase of seeds under different water content. Pishch. Teknol. 6:123-4. Apud Chemical Abstraçts, 92:1272034. 1980.

GOPALAKRISHNA, A.G. e J.V.PRABHAKAR, 1983. Effect of Water Activity on Autoxidation of Raw Peanut oil. Journal of the American Oil Chemist's Society. Chicago, 60(5):968-970.

GRIMWOOD, B.E., 1971. The Processing of Macadamia Nuts. London, Tropical Products Institute. 66p.

GUR-ARIEH, C.; A.I.NELSON; M.P.STEINBERG e L.S.WEI, 1965. A Method for Rapid Determination of Moisture - Adsorption Isotherms of Solid Particles. Journal of Food Science. Chicago, 30(1):105-110.

HYMOWITZ, T.; F.I.COLLINS; J.PANCZNER e W.M.WALKER, 1972. Relationship beetween the content of oil, Protein and sugar in Soybean. Agronomy Journal. Madison, 64:613-616. 
KAREL, M. e S.YONG, 1981. Autoxidation Initiated Reactions in Foods. In: ROCKLAND, L.B. e G.F.STEWART, ed. Warter Activity: Influences on Food Quality. London, Academic Press, p.511-529.

KARMAS, E.R., 1973. Symposium Water in Biosystems. Journal of Food Science. Chicago, 38:736-739.

KELLOR, R.L., 1974. Defatted Soy Flour and Grits. Journal of the American Oil Chemist's Society. Chicago, 51(1):77-80.

LABUZA, T.P., 1968. Sorption Phenomenon of Food. Food Technology. Chicago, $22(3): 15$.

LABUZA, T.P.; S.R.TANNENBAUM e M.KAREL, 1970. Water content and Stability of low moisture and Intermediate Moisture Foods. Food Technology. Chicago, 24(5):35-42.

LABUZA, T.P.; L.McNALLY, D.GALLAGHER, J.HAWKES e F. HURTADO, 1972 . Stability of Intermediate Moisture Foods. 1. Lipid Oxidation. Journal of Food Science. Chicago, 37(1):154-9.

LABUZA, T.P., 1980. The Effect of Water Activity on Reaction Kinetics of Food Deterioration. Food Technology. Chicago, 34(4):36-41.

LABUZA, T.P., 1982. Moisture Gain and Loss in Packaged Foods. Food Technology. Chicago, 36(4):92-97. 
LONCIN, M.; J.J.BIMBENET e J.LENGES, 1968. Influence on the activity of water on the Spoilage of Foodstuffs. Joumal Food Technology. Oxford, 3:131-142.

MENEZES, J.J.B., 1967. A Castanha do Parā na Indūstria de Alimentos. Boletim do Instituto de Tecnologia de Alimentos. Campinas, 9:23-30.

MEYER, L.H., 1975. Food Chemisty. Westport, The A.V.I. Publishing, $385 p$.

MUSTAKAS, G.C.; W.J.ALBRECHT; J.E.MCGHEE; L.E.BLACK; G.M. BOOKWALTER e E.L.GRIFFIN Jr., 1969. Lipoxydase Deactivation to Improve Stability, Odor and flavor of Full Fat Soy Flours. Joumal of the American Oil Chemist's Society. Chicago, 46(11):623-626.

OLIVEIRA, A.J.; L.E.GUTIERREZ; G.D.OLIVEIRA e P.R.CANTARELLI, 1980. Características Químicas e Composição do óleo e da Torta da Semente de Nogueira Macadâmia. Boletim da Sociedade Brasileira de Ciência e Tecnologia de Alimentos. Campinas, 52:20-27.

POTTHAST, K.; R.HAMM e L.ACKER, 1975. Enzymic Reactions in Low Moisture Foods. In: DUCKWORTH, R.B. ed. Water Relations of Foods. London, Academic Press. p.365-377.

PRICHAVUDHI, K. e H.Y.YAMAMOTO, 1965. Effect of Drying Temperature on Chemical Composition and Quality of Macadamia Nuts. Food Technology, Chicago, $19(7): 129-132$. 
QUAST, D, e M.KAREL, 1972. Effects of Environmental Factors on the oxidation of potato chips. Journal of Food Science. Chicago, 37 (4) $: 584-88$.

ROCKLAND, I.B., 1969, Water Activity and Storage Stability. Food Technology. Chicago, 23(10):1241-1251.

ROCKLAND, L.B. e NISHI, 1980. Influence of Water Activity on food Product Quality and Stability. Food Technology. Chicago, 34(4): 42-51.

schmitz, C.M., 1969. A Soja na Alimentacão Humana. s.l., Universidade Federal de Santa Maria e Instituto Nacional de Desenvolvimentto Agrärio. $45 \mathrm{p}$.

SCHWIMMER, S,, 1980. Influence of Water Activity on Enzyme Reactivity and Stability. Food Technology. Chicago, 34(5):64-74.

SHEMER, M.; L.S.WEI e E.G.PERKINS, 1973. Nutritional and Chemical Studies of Tree Processed Soybean Foods, Journal of Food Science, Chicago, $38: 112-115$.

SMITH, A.K. e S.J.CIRCLE, 1972, Soybeans: Chemistry and Technology. Westoport, The AVI Publishing. 470p.

SMITH, P.R., 1971. The Determination of Equilibrium Relative Humidity or Water Activity in foods. A Literature Review. Scientific. and Technical Survey. B.F.M.I.R.A., no 70, March 29 p. 
STINE, C.M.; H.A.HARLAND; S.T.COULTER e R.JENNESS, 1954. A Modified Peroxide Test for Detection of Lipid Oxidation in Dairy Products. Journal of Dairy Science. Champaign, 37(2):202.

TROLLER, J.A., 1980. Influence of Water Activity on Microorganisms in foods. Food Technology. Chicago, 34(5):76.

VAN DEN BERG, C. e S.BRUIN, 1981. Water Activity and its Estimation in Food Systems: Theoretical Aspects. In: ROCKLAND, L.B. e G.F.STEWART, ed. Water Activity: Influences on Food Quality. London, Academic Press, p.1-61.

WILKENS, W.F.; L.R.MATTICK e D.B.HAND, 1967. Effect of Processing Method on Oxidative off Flavors of Soybean Milk. Food Technology. Chicago, 21(12):86-89.

ZANGELMI, A.C.B.; M.A.TAGLIOLATTO; E.L.DIAS e D.A.LANGE, s.d. Produtos de Soja: Leite, Farinha e Outros. São Paulo, Secretaria da Indústria e Comércio. 157p. (Série Tecnologia Agroindustrial, 10). 
A P E N D I C E 

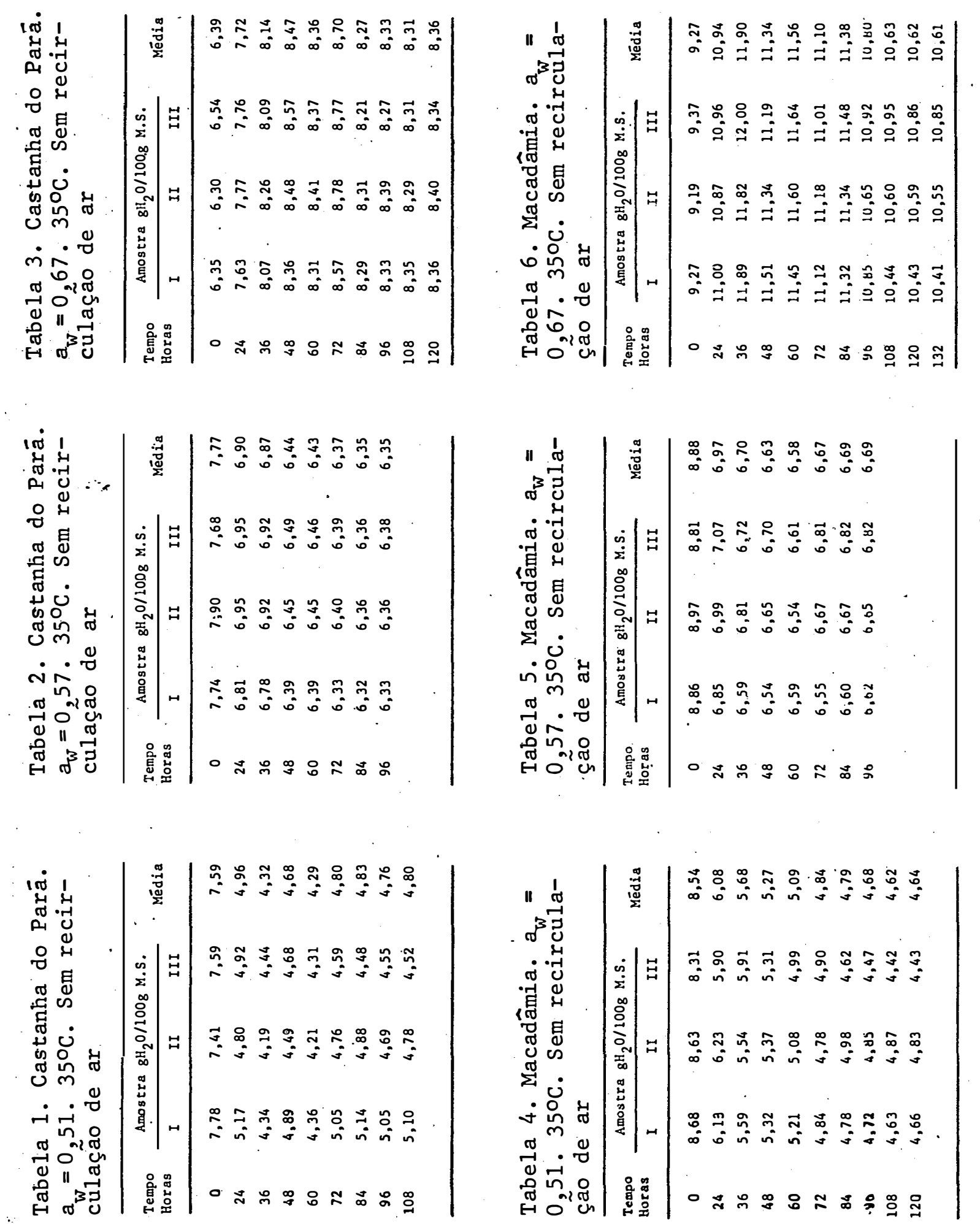


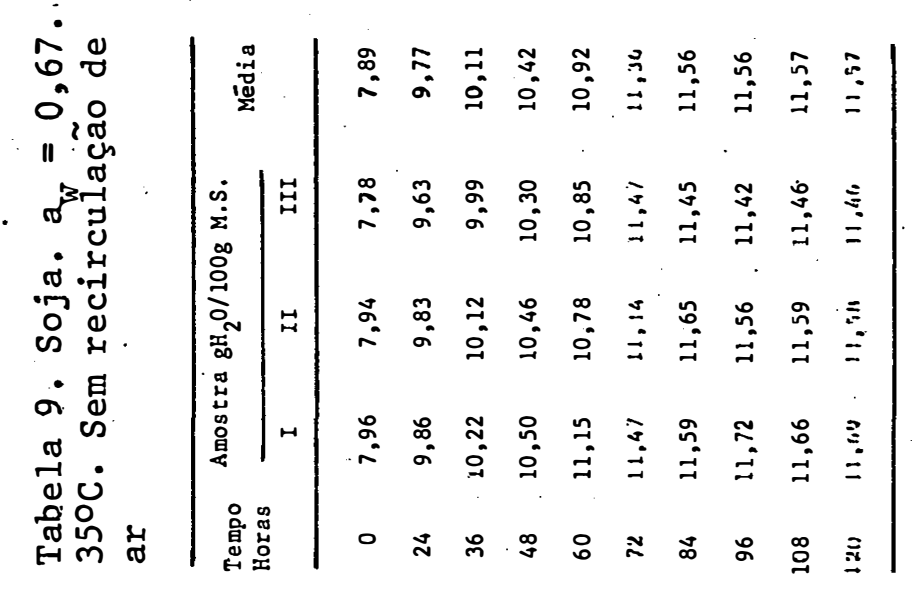

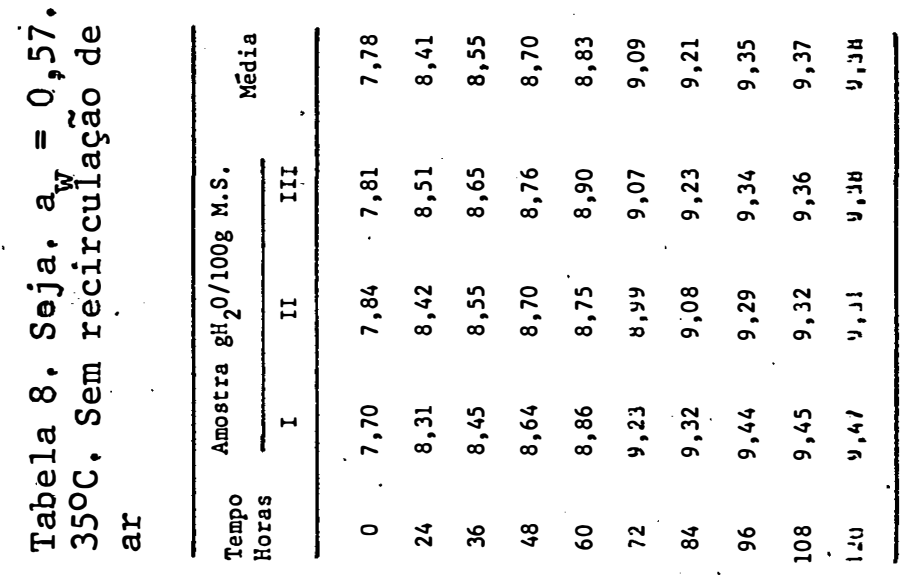

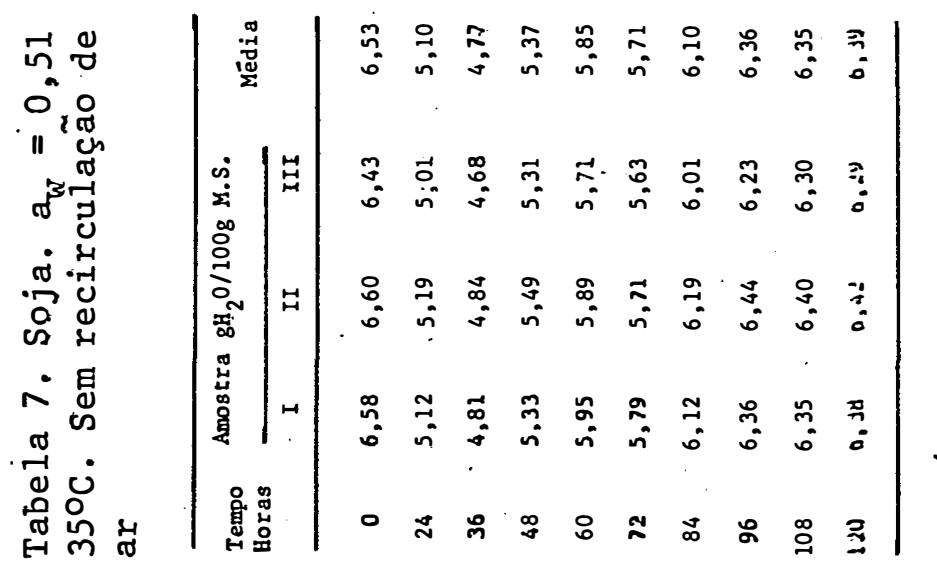



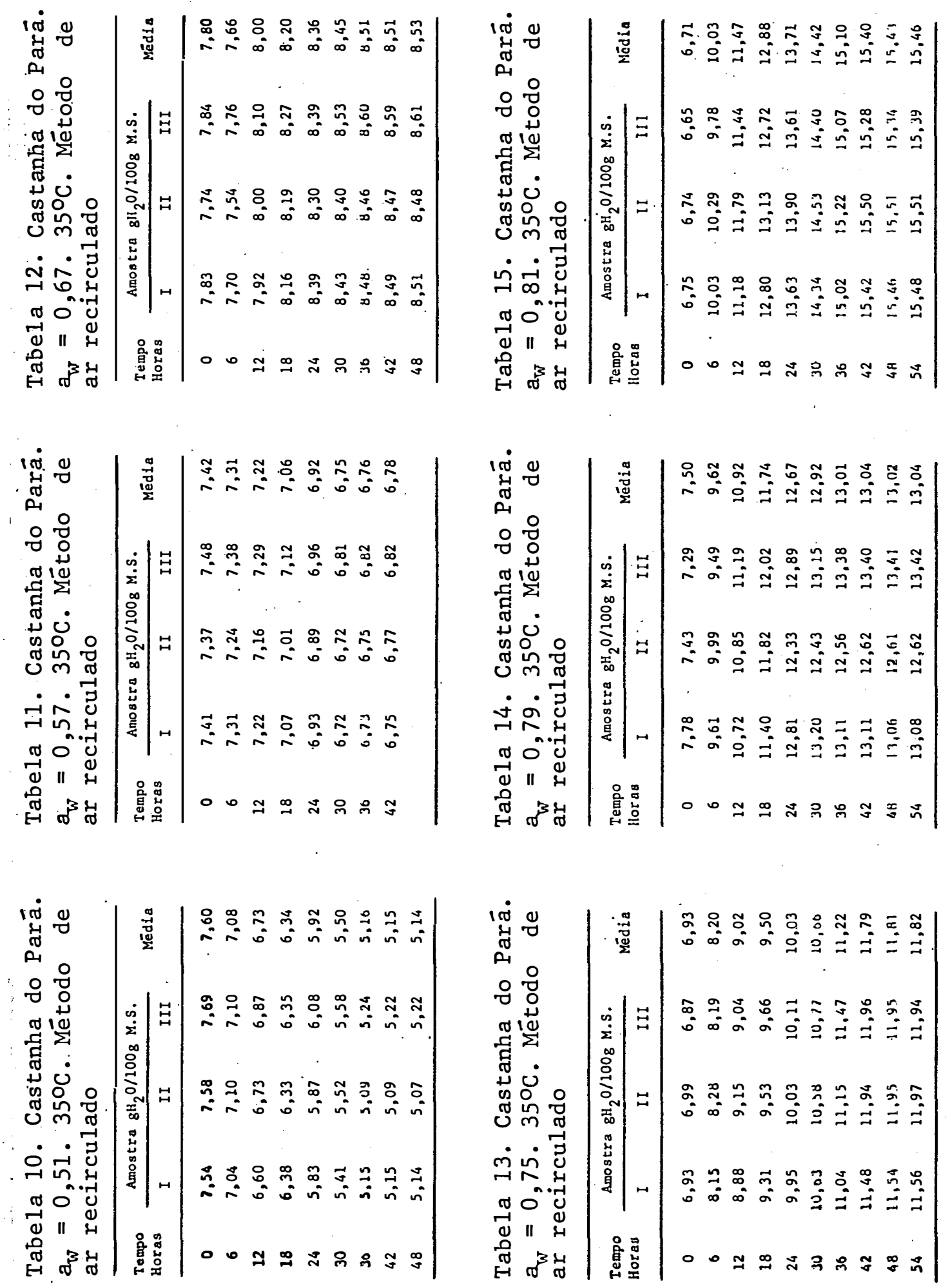

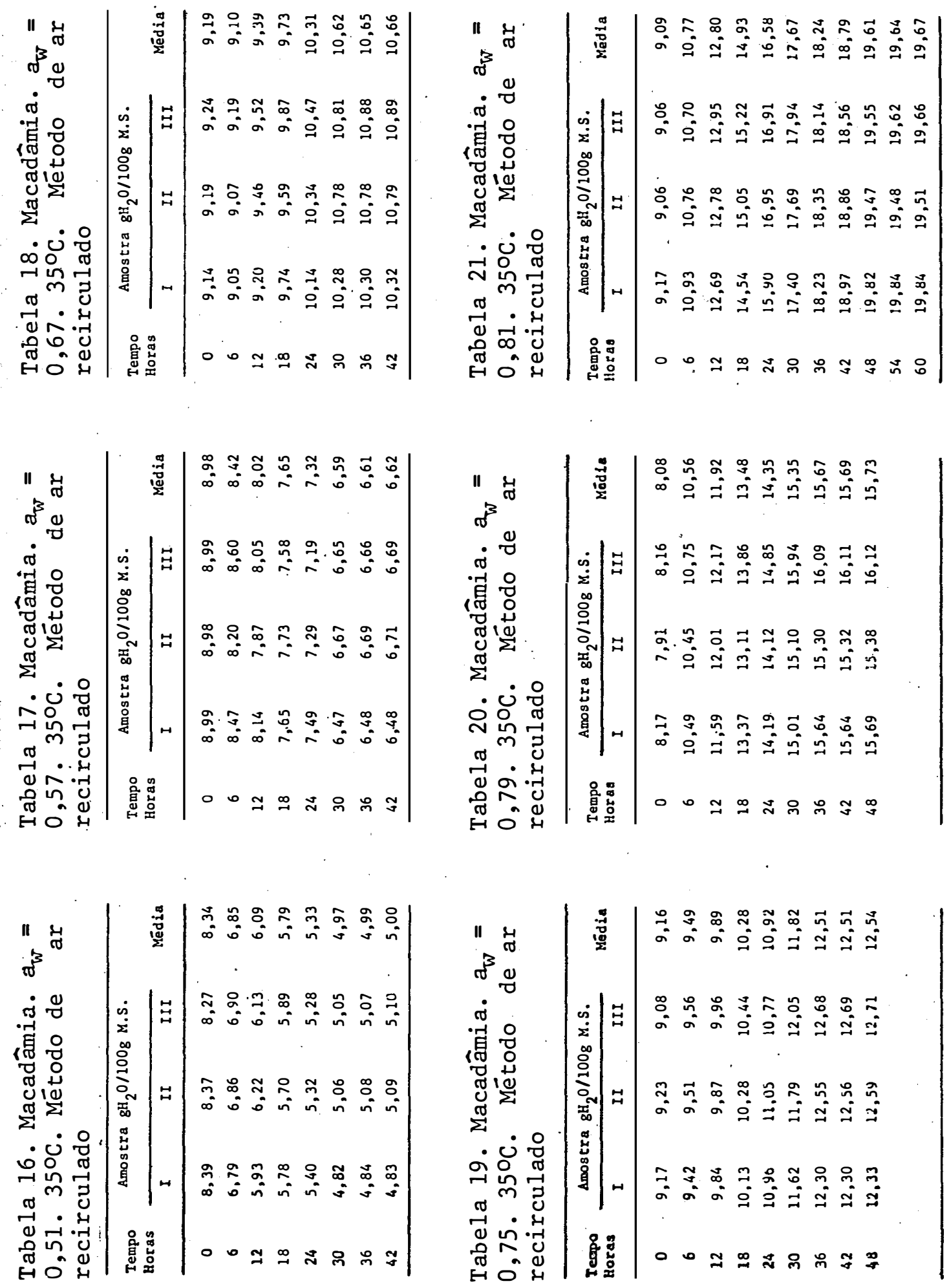

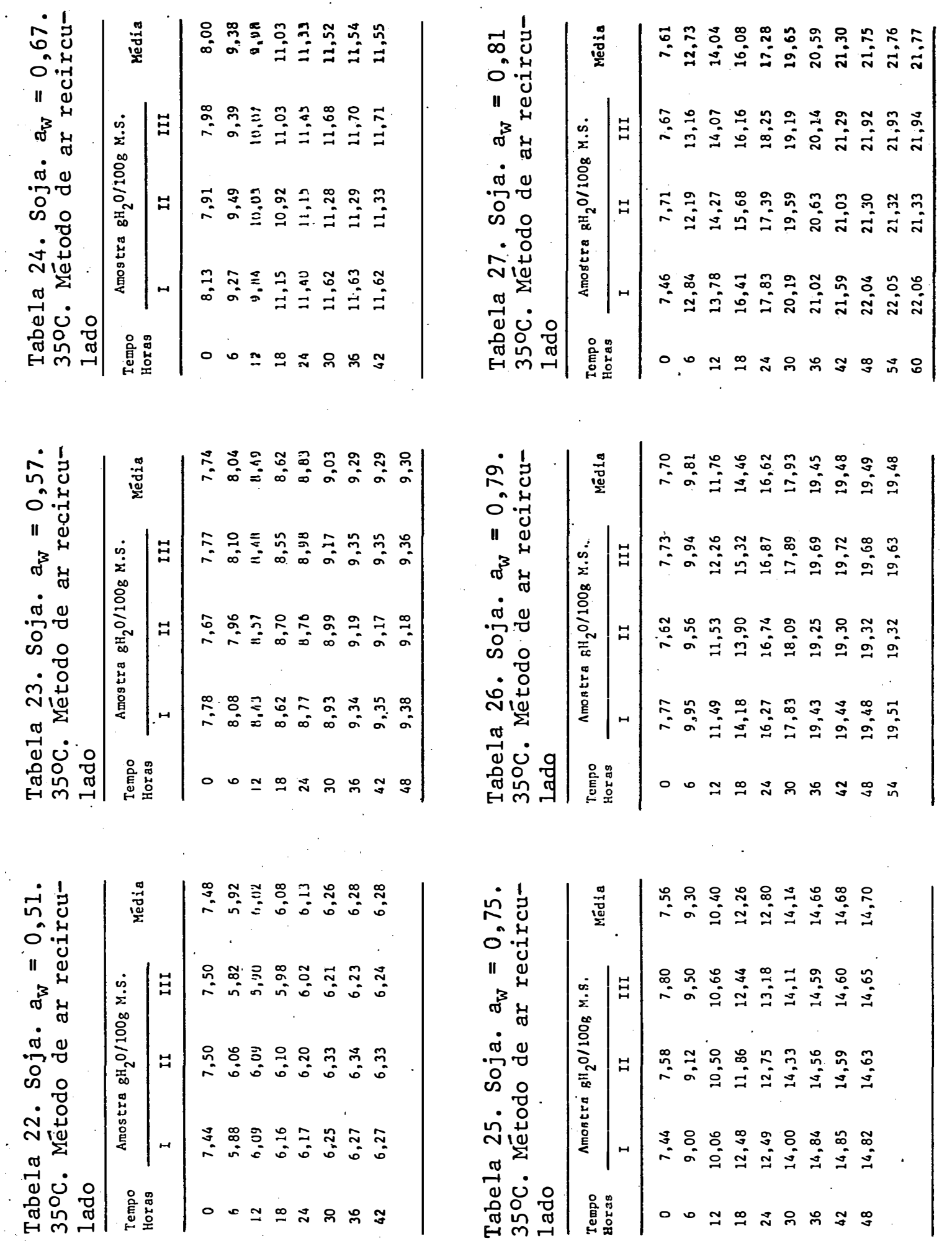


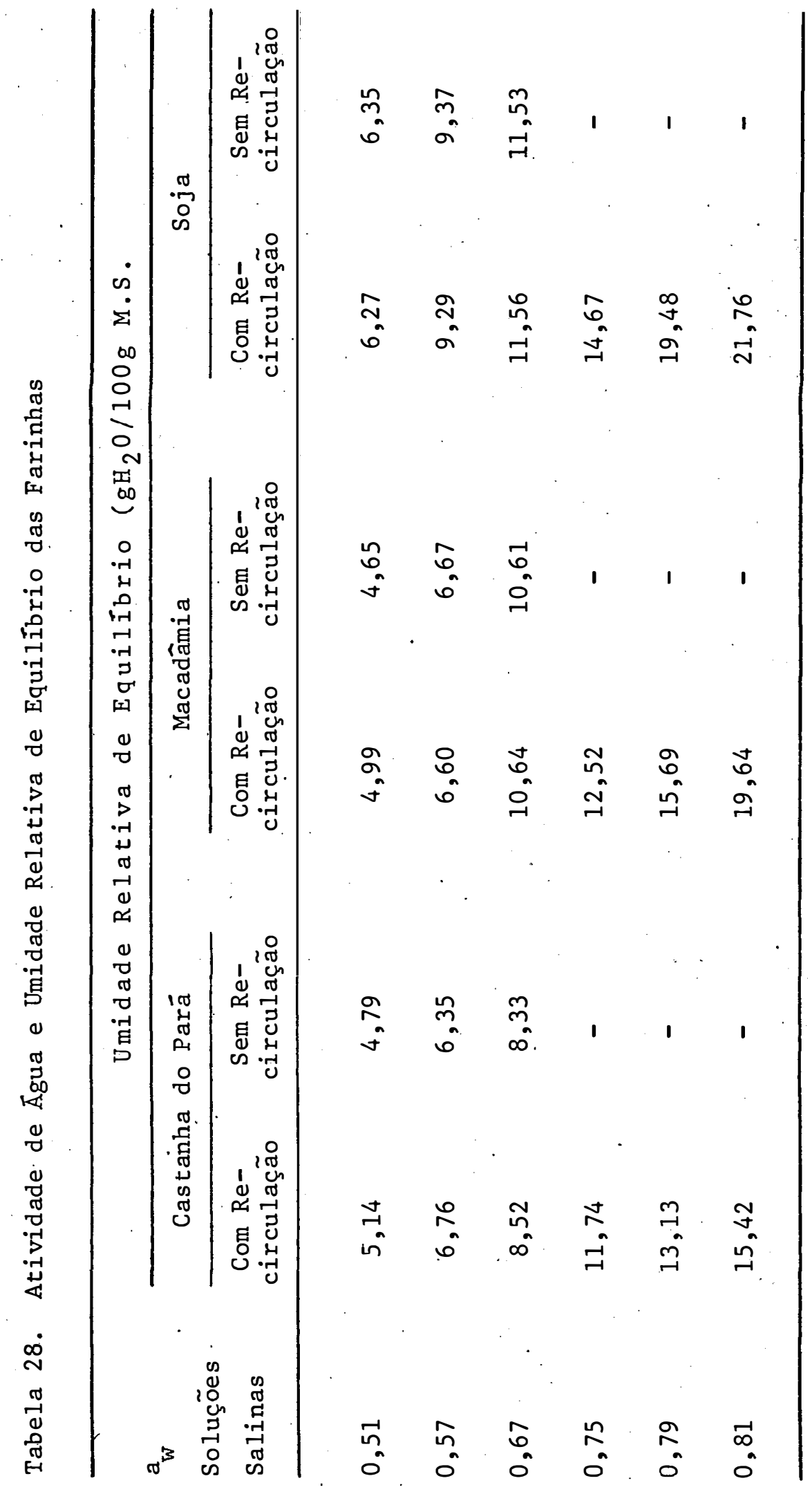



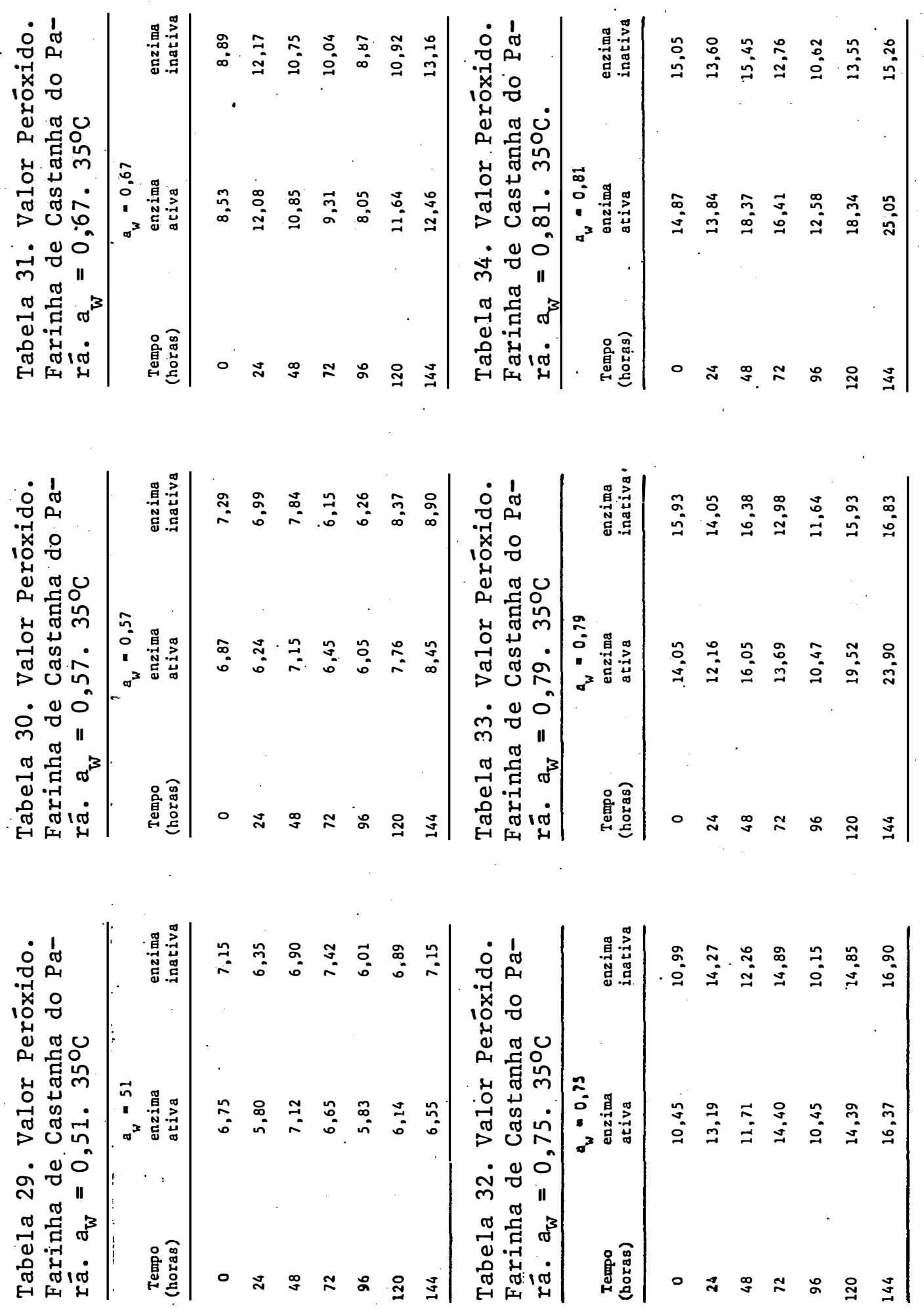

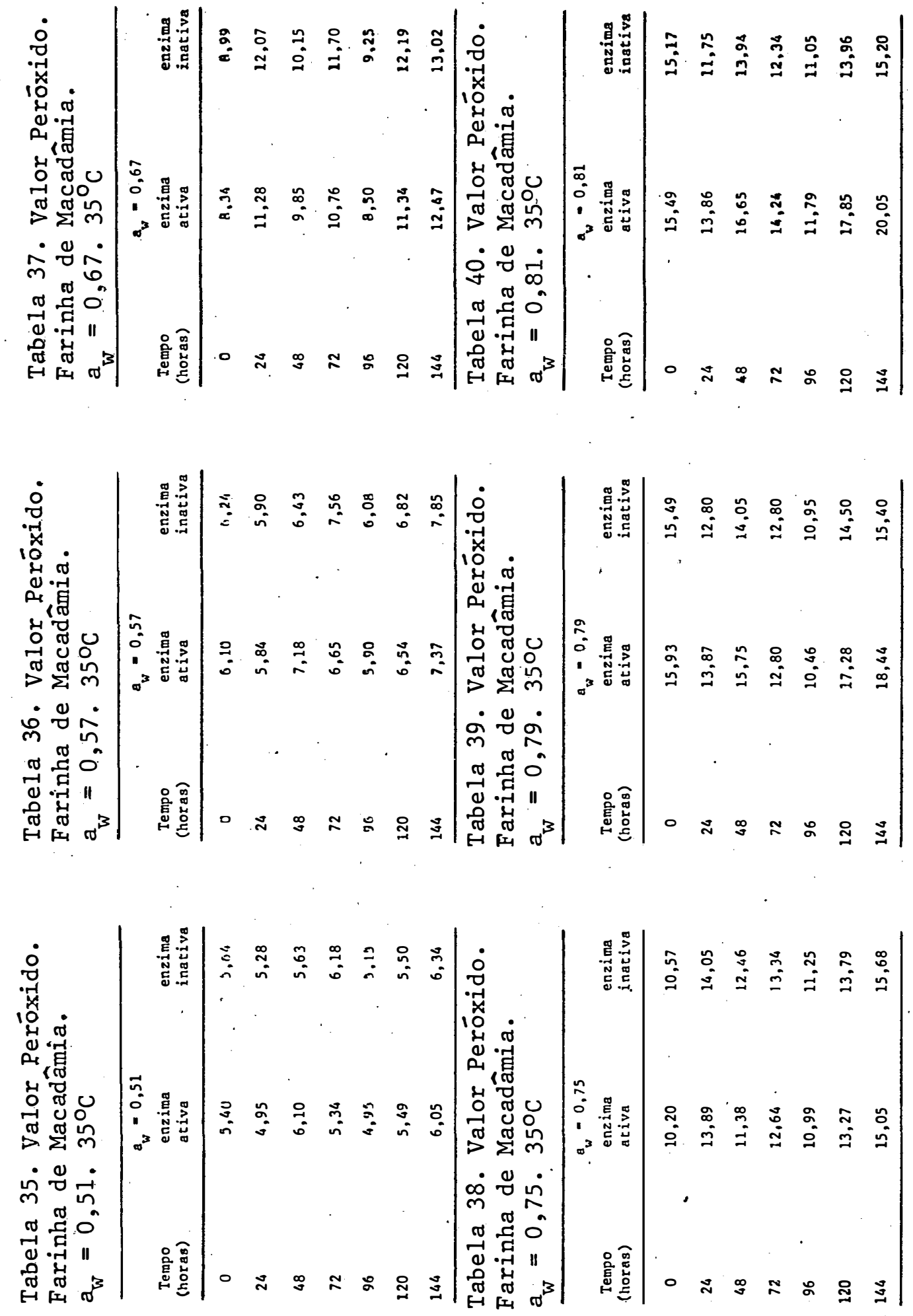


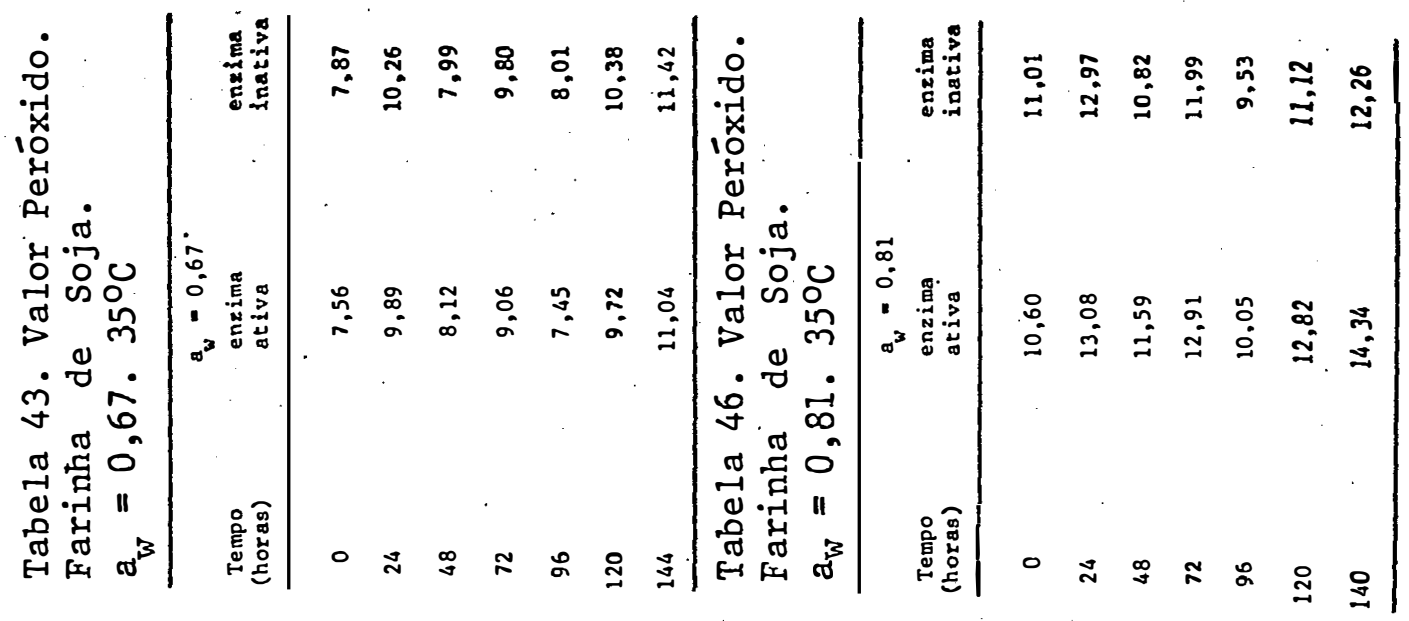

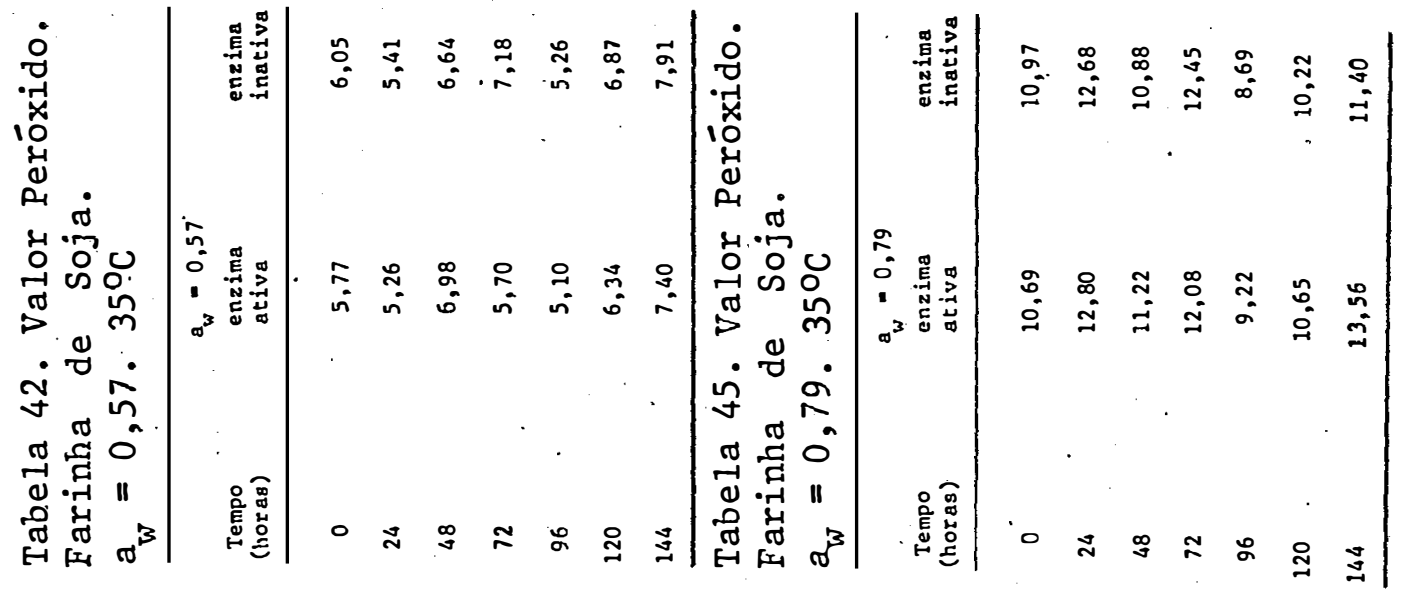

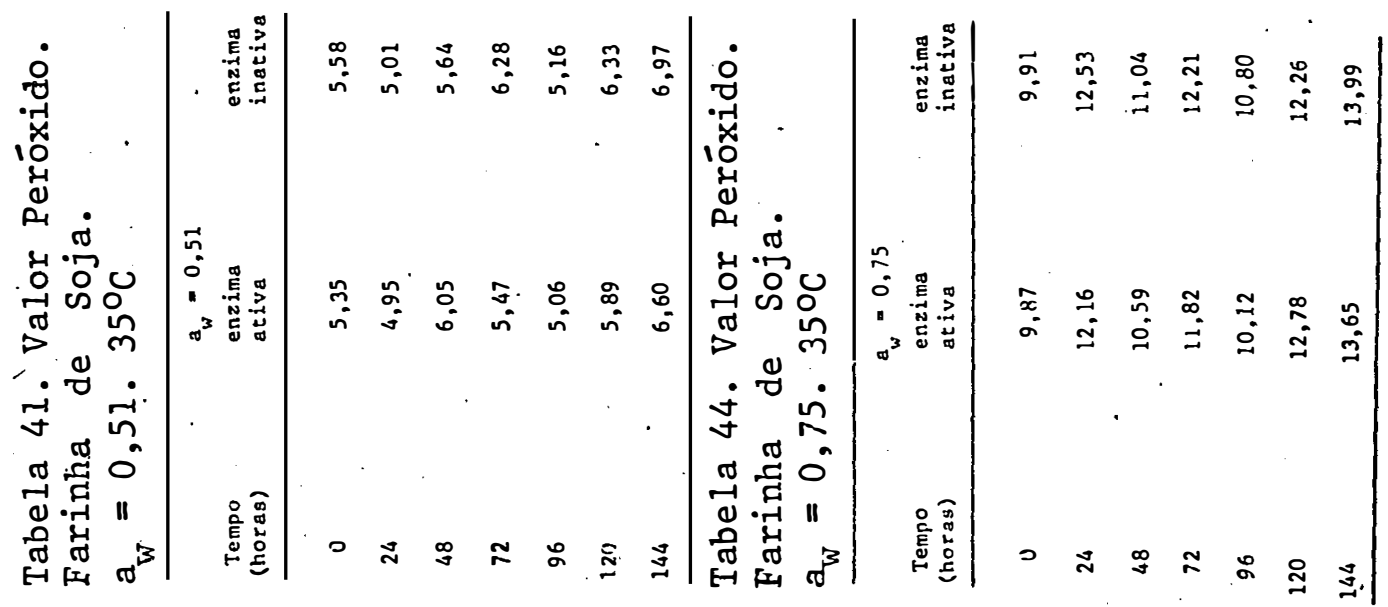

